\title{
Normas Primárias e Secundárias do Setor de Telecomunicações - 2011
}

\section{Statutes and Administrative Regulations of the Telecommunication Sector}

\author{
Organizadores \\ Márcio lorio Aranha (Direito) \\ João Lima (Ciência da Informação) \\ Laura Lira (Coordenação de Catalogação)
}

Coleta e Tratamento de Dados

Renata Tonicelli de Mello Quelho 


\section{Sumário}

Lista de Abreviaturas e Siglas ............................................... 309

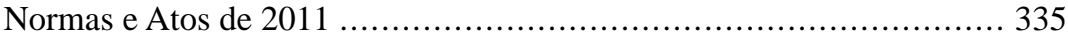

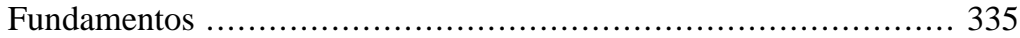

Aspectos Históricos ............................................ 335

Infraestrutura e Recursos do Setor de Telecomunicações .............. 335

Equipamentos de Telecomunicações ................................. 335

Antenas ............................................................ 335

Estações de Telecomunicações ..................................... 335

Certificação / Homologação .......................................... 335

Espectro de Radiofrequência ..................................... 336

Atribuição, Destinação e Designação de Radiofrequência ........... 336

Condições de Uso de Radiofrequência e Canalização (Distribuição de Canais) ......................................................... 336

Órbita e Satélite .......................................................... 336

Administração do Setor de Telecomunicações ......................... 337

Fiscalização das Telecomunicações ................................... 337

Liberdade de Participação ....................................... 338

Tributação no Setor de Telecomunicações .............................. 338

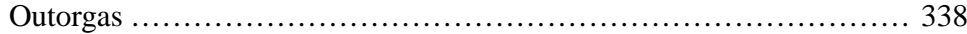

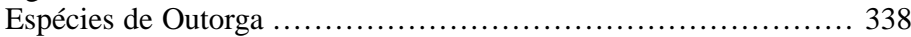

Concessão (regras aplicáveis) .............................. 338

Planos de Serviços ................................................ 340

Políticas de Telecomunicações .......................................... 340

Política Tarifária ................................................. 340

Política Industrial .............................................. 341

Concorrência no Setor de Telecomunicações .......................... 341

Universalização e Massificação ......................................... 342

Acesso às Telecomunicações ........................................ 342

Educação e Pesquisa ............................................... 343

Metas de Universalização ........................................ 343

Pesquisa \& Desenvolvimento ...................................... 343

Qualidade do Serviço ................................................. 343

Controle Social, Hierárquico e Interorgânico .......................... 344

Sigilo em Telecomunicações .......................................... 344

Convergência ................................................... 345

Classificações de Serviços no Setor de Telecomunicações ............. 345

Quanto ao Regime Jurídico de Prestação ................................ 345

Serviço Prestado em Regime Público ............................. 345

Quanto ao Gênero ................................................ 345

Serviço Limitado ..................................................... 345

Serviço Limitado Privado ............................................. 345

Serviço de Valor Adicionado ........................................ 345

Quanto à Perspectiva Convergente ................................. 346 
Comunicação Multimídia ..................................... 346

Comunicação de Massa ....................................... 346

Serviços no Setor de Telecomunicações ................................ 346

Serviço Telefônico Fixo Comutado (STFC) ........................ 346

Serviço Móvel Pessoal (SMP) .................................... 349

Serviço de Comunicação Multimída (SCM) ........................ 349

TV a Cabo .................................................... 349

TVA (Serviço Especial de TV por Assinatura) ...................... 350

DTH (Direct to Home - Serviço de Distribuição de Sinais de Televisão e de Áudio por Assinatura Via Satélite) ............................ 350

MMDS (Multichannel Multipoint Distribution Service - Serviço de

Distribuição de Sinais Multiponto Multicanal) ...................... 351

Serviço Rádio do Cidadão ......................................... 351

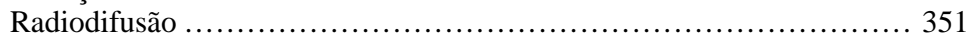

Radiodifusão Comunitária .................................... 352

Serviço Auxiliar de Radiodifusão e Correlatos (SARC) ............. 353

Serviço de Radiotáxi ......................................... 353

Serviço Móvel Marítimo ......................................... 353

Serviço Limitado Privado ......................................... 353

Serviço de Telefonia Rural ....................................... 354

Serviço de Acesso Condicionado .................................. 354

Ramos Jurídicos Afins ............................................ 354

Direito do Consumidor ......................................... 354

Direito da Concorrência ............................................ 354

Direito Administrativo ............................................ 355

Aplicações de Telecomunicações .................................... 355

Aplicações Educacionais ....................................... 355

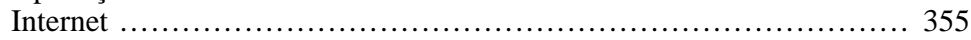

Acesso a Serviços de Interesse Público e Uso de Radiofrequência por tais

Serviços ......................................................... 356

Banda Larga ................................................ 356

Atores no Setor de Telecomunicações ................................ 357

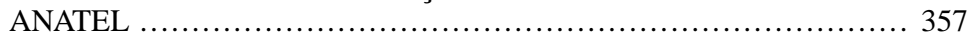

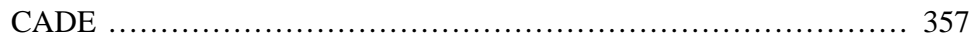

Poder Executivo ............................................... 358

Presidência da República ..................................... 358

Ministério da Justiça .......................................... 358

Ministério das Comunicações ................................. 358

Prestadora / Operadora ........................................... 359

Usuário / Consumidor ............................................... 360

ANCINE ..................................................... 361

Normas Referenciadas ............................................. 361

Lei Ordinária ................................................... 361

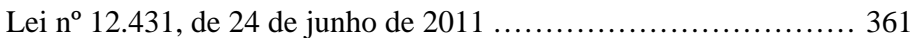

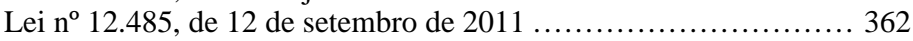

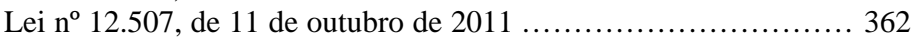




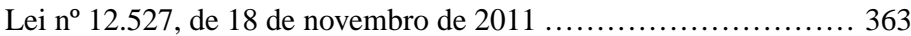

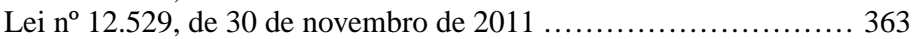

Decreto .................................................... 364

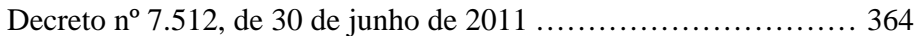

Decreto $\mathrm{n}^{\mathrm{o}} 7.628$, de 30 de novembro de $2011 \ldots \ldots \ldots \ldots \ldots \ldots \ldots . \ldots . \ldots . \ldots 364$

Portaria Ministerial .............................................. 364

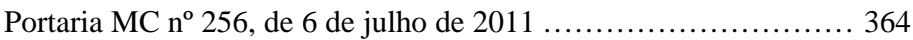

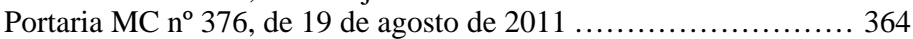

Portaria MC no 420, de 14 de setembro de $2011 \ldots \ldots \ldots \ldots \ldots \ldots . \ldots . \ldots 365$

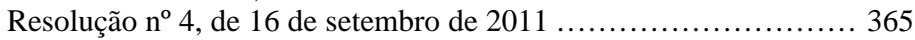

Portaria MC n ${ }^{\circ} 462$, de 14 de outubro de $2011 \ldots \ldots \ldots \ldots \ldots \ldots \ldots . \ldots . \ldots . \ldots 365$

Portaria MC n ${ }^{\circ}$ 69, de 17 de março de $2011 \ldots \ldots \ldots \ldots \ldots \ldots \ldots . \ldots . \ldots . \ldots . \ldots 5$

Portaria MC n ${ }^{\circ} 491$, de 23 de novembro de $2011 \ldots \ldots \ldots \ldots \ldots \ldots . \ldots . \ldots 366$

Portaria MC no 498, de 5 de dezembro de $2011 \ldots \ldots \ldots \ldots \ldots \ldots \ldots . . \ldots . \ldots 366$

Portaria MC n ${ }^{\circ} 561$, de 22 de dezembro de $2011 \ldots \ldots \ldots \ldots \ldots \ldots . \ldots . \ldots 367$

Resolução ...................................................... 367

Resolução da ANATEL n ${ }^{\circ} 560$, de 21 de janeiro de 2011 ........... 367

Resolução da ANATEL no 561 , de 28 de janeiro de 2011 ........... 368

Resolução da ANATEL n ${ }^{\circ} 562$, de 9 de fevereiro de 2011 ........... 368

Resolução da ANATEL n ${ }^{\circ} 563$, de 30 de março de 2011 ............ 369

Resolução da ANATEL n ${ }^{\circ} 564$, de 20 de abril de 2011 .............. 369

Resolução da ANATEL no 565, de 26 de abril de 2011 .............. 369

Resolução da ANATEL n ${ }^{\circ} 567$, de 24 de maio de 2011 ............ 370

Resolução da ANATEL n ${ }^{\circ} 568$, de 15 de junho de 2011 ............ 370

Resolução da ANATEL n ${ }^{\circ} 569$, de 5 de agosto de 2011 ............ 370

Resolução da ANATEL $n^{\circ} 570$, de 22 de agosto de $2011 \ldots \ldots \ldots \ldots . . . .371$

Resolução da ANATEL n ${ }^{\circ} 571$, de 28 de setembro de 2011 ......... 371

Resolução da ANATEL n ${ }^{\circ} 572$, de 28 de setembro de 2011 ......... 371

Resolução da ANATEL n ${ }^{\circ} 573$, de 10 de outubro de 2011 .......... 372

Resolução da ANATEL no 574, de 28 de outubro de 2011 .......... 372

Resolução da ANATEL n ${ }^{\circ} 575$, de 28 de outubro de 2011 .......... 372

Resolução da ANATEL no 576 , de 31 de outubro de 2011 .......... 372

Resolução da ANATEL n ${ }^{\circ} 577$, de 24 de novembro de 2011 ........ 373

Resolução da ANATEL n ${ }^{\circ} 578$, de 30 de novembro de 2011 ........ 373

Atos Referenciados ................................................ 373

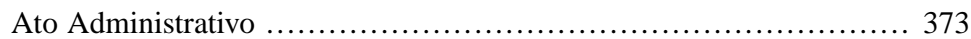

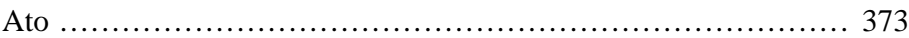

Ato da Superintendência de Radiofrequencia e Fiscalização e da Superintendência de Serviços Públicos da ANATEL n 160 , de 6 de janeiro de 2011 .................................. 373

Ato da Superintendência de Radiofrequencia e Fiscalização e da Superintendência de Serviços Públicos da ANATEL n ${ }^{\circ} 161$, de 6 de janeiro de 2011 ....................................... 374 Ato da Superintendência de Radiofrequencia e Fiscalização e da Superintendência de Serviços Públicos da ANATEL n ${ }^{\circ} 162$, de 6 de janeiro de 2011 
Ato do Conselho Diretor da ANATEL $n^{\circ} 1.970$, de $1^{\circ}$ de abril de 2011

Ato do Conselho Diretor da ANATEL n ${ }^{\circ} 2.282$, de 15 de abril de

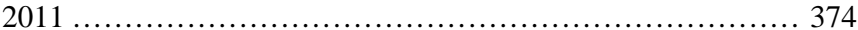
Ato do Conselho Diretor da ANATEL n ${ }^{\circ} 5.156$, de 22 de julho

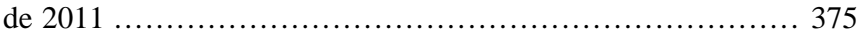

Consulta Pública ......................................... 375

Ato do Conselho Diretor da ANATEL n ${ }^{\circ} 5.703$, de 16 de agosto

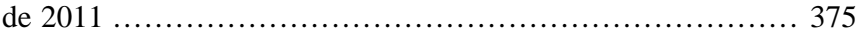

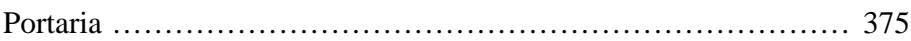

Portaria do Ministério das Comunicações no 69/2011 ......... 375

Portaria ANATEL no 941, de 28 de outubro de $2011 \ldots \ldots \ldots . . . .375$

Relatório Anual da ANATEL ..................................... 376

Relatório Anual da ANATEL 2010 .......................... 376

Súmula ................................................ 376

Súmula da ANATEL no 10, de 15 de março de $2011 \ldots \ldots \ldots . . . .376$

Súmula da ANATEL n ${ }^{\circ} 11$, de 17 de novembro de $2011 \ldots \ldots . . .376$

Súmula da ANATEL n ${ }^{\circ} 12$, de 19 de dezembro de $2011 \ldots \ldots . . .376$

Índice Alfabético e Remissivo ............................................. 379 


\section{Lista de Abreviaturas e Siglas}

$1 \mathrm{G}$

$2.5 \mathrm{G}$

$2 \mathrm{G}$

$3 \mathrm{G}$

3G HS

AACD

ABA

ABAP

ABAR

ABCiber

ABEMTIC

ABEPEC

ABEPEC

ABEPREST

ABERT

ABETS

ABIFUMO

ABINEE

ABJC

ABNT

ABPI-TV

ABPITV

ABPTA

ABR Telecom

ABRA

ABRACOM

ABRADECEL

ABRAFIC

ABRAFIX

ABRAPPIT
Primeira Geração de Tecnologia de Telefonia Móvel (analógico).

Geração 2.5 de Tecnologia de Telefonia Móvel (GPRS).

Segunda Geração de Tecnologia de Telefonia Móvel (digital para dados, 9.6-14.4Kbps).

Terceira Geração de Tecnologia de Telefonia Móvel (digital para voz e dados, mínimo de 144Kbps).

3G High Speed (Rede celular de Terceira geração de Alto Desempenho).

Associação de Assistência à Criança Defeituosa.

Associação Brasileira de Anunciantes.

Associação Brasileira de Agências de Propaganda.

Associação Brasileira de Agências de Regulação.

Associação Brasileira de Pesquisadores em Cibercultura.

Associação Brasileira de Entidades Municipais de Tecnologia da Informação e Comunicação.

Associação Brasileira das Emissoras Públicas Educativas e Culturais.

Associação Brasileira de Ensino e Pesquisa em Comunicação (inativa).

Associação Brasileira de Empresas de Soluções de Telecomunicações e Informática.

Associação Brasileira de Emissoras de Rádio e Televisão.

Associação Brasileira das Empresas de Telecomunicações por Satélite.

Associação Brasileira da Indústria do Fumo.

Associação Brasileira da Indústria Elétrica e Eletrônica.

Associação Brasileira de Jornalismo Científico.

Associação Brasileira de Normas Técnicas.

Associação Brasileira de Produtores Independentes de Televisão.

Associação Brasileira das Empresas Produtoras Independentes de Televisão.

Associação Brasileira dos Programadores de TV por Assinatura.

Associação Brasileira de Recursos de Telecomunicações (Portabilidade Numérica).

Associação Brasileira de Radiodifusores.

Associação Brasileira de Antenas Comunitárias.

Associação Brasileira de Defesa dos Moradores e Usuários Intraquilos com Equipamentos de Telecomunicações Celular.

Associação Brasileira de Film Commissions (Brazilian Association of Film Commissions).

Associação Brasileira de Concessionárias de Serviço Telefônico Fixo Comutado.

Associação Brasileira de Pequenos Provedores de Internet e Telecomunicações. 
ABRATEL

ABRATER

ABRINT

ABRISAN

ABTA

ABTU

Acel

ACERP

AD

ADGI

ADI

ADPF

ADSL

AEB

AET

AGVSEL

$\mathrm{Ah}$

AI

AI

AI/E

AICE

AIE

AIRR

ALAIC

ALCA

ALCAR

AM

AM-DSB-SC

AME

AMMB

AMN

AMNT

AMPS

AN

AN

ANACOM

ANATEL
Associação Brasileira de Radiodifusão, Tecnologia e Telecomunicações.

Associação Brasileira de Telecomunicações Rurais.

Associação Brasileira de Provedores de Internet e Telecomunicações.

Associação Brasileira de Registro de Obras Audiovisuais.

Associação Brasileira de TV por Assinatura.

Associação Brasileira de Televisão Universitária.

Associação Nacional das Operadoras Celulares.

Associação de Comunicação Educativa Roquette Pinto.

Adicional por Chamada (Serviço Móvel Pessoal).

Gerência Geral de Gestão da Informação (ANATEL).

Ação Direta de Inconstitucionalidade (Jurisdição).

Gerência Geral de Planejamento, Orçamento e Finanças (ANATEL).

Asymmetric Digital Subscriber Line.

Agência Espacial Brasileira.

Associação dos Engenheiros de Telecomunicações.

Agravo em Suspensão de Execução de Liminar.

Ampère-hora.

Acesso Instalado.

Agravo de Instrumento (Jurisdição).

Acesso Instalado da Estação de Comutação.

Acesso Individual Classe Especial.

Acesso Instalado Equivalente.

Agravo de Instrumento em Recurso de Revista (Tribunal Superior do Trabalho).

Asociación Latinoamericana de Investigadores de la Comunicación.

Área de Livre Comércio das Américas.

Associação Brasileira dos Pesquisadores de História da Mídia.

Amplitude Modulation (Modulação em Amplitude).

Amplitude Modulation, Double-Sided Band, Suppressed Carrier

(Modulação em Amplitude, em Faixa Lateral Dupla, com Portadora Suprimida).

Valor de Ativo Moderno Equivalente (Separação e Alocação de Contas).

Associação de Marketing Móvel do Brasil.

Artificial Mains Network (Rede Fictícia em V).

Assembléia Mundial de Normalização das Telecomunicações.

Advanced Mobile Phone System (Rede celular 1G).

Área de Numeração.

Área de Numeração (Serviço Telefônico Fixo Comutado).

Autoridade Nacional de Comunicações (de Portugal).

Agência Nacional de Telecomunicações. 
ANCINE

ANEEL

ANER

ANER

ANJ

ANOp

ANP

ANSI

ANTT

APEX-Brasil

APS

Aptel

AR

AR

AR

AR

ARIB

ARM

ART

ASTM

AT

AT

ATA

ATB

ATB

ATC

ATS

ATSC

AVADAN

BACEN

BAL

$\mathrm{BB}$

$\mathrm{BBC}$

$\mathrm{BCB}$

$\mathrm{BDO}$

BDR

BDR

BDT
Agência Nacional do Cinema.

Agência Nacional de Energia Elétrica.

Associação Nacional das Empresas de Revistas.

Associação Nacional dos Servidores Efetivos das Agências Reguladoras.

Associação Nacional de Jornais.

Auditoria de Natureza Operacional (Tribunal de Contas da União).

Agência Nacional do Petróleo.

American National Standards Institute.

Agência Nacional de Transportes Terrestres.

Agência de Promoção de Exportações do Brasil.

Área de Prestação do Serviço (Serviços de Televisão por Assinatura).

Associação de Empresas Proprietárias de Infra-Estrutura e de Sistemas Privados de Telecomunicações.

Área de Registro.

Área de Registro (Serviço Móvel Especializado).

Área de Registro (Serviço Móvel Pessoal).

Área de Registro (Serviço Telefônico Fixo Comutado).

Association of Radio Industries and Businesses (Japão).

Acordo de Reconhecimento Mútuo (Certificação e Homologação).

Anotação de Responsabilidade Técnica.

American Society for Testing and Materials.

Área de Tarifação (Serviço Móvel Especializado).

Área de Tarifação (Serviço Móvel Pessoal).

Analog Telephone Adaptor.

Área de Tarifa Básica.

Área de Tarifação Básica (Serviço Telefônico Fixo Comutado).

Ativos de Tecnologia Corrente (Separação e Alocação de Contas).

Ativos de Tecnologia Substituída (Separação e Alocação de Contas).

Advanced Television Systems Committee (Padrão de TV Digital Estados Unidos da América).

Avaliação de Danos - Formulário (Sistema Nacional de Defesa Civil).

Banco Central do Brasil.

Balanceamento Longitudinal.

Banda-Base.

British Broadcasting Corporation (Reino Unido).

Banco Central do Brasil.

Base de Dados Operacional (Portabilidade).

Base de Dados de Referência (Portabilidade).

Base de Dados Nacional de Referência da Portabilidade.

Bureau de Développement des Télécommunications (Escritório de Desenvolvimento das Telecomunicações da UIT). 
BDTA

BGAN

BIA

BID

BIRD

BIS

Bn

BNDES

BPL

BR

\section{BRASSCOM}

BS

BSR

BT

BWA

C-INI

$\mathrm{C} 0,25$

C10

C120

CA

CAACI

CADE

CADIN

CAMR

CAPDA

CAPT

CARR

CATIS

$\mathrm{CBC}$

$\mathrm{CBC} 1$

CBC 2

CBC 3
Banco de Dados Técnicos e Administrativos (Radiofreqüência).

Broadband Global Area Network (INMARSAT).

Bens e Instalações em Andamento (Separação e Alocação de Contas).

Banco Interamericano de Desenvolvimento.

Banco Internacional para Reconstrução e Desenvolvimento (Banco Mundial).

Bens e Instalações em Serviço (Separação e Alocação de Contas).

Largura da Faixa Necessária (Certificação).

Banco Nacional de Desenvolvimento Econômico e Social.

Broadband over Power Lines (Banda larga por meio de redes de energia elétrica).

Bureau des Radiocommunications (Escritório de Radiocomunicações da UIT).

Associação Brasileira de Empresas de Tecnologia da Informação e Comunicação.

Base Station (Estação Rádio Base).

Bloqueador de Sinais de Radiocomunicações.

Linha de distribuição de Baixa Tensão.

Broadband Wireless Access (4G).

Comitê sobre Infra-estrutura Nacional de Informações.

Capacidade nominal para regime de alta intensidade de descarga $(\mathrm{C} 0,25)$.

Capacidade nominal para regime de média intensidade de descarga (C10).

Capacidade nominal para regime de baixa intensidade de descarga (C120).

Corrente Alternada.

Conferência de Autoridades Audiovisuais e Cinematográficas IberoAmericana.

Conselho Administrativo de Defesa Econômica.

Cadastro Informativo de Créditos não Quitados do Setor Público Federal.

Conferência Administrativa Mundial de Radiocomunicações.

Comitê das Atividades de Pesquisa e Desenvolvimento na Amazônia.

Controle Automático da Potência Transmitida.

Conferência Administrativa Regional de Radiocomunicações.

Centro de Acesso a Tecnologias para a Inclusão Social.

Comissão Brasileira de Comunicações.

Comissão Brasileira de Comunicações ${ }^{\circ} 1$ - Redes de Dados e Características de Sistemas Telemáticos (extinta).

Comissão Brasileira de Comunicações n ${ }^{\circ} 2$ - Transmissão de Áudio e Vídeo e Sistemas Multimídia (extinta).

Comissão Brasileira de Comunicações $n^{\circ} 3$ - Tarifas e Princípios Contábeis (extinta). 
CBC 4

CBC 5

CBC 6

CBC 7

CBC 8

CBC 9

CBC 1

CBC 10

CBC 11

CBC 12

CBC 13

CBC 2

CBC 3

CBC 4

CBC Temp.

CBDT

CBLC

CBR

CBT

CBTTs

$\mathrm{CC}$

CCC

$\mathrm{CCC}$

$\mathrm{CCC}$

CCIR

CCITT

CCJC

$\mathrm{CCOM}$

CCP.I
Comissão Brasileira de Comunicações no 4 - Definição de Serviços, Planos Estruturais e Gerência de Redes (extinta).

Comissão Brasileira de Comunicações n ${ }^{\circ} 5$ - Sinalização, Comutação, Protocolos, Linguagens e Aspectos Gerais de Redes (extinta).

Comissão Brasileira de Comunicações $n^{\circ} 6$ - Planta Externa e Compatibilidade Eletromagnética (extinta).

Comissão Brasileira de Comunicações $n^{\circ} 7$ - Desenvolvimento das Telecomunicações (extinta).

Comissão Brasileira de Comunicações $n^{\circ} 8$ - Serviços Móveis, de Radiodeterminação e de Radioamador (extinta).

Comissão Brasileira de Comunicações $n^{\circ} 9$ - Serviços Fixos e Científicos (extinta).

Comissão Brasileira de Comunicações $n^{\circ} 1$ - Governança e Regimes Internacionais.

Comissão Brasileira de Comunicações $n^{\circ} 10$ - Administração do Espectro Radioelétrico e Propagação (extinta).

Comissão Brasileira de Comunicações $n^{\circ} 11$ - Radiodifusão (extinta).

Comissão Brasileira de Comunicações $\mathrm{n}^{\circ} 12$ - Negociações Internacionais em Telecomunicações (extinta).

Comissão Brasileira de Comunicações n ${ }^{\circ} 13$ - Governança da Internet (extinta).

Comissão Brasileira de Comunicações n ${ }^{\circ} 2$ - Radiocomunicações.

Comissão Brasileira de Comunicações $\mathrm{n}^{\circ} 3$ - Normalização de Telecomunicações.

Comissão Brasileira de Comunicações n ${ }^{\circ} 4$ - Desenvolvimento das Telecomunicações.

Comissão Brasileira de Telecomunicações Temporária.

Coleção Brasileira de Direito Regulatório das Telecomunicações.

Comissão Brasileira de Liquidação e Custódia.

Comissão Brasileira de Radiocomunicações.

Código Brasileiro de Telecomunicações (Lei n 4.117/62).

Comissões Brasileiras de Telecomunicações.

Corrente Contínua.

Central de Comutação e Controle (Serviço Móvel Pessoal).

Central de Comutação e Controle (Sistemas de Acesso sem Fio do STFC).

Central de Controle e Comutação do SMC (Internacional).

Comitê Consultivo Internacional das Radiocomunicações.

Comitê Consultivo Internacional de Telegrafia e Telefonia.

Comissão de Constituição e Justiça e de Cidadania.

Centro de Políticas, Direito, Economia e Tecnologias das Comunicações da UnB.

Comitê Consultivo Permanente $\mathrm{n}^{\circ} 1$ da Comissão Interamericana de Telecomunicações. 
CCP.II

CCP.III

CCPs-CITEL

CCT

CCT

CCT

CCTCI

ccTLD

CDA

CDC

CDEIC

CDI

CDMA

CDMA 1XEV-DO

CDMA 1xEV-DV

CDUST

CEDEC

CEFET

CEITEC

CENAD

CENELEC

CEPED

CERT.br

CETIC.br

CFM

CFTV

CG-CBC

CG-ProTIC

CGCOB

CGIbr
Comitê Consultivo Permanente $\mathrm{n}^{\circ} 2$ da Comissão Interamericana de Telecomunicações.

Comitê Consultivo Permanente $n^{\circ} 3$ da Comissão Interamericana de Telecomunicações.

Comitês Consultivos Permanentes da CITEL.

Cargo Comissionado Técnico (Agências Reguladoras).

Comissão de Ciência, Tecnologia, Inovação, Comunicação e Informática (Senado Federal).

Conselho Nacional de Ciência e Tecnologia.

Comissão de Ciência e Tecnologia, Comunicação e Informática (Câmara dos Deputados).

country code Top Level Domain (Domínio de Primeiro Nível) (INTERNET).

Certidão de Dívida Ativa.

Código de Defesa do Consumidor.

Comissão de Desenvolvimento Econômico, Indústria e Comércio (Câmara dos Deputados).

Comutação Digital Integrada.

Code Division Multiple Access (Múltiplo Acesso por Divisão em Código).

CDMA Evolution Data-Optimized (Rede celular 3G).

CDMA Evolution, Data and Voice (Rede celular 3G).

Comitê de Defesa dos Usuários de Serviços de Telecomunicações.

Coordenadoria Estadual de Defesa Civil (Sistema Nacional de Defesa Civil).

Centro Federal de Educação Tecnológica.

Centro Nacional de Tecnologia Eletrônica Avançada S.A.

Centro Nacional de Gerenciamento de Riscos e Desastres (Sistema Nacional de Defesa Civil).

European Commitee for Electrotechnical Standardization.

Centro Universitário de Ensino e Pesquisa sobre Desastres (Sistema Nacional de Defesa Civil).

Centro de Estudos, Resposta e Tratamento de Incidentes de Segurança no Brasil (Comitê Gestor da Internet no Brasil).

Centro de Estudos sobre as Tecnologias da Informação e da Comunicação (Comitê Gestor da Internet no Brasil).

Conselho Federal de Medicina.

Serviço Especial de Circuito Fechado de Televisão com Utilização de Radioenlace.

Grupo de Coordenação das Comissões Brasileiras de Comunicações. Comitê Gestor do Programa de Apoio à Pesquisa, Desenvolvimento e Inovação em Tecnologias Digitais de Informação e Comunicação.

Coordenação-Geral de Cobrança e Recuperação de Créditos.

Comitê Gestor da Internet no Brasil. 
CGPD

CGPID

CGRBT

CIC

CIDE

CIP

CIPA

CISCOMIS

CITEL

CMDT

CMGLO

CMI

CMPC

CMR

CMSI

$\mathrm{CN}$

CNAL

$\mathrm{CNC}$

CNDI

CNI

$\mathrm{CNPq}$

CNPq-MCT

$\mathrm{COE}$

COE

COER

COFDM

COFINS

COG

COGEF

COMDEC

COMPÓS

CONANDA

Conapsi

CONAR

CONARQ
Comitê Gestor de Políticas de Inclusão das Pessoas com Deficiência (Presidência da República).

CGPID.

Comitê Gestor de Articulação Institucional da Rede Brasil de Tecnologia.

Central de Intermediação de Comunicação Telefônica.

Contribuição de Intervenção no Domínio Econômico.

Câmara Interbancária de Pagamentos.

Comissão Interna de Prevenção de Acidentes.

Comissão de Desenvolvimento do Projeto e da Implantação do Sistema de Comunicações Militares por Satélite.

Comissão Interamericana de Telecomunicações.

Conferência Mundial de Desenvolvimento das Telecomunicações.

Gerência de Engenharia, Planejamento e Controle de Licitações e Outorgas.

Cúpula Mundial da Informação.

Custo Médio Ponderado de Capital.

Conferência Mundial de Radiocomunicações.

Cúpula Mundial sobre a Sociedade da Informação (World Summit on the Information Society - WSIS).

Código Nacional.

Cadastro Nacional de Áreas Locais.

Conselho Nacional de Comunicações.

Conselho Nacional de Desenvolvimento Industrial.

Confederação Nacional da Indústria.

Conselho Nacional de Desenvolvimento Científico e Tecnológico.

Centro Nacional de Pesquisa do Ministério da Ciência e Tecnologia.

Coeficiente de Onda Estacionária.

Coeficiente de Reflexão.

Certificado de Operador de Estação de Radioamador.

Coded Orthogonal Frequency Division Multiplexing.

Contribuição para o Financiamento da Seguridade Social.

Cabo Óptico Geral.

Comissão de Gerência do Espectro de Radiofreqüência de Interesse do Ministério da Defesa.

Coordenadoria Municipal de Defesa Civil (Sistema Nacional de Defesa Civil).

Associação Nacional das Pós-Graduações em Comunicação.

Conselho Nacional dos Direitos da Criança e do Adolescente.

Conselho Nacional dos Provedores de Serviço de Internet.

Conselho Nacional de Auto-Regulamentação Publicitária.

Conselho Nacional de Arquivos. 


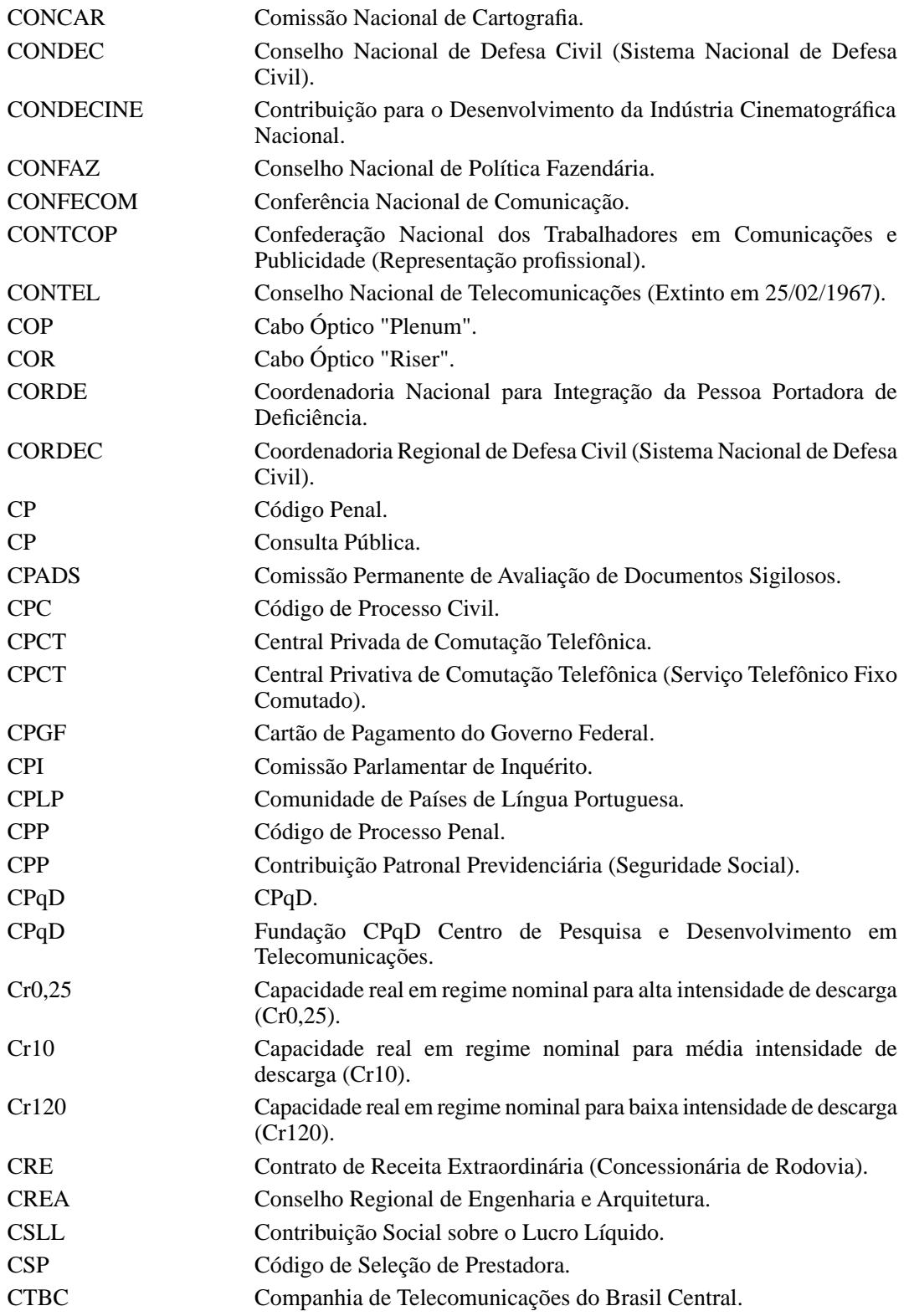


CTs-SGT.1-MERCOSUL Comissões Temáticas do Subgrupo de Trabalho de Comunicações do MERCOSUL.

CVM Comissão de Valores Mobiliários.

CVR

Relações Custo-Volume (Separação e Alocação de Contas).

D-AMPS

DAC

Digital Advanced Mobile Phone System.

DAS

Departamento de Aviação Civil.

$\mathrm{dB}$

Direção e Assessoramento Superiores.

dB SPL

Decibel.

dB SPL(A)

dB V

dBA

DBDG

$\mathrm{dBk}$

dBmp

$\mathrm{dBPa}$

$\mathrm{dBPa}(\mathrm{A})$

$\mathrm{dB} \mu$

$\mathrm{dB} \mu$

DCOR

DCS

DDG

DDI

DDR

DEA

DECEA

DECT

DEINT

DENTEL

DEPEN

DEPV

DETRAF

DG

DIC

DISTV

DJ

DJe

DLC
Decibel relativo a $20 \mu \mathrm{Pa}$.

Decibel relativo a $20 \mu \mathrm{Pa}$ medido com ponderação A (IEC 60651).

Decibel Relativo a $1 \mathrm{~V}$.

dBA.

Diretório Brasileiro de Dados Geoespaciais (DBDG).

Potência, em dB, relativa a $1 \mathrm{~kW}$.

Decibel medido com ponderação psofométrica (Rec. O.41 da ITU-T).

Decibel Relativo a 1 Pascal.

Decibel relativo a $1 \mathrm{~Pa}$ medido com ponderação A (IEC 60651).

Decibel Relativo a $1 \mathrm{~mW}$.

Intensidade de campo, em dB, relativa a $1 \mu \mathrm{V} / \mathrm{m}$.

Diretoria de Concessões e Operações Rodoviárias.

Digital Cellular Network.

Discagem Direta Gratuita.

Discagem Direta Internacional.

Discagem Direta a Ramal.

Data Envelopment Analysis.

Departamento de Controle do Espaço Aéreo.

DECT.

Departamento de Negociações Internacionais da Secretaria de Comércio Exterior do Ministério da Indústria, do Comércio e do Turismo.

Departamento Nacional de Telecomunicações (Extinto em 15/03/1990).

Departamento Penitenciário Nacional.

Diretoria de Eletrônica e Proteção ao Vôo (Min. Aeronáutica), extinta em 5.10.2001.

Documento de Declaração de Tráfego e de Prestação de Serviços.

Distribuidor Geral (Serviço Telefônico Fixo Comutado).

Discagem Interurbana a Cobrar.

Serviço de Distribuição de Sinais de TV por Meios Físicos.

Diário da Justiça (Imprensa Nacional).

Diário da Justiça eletrônico.

Discagem Local a Cobrar. 


\begin{tabular}{|c|c|}
\hline DNER & Departamento Nacional de Estradas de Rodagem. \\
\hline DNS & Domain Name System. \\
\hline DOP & Documento Operacional de Prazos da Portabilidade. \\
\hline DPDC & Departamento de Proteção e Defesa do Consumidor. \\
\hline DRM & Digital Radio Mondiale (padrão europeu de rádio digital). \\
\hline DS-CDMA & Múltiplo Acesso por Divisão em Código com Seqüência Direta. \\
\hline DSAC & Documento de Separação e Alocação de Contas. \\
\hline DSB & Double Side Band 'Modulation' (Modulação em Faixa Lateral Dupla). \\
\hline DSC & Documento Sigiloso Controlado. \\
\hline DSL & Digital Subscriber Line. \\
\hline DTH & $\begin{array}{l}\text { Direct-to-Home (Serviço de Distribuição de Sinais de Televisão e de } \\
\text { Áudio por Assinatura Via Satélite). }\end{array}$ \\
\hline DTH & $\begin{array}{l}\text { Serviço de Distribuição de Sinais de Televisão e de Áudio por } \\
\text { Assinatura Via Satélite. }\end{array}$ \\
\hline DTMF & Dual Tone Multi-Frequency. \\
\hline DVB & Digital Video Broadcasting (Padrão de TV Digital - União Européia). \\
\hline DVB-H & Digital Video Broadcasting Handheld. \\
\hline e-DJF1 & $\begin{array}{l}\text { Diário da Justiça Federal da Primeira Região eletrônico (TRF } 1^{\mathrm{a}} \\
\text { Região). }\end{array}$ \\
\hline e.i.r.p. & Potência Equivalente Isotropicamente Radiada. \\
\hline e.r.p. & Potência Efetiva Radiada (Campo Eletromagnético). \\
\hline e.r.p. & Potência Efetivamente Irradiada. \\
\hline EB & Estação Base. \\
\hline EBC & Empresa Brasil de Comunicação. \\
\hline EBITDA & Earning Before Interest, Tax, Depreciation and Amortization. \\
\hline $\mathrm{EC}$ & Estação de Controle. \\
\hline $\mathrm{Ec} / \mathrm{ec}$ & Campo Característico, respectivamente em $\mathrm{dB} \mu \mathrm{e} \mathrm{mV} / \mathrm{m}$. \\
\hline ECA & Estatuto da Criança e do Adolescente. \\
\hline ECAD & Escritório Central de Arrecadação e Distribuição. \\
\hline ECD & Equipamento de Comunicação de Dados. \\
\hline ECT & Empresa Brasileira de Correios e Telégrafos. \\
\hline EDGE & EDGE. \\
\hline EEII & Empresa Exploradora de Troncos Interestaduais e Internacionais. \\
\hline EESPT & $\begin{array}{l}\text { Entidade Exploradora de Serviços Públicos de Telecomunicações (em } \\
\text { desuso). }\end{array}$ \\
\hline EHF & Extremely High Frequency. \\
\hline EILD & Exploração Industrial de Linha Dedicada. \\
\hline ELI & Estágio de Linha Integrado. \\
\hline ELR & Estágio de Linha Remoto. \\
\hline EM & Estação Móvel. \\
\hline Enom / enom & $\begin{array}{l}\text { Intensidade de campo nominal utilizável, respectivamente em } \mathrm{dB} \mu \text { e } \\
\mathrm{mV} / \mathrm{m} \text {. }\end{array}$ \\
\hline
\end{tabular}


ENUM

EPMU

EPON

ER

ER

ERB

ERB

ERC

ERG

ERP

ERUE

ESC

ET

ETA

ETD

ETSI

$\mathrm{Eu} / \mathrm{eu}$

EUE

FA

FAC

FCC

FCPT

FCT

FCT

FDD

FDMA

FEBRAPEL

FENAJ

FGP

FGTS

FH-CDMA

FINEP

FISTEL

FITTEL

FM

FMCA

FNC

FNDCT
Telephony Numbering Mapping (Protocolo desenvolvido pela IETF).

Equal Proporcionate Mark Up (Alocação Proporcional e Eqüitativa - Separação e Alocação de Contas).

Ethernet Passive Optical Network.

Estação Repetidora.

Estágio Remoto (Serviço Telefônico Fixo Comutado).

Estação Rádio Base.

Estação Rádio Base (Serviço Móvel Pessoal).

Estação Radioelétrica Central.

European Regulators Group.

Potência Efetivamente Radiada.

Eficiência Relativa de Uso do Espectro (ERUE).

Equipamento a Ser Certificado.

Estação Terminal.

Estação Terminal de Acesso.

Equipamento Terminal de Dados.

European Telecommunications Standards Institute.

Intensidade de campo utilizável, respectivamente em $\mathrm{dB} \mu$ e $\mathrm{mV} / \mathrm{m}$.

Eficiência de Uso do Espectro (EUE).

Fator de Amortecimento.

Fully Allocated Costs (Custos Totalmente Alocados).

Federal Communications Commission (United States of America).

Fórum de Certificação de Produtos para Telecomunicações.

Função Comissionada Técnica.

Funções Comissionadas de Telecomunicações.

Frequency Division Duplexing (Duplexação por Divisão na Frequência).

Frequency Division Multiple Access (Múltiplo Acesso por Divisão em Frequência).

Federação Brasileira de Telecomunicações (Representação empresarial).

Federação Nacional dos Jornalistas.

Fundo Garantidor de Parcerias Público-Privadas.

Fundo de Garantia por Tempo de Serviço.

Múltiplo Acesso por Divisão em Código com Saltos de Freqüência.

Financiadora de Estudos e Projetos.

Fundo de Fiscalização das Telecomunicações.

Federação Interestadual dos Trabalhadores em Telecomunicações.

Frequência Modulada.

Fixed-Mobile Convergence Alliance.

Fundo Nacional da Cultura.

Fundo Nacional de Desenvolvimento Científico e Tecnológico. 
FNPJ

FNT

Fonacate

FORCINE

FS

FTTB

FTTC

FTTH

FTTN

FUNCAP

Fundomic

Funtec

FUNTTEL

FUST

FWA

GCOM

GESAC

GETEL

GGSN

GIP

GIP

GIPAQ

GMC

GMDSS

GNR

GPON

GPRS

GPS

GSM

GTI

HCA

HCA

HCI

$\mathrm{HF}$

HFBC
Fórum Nacional de Professores de Jornalismo.

Fundo Nacional de Telecomunicações.

Fórum Nacional Permanente de Carreiras Típicas de Estado.

Fórum Brasileiro de Ensino de Cinema e Audiovisual.

Fornecedora de Sinal.

Fiber to the Building.

Fiber to the Curb.

Fiber to the Home.

Fiber to the Node.

Fundo Especial para Calamidades Públicas (Sistema Nacional de Defesa Civil).

Fundo de Universalização do Acesso a Serviços de Telecomunicação (Minas Gerais).

Fundo Tecnológico (BNDES).

Fundo para o Desenvolvimento Tecnológico das Telecomunicações.

Fundo de Universalização dos Serviços de Telecomunicações.

Fixed Wireless Access.

Grupo Interdisciplinar de Políticas, Direito, Economia e Tecnologias das Comunicações (UnB).

Governo Eletrônico - Serviço de Atendimento ao Cidadão.

Grupo de Estudos em Direito das Telecomunicações (UnB).

Gateway GPRS Support Node.

Grupo de Implantação da Portabilidade.

Grupo de Implementação da Portabilidade.

Grupo de Implantação de Processos de Aferição da Qualidade.

Grupo Mercado Comum.

Sistema Global Marítimo de Socorro e Segurança.

Guia Nacional de Recolhimento de Tributos Estaduais.

Gigabit Passive Optical Network.

General Packet Radio Service (Rede celular 2.5G).

Global Positioning System (Sistema de Posicionamento Global).

Global System Mobile -Global System for Mobile Communications (Originariamente Groupe Spécial Mobile).

Grupo de Trabalho Interministerial.

Base de Custos Históricos ( Separação e Alocação de Contas).

Historical Cost Accounting (Base de Custos Históricos na Separação e Alocação de Contas).

Altura do Centro de Fase do Sistema Irradiante.

High Frequency (Alta Freqüência).

Conferência Administrativa Mundial de Radiocomunicações para o planejamento das faixas de ondas decamétricas atribuídas ao serviço de radiodifusão, realizada em 1987. 
HMM

HNMT

HNMT

HSDPA

HSPA

HSUPA

IAF

IAMCR

IAP

IARP

IARU

IBGE

IBICT

IBOC

ICANN

ICAO

ICC

ICCo

ICMS

ICNIRP

ICP-Brasil

ICR

ICT

ICT4D

IDDF

IDEC

IDH

IEC

IEEE

IETF

IFCA

Ifd

IFRB
Hora de Maior Movimento.

Altura da Antena sobre o Nível Médio do Terreno.

Altura do Sistema Irradiante em Relação ao Nível Médio do Terreno (Radiodifusão).

High Speed Downlink Packet Access (Rede celular 3G).

High-Speed Packet Access (tipo de padrão de telefonia móvel por dados) (Rede celular 3G).

High Speed Uplink Packet Access (Rede celular 3G).

International Accreditation Forum (Certificação e Homologação).

International Association for Media and Communication Research.

Índice de Atendimento Pessoal.

International Amateur Radio Permission (Permissão Internacional de Radioamador).

União Internacional de Radioamadores.

Instituto Brasileiro de Geografia e Estatística.

Instituto Brasileiro de Informação em Ciência e Tecnologia.

In-Band On-Channel (padrão norte-americano de rádio digital).

Internet Corporation for Assigned Names and Numbers (Corporação da Imternet para a Atribuição de Nomes e Números).

Organização Internacional de Aviação Civil.

Índice de Chamadas Completadas.

Índice de Cessação de Cobrança.

Imposto sobre Operações Relativas à Circulação de Mercadorias e Sobre Prestações de Serviços de Transporte Interestadual, Intermunicipal e de Comunicações.

International Commission on Non Ionizing Radiation Protection (Comissão Internacional de Proteção Contra Radiações Não Ionizantes).

Infraestrutura de Chaves Públicas Brasileira.

Índice de Correspondências Respondidas.

Instituição Científica e Tecnológica.

Information and Communication Technologies for Development.

Informações de Demanda e Dados Físicos (Separação e Alocação de Contas).

Instituto de Defesa do Consumidor.

Índice de Desenvolvimento Humano.

International Electrotechnical Commission.

Institute of Electrical and Electronics Engineers.

Internet Engineering Task Force (Força Tarefa de Engenharia da Internet).

International Federation of Mass Communication Associations.

Fator de Degradação.

Junta Internacional de Registro de Frequências. 
IFS

IGF

IGP-DI

IGP-M

II

IIS

IITS

ILA

ILAC

IME

IMO

IMSI

IMT-2000

INDE

INFRAERO

INI

INMARSAT

INMETRO

INTELSAT

Intercom

IP

IP

IPAOG/FGV

IPCA/IBGE

IPI

IPTF

IPTF DEA

IPTF F

IPTF F

IPTV

IQF

IQP

IQP

IR

IREDC
Serviço Franqueado Internacional.

Internet Governance Fórum (Fórum de Governança da Internet vinculado à $\mathrm{ONU}$ ).

Índice Geral de Preços - Disponibilidade Interna.

Índice Geral de Preços - Mercado.

Imposto de Importação.

Índice de Instalação do Serviço.

Índice de Interrupções Solucionadas.

Índice de Ligações Atendidas.

International Laboratories Accreditation Cooperation (Certificação e Homologação).

Índice Mínimo de EUE (IME).

Organização Marítima Internacional.

International Mobile Subscriber Identity (Identificação Internacional de Acesso Móvel).

International Mobile Telecommunications-2000.

Infraestrutura Nacional de Dados Espaciais (INDE).

Empresa Brasileira de Infra-estrutura Aeroportuária.

Infraestrutura Nacional de Informações.

Organização Internacional de Telecomunicações Marítimas por Satélite.

Instituto Nacional de Metrologia, Normalização e Qualidade Industrial.

International Telecommunications Satellite Consortium (Organização Internacional de Telecomunicações por Satélite).

Sociedade Brasileira de Estudos Interdisciplinares da Comunicação. Índice de Preços.

Internet Protocol (Protocolo de Internet).

Índice de Preços por Atacado - Oferta Global.

Índice de Preços ao Consumidor Amplo.

Imposto sobre Produtos Industrializados.

IPTF F.

Índice de Produtividade Total de Fatores DEA.

Índice de Produtividade Total de Fatores Fisher.

Índice de Produtividade Total de Fatores Fisher (Reajuste Tarifário do STFC).

Internet Protocol TV.

Índice de Quantidade dos Fatores de Produção (Reajuste Tarifário do STFC).

Índice de Fator de Produção.

Índice de Quantidade dos Produtos (Reajuste Tarifário do STFC).

Imposto de Renda.

Índice de Reclamação por Erro em Documento de Cobrança. 
IRPJ

IRS

ISAN

ISDB

ISDB-C

ISDB-S

ISDB-T

ISDTV

ISM

ISO

ISP

ISRA

ISS

IST

ISYDS

ITE

ITI

ITU

1

LAN

LaPCom

LBS

LDI

LDN

LED

LEP

LF

LGT

LIBRAS

LLU

LMDS

LPFM

LRGP

LRIC

LSI

LSZH

LTE

LTOG

LUSOCOM
Imposto sobre a Renda da Pessoa Jurídica.

Índice de Reclamação do Serviço.

International Standard Audiovisual Number.

Integrated Services Digital Broadcasting.

Integrated Services Digital Broadcasting Cable.

Integrated Services Digital Broadcasting Satellite Television.

Integrated Services Digital Broadcasting Terrestrial (Serviços Integrados de Radiodifusão Digital Terrestre).

International System for Digital TV (novo nome do SBTVD).

Aplicações Industriais, Científicas e Médicas.

International Standards Organisation.

Internet Service Provider (vide PSCI).

Índice de Solicitações de Reparos Atendidas.

Imposto sobre Serviços de Qualquer Natureza.

Índice de Serviços de Telecomunicações.

Integrated System for Decision Support (vide SIAD).

Índice Temporal de EUE.

Instituto Nacional de Tecnologia da Informação (Autarquia vinculada à Casa Civil da Presidência da República).

International Telecommunication Union (União Internacional de Telecomunicações).

Comprimento de Onda.

Local Area Network.

Laboratório de Políticas de Comunicação da UnB.

Location Based Services.

Longa Distância Internacional.

Longa Distância Nacional.

Light Emitting Diode (Diodo Emissor de Luz).

Lei de Execuções Penais.

Low Frequency.

Lei Geral de Telecomunicações.

Língua Brasileira de Sinais.

Local Loop Unbundling.

Local Point-Multipoint Distribution Service.

Low-Power FM stations (Rádios Comunitárias).

Loudness Rating Guard-Ring Position.

Long Run Incremental Costs (Custos Incrementais de Longo Prazo).

Laboratório de Sistemas Integráveis da USP.

"Low Smoke and Zero Halogen".

Long Term Evolution (Rede Celular 3G).

Lista Telefônica Obrigatória e Gratuita.

Federação Lusófona de Ciências da Comunicação. 
M2M

MAN

MdE

MDGs

MEF

MERCOSUL

MF

MICS

MIFR

MIN

MINFRA

MMDS

MMDS

MMS

MNO

MOB

MOB-87

MOS

MSCID

MT

MVNO

NBM

$\mathrm{NC}$

NCL

$\mathrm{NCM}$

NFC

NFST

NGN

NGT

NOPRED

NPOESS

NRA

NSR

NUDEC

NWA

OCC
Machine to Machine (comunicação entre máquinas).

Metropolitan Area Network.

Memorando de Entendimento - MdE.

Millenium Development Goals (UN Millenium Summit 2000).

Mobile Entertainment Forum.

Mercado Comum do Sul.

Medium Frequency (Média Freqüência).

Sistemas de Comunicações de Implantes Médicos.

Master International Frequency Register (Registro Mestre da UIT).

Valor do Minuto de Tarifação (Serviço Telefônico Fixo Comutado).

Ministério da Infraestrutura (Extinto pela Lei 8.422, de 13/05/1992).

Multichannel Multipoint Distribution Service (Serviço de Distribuição de Sinais Multiponto Multicanal).

Serviço de Distribuição de Sinais Multiponto Multicanal.

Multimedia Message.

Mobile Network Operator (Operador de Rede Móvel).

Conferência Administrativa Mundial de Radiocomunicações para os serviços móveis.

Conferência Administrativa Mundial de Radiocomunicações para os Serviços Móveis, realizada em 1987.

Mean Opinion Score (Pontuação Média de Opinião).

Mobile Switching Center Identification.

Linha de distribuição de Média Tensão.

Mobile Virtual Network Operator (Operador de Rede Virtual Móvel).

Nomenclatura Brasileira de Mercadorias.

Noise Criteria.

Nested Context Language (Interatividade do ISDB-T: linguagem do ambiente Ginga-NCL).

Nomenclatura Comum do Mercosul.

Near Field Communications.

Nota Fiscal de Serviço de Telecomunicações.

Next Generation Network.

Norma Geral de Telecomunicações (Ministério das Comunicações).

Notificação Preliminar de Desastres - Formulário (Sistema Nacional de Defesa Civil).

National Polar-Orbiting Environmental Satellite System.

National Regulatory Authorities (União Européia).

Nível do Sinal Recebido.

Núcleo Comunitário de Defesa Civil (Sistema Nacional de Defesa Civil).

Nomadic Wireless Access (Aplicação Nomádica).

Organismo de Certificação Credenciado. 
OCD

OCDE

OECD

OFDM

OFDMA

OIT

OL

OM

OMC

OPGW

ORB-85

OSCIP

OT

OTI

P\&D

PAC

PAC

PADIS

PADO

PAR

PASEP

PASI

PASOO

PAT

PATVD

PATVD

PBFM

PBOC

PBOM

PBOT
Organismo de Certificação Designado.

Organização para Cooperação e Desenvolvimento Econômico.

Organisation for Economic Co-operation and Development (Organização para Cooperação e Desenvolvimento Econômico).

Orthogonal Frequency Division Multiplexing (Multiplexação Ortogonal por Divisão de Freqüência).

Orthogonal Frequency-Division Multiple Access.

Oxidative Induction Time (Tempo de Indução Oxidativa).

Oscilador Local.

Onda Média.

Organização Mundial do Comércio.

Optical Ground Wire (Cabos Pára-raios com Fibras Ópticas).

Conferência Administrativa Mundial de Radiocomunicações para uso da Órbita de Satélites Geoestacionários e o Planejamento dos Serviços Espaciais que a Utilizam, realizada em 1985.

Organização da Sociedade Civil de Interesse Público.

Onda Tropical.

Organización de Televisión Iberoamericana.

Pesquisa e Desenvolvimento.

Plano Anual de Capacitação (Capacitação Profissional nas Agências Reguladoras).

Programa de Aceleração do Crescimento (Programa de Governo de Janeiro de 2007).

Programa de Apoio ao Desenvolvimento Tecnológico da Indústria de Semicondutores.

Procedimento Administrativo para Apuração de Descumprimento de Obrigações (Agência Nacional de Telecomunicações).

Plano de Aplicação de Recursos (FUNTTEL).

Programa de Formação do Patrimônio do Servidor Público.

Provedor de Acesso a Serviços de Internet.

Plano Alternativo de Serviço de Oferta Obrigatória.

Parcela Adicional de Transição.

Programa de Apoio ao Desenvolvimento Tecnológico da Indústria de Equipamentos para a TV Digital.

Programa de Incentivos ao Setor da TV Digital (Integrante do PAC).

Plano Básico de Distribuição de Canais de Radiodifusão Sonora em Freqüência Modulada.

Plano Básico de Distribuição de Canais de Radiodifusão Sonora em Ondas Curtas.

Plano Básico de Distribuição de Canais de Radiodifusão Sonora em Onda Média.

Plano Básico de Distribuição de Canais de Radiodifusão Sonora em Onda Tropical. 


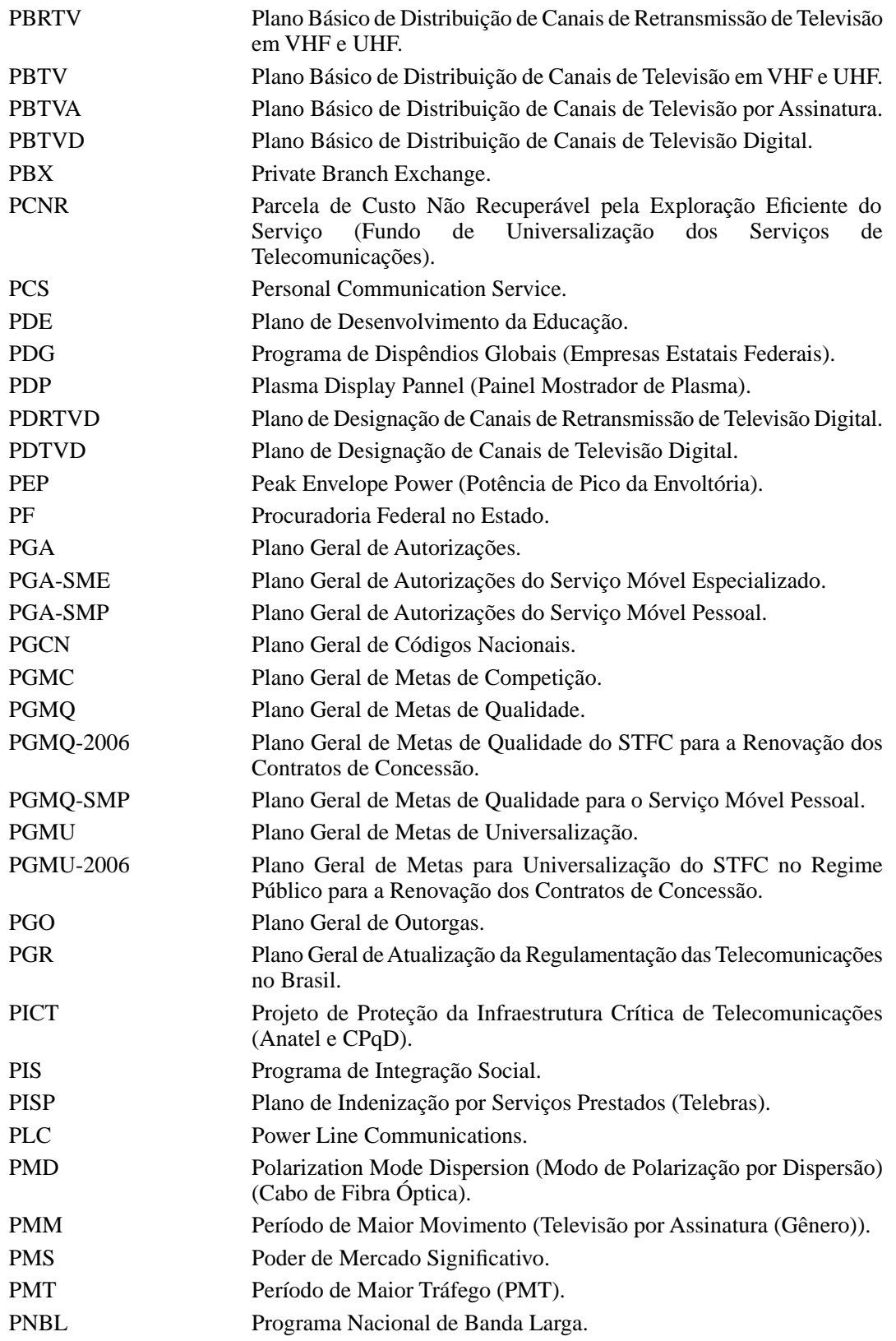




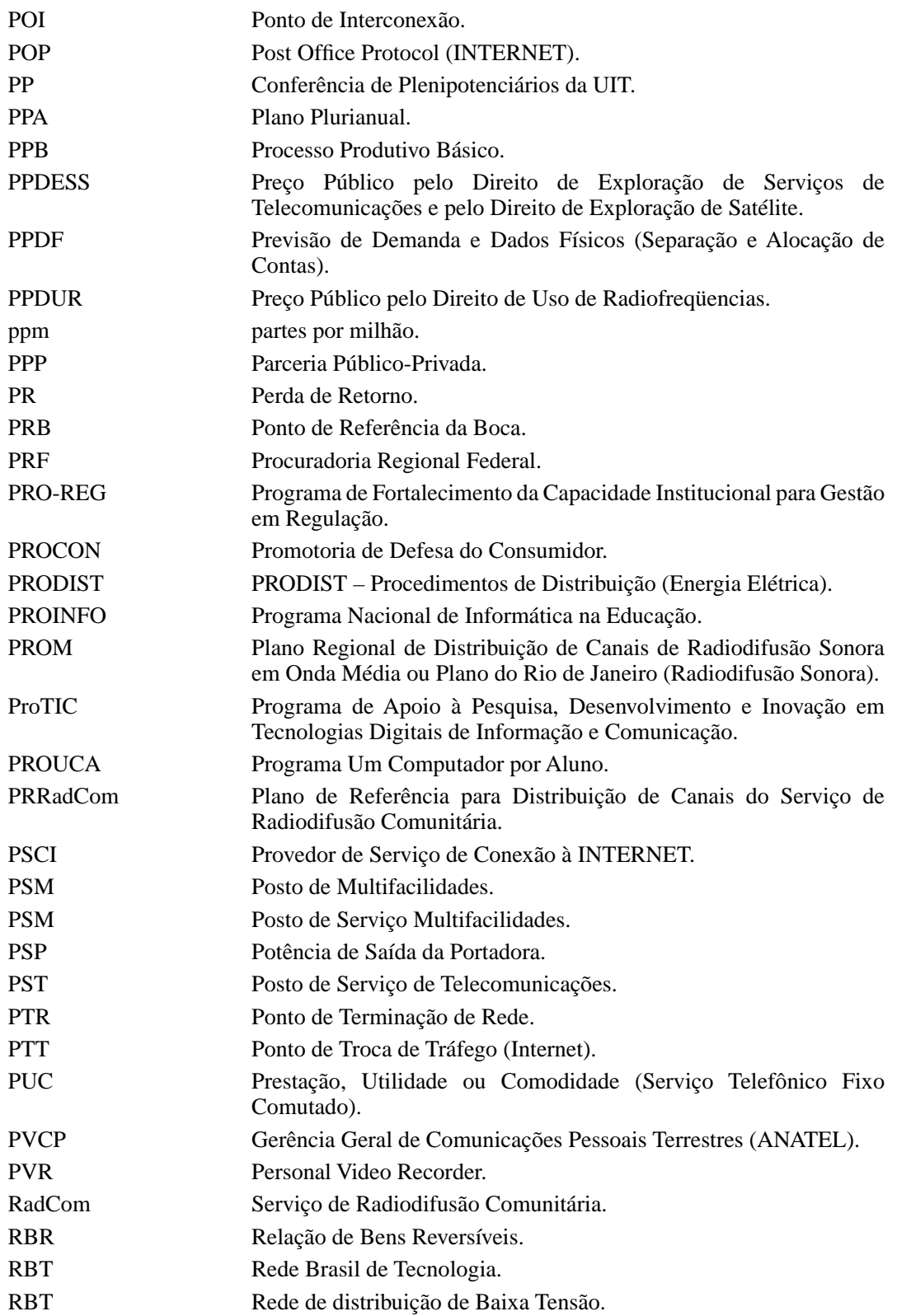




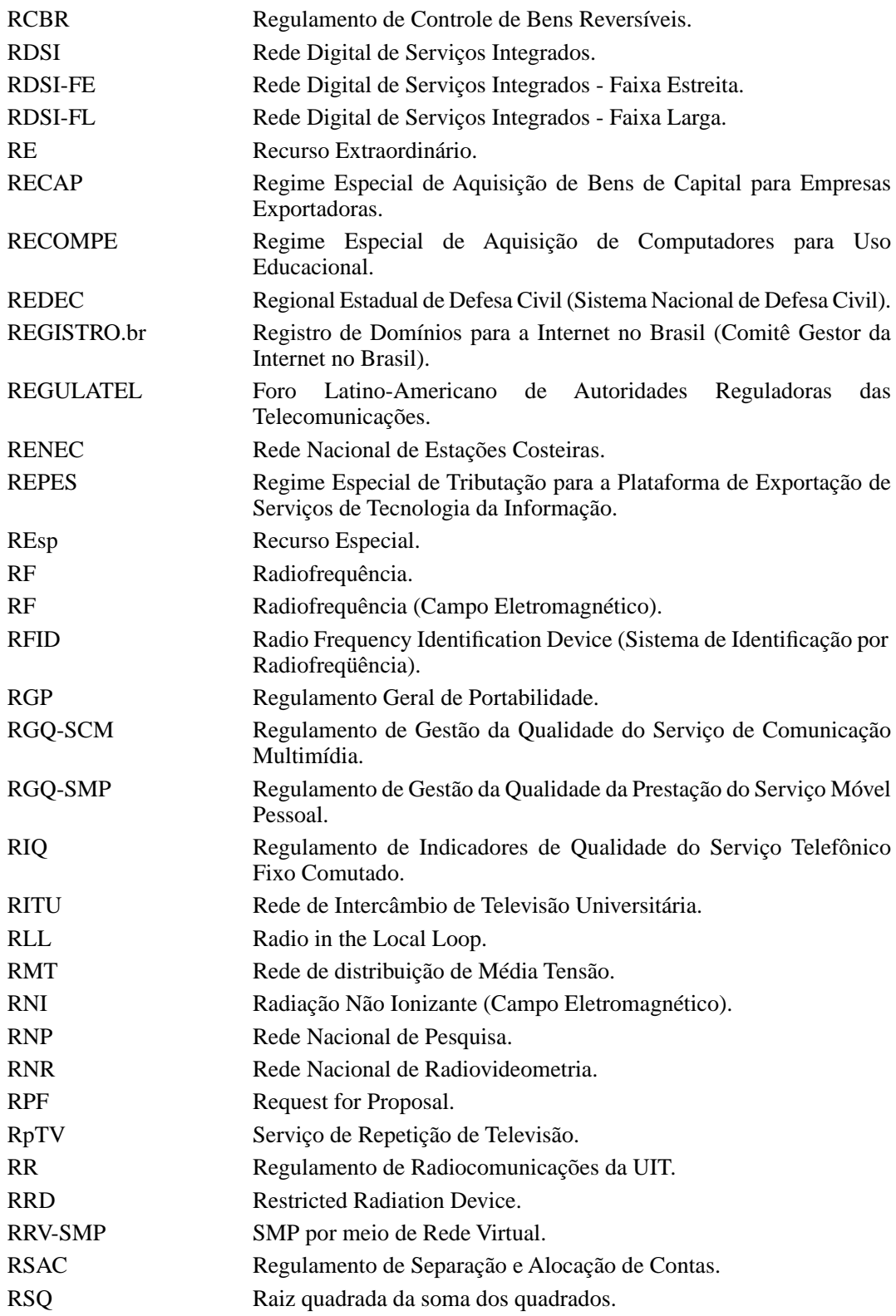




\section{RTFM}

RTV

RVU-M

SA

SAC

SAC

SACP

SAM

SAMU

SAP

SAPN

SAR

SARC

SART

SATVA

SBC

SBPJOR

SBRD

SBTVD

SBTVD-T

SCI

SCM

SCMa

SCR

SDE

SDK

SeAC

SEAE

SECEX

SEDH

SEFID

SELIC

SER

SERDS

SETA

SFS

SGAL
Regulamento Técnico para Emissoras de Radiodifusão Sonora em Frequência Modulada.

Serviço de Retransmissão de Televisão.

Valor de Referência de VU-M.

Specific Absorption (Absorção Específica).

Serviço de Atendimento ao Consumidor.

Stand Alone Cost (Custo Total Individual - Separação e Alocação de Contas).

Sistema de Acompanhamento de Consulta Pública.

Serviço Avançado de Mensagens.

Serviço de Atendimento Móvel de Urgência.

Secondary Audio Programming (Programa Secundário de Áudio).

Sistema de Administração dos Recursos de Numeração.

Specific Absorption Rate (Taxa de Absorção Específica).

Serviço Auxiliar de Radiodifusão e Correlatos.

Transponder de busca e salvamento.

Sistema de Acompanhamento das Obrigações das Prestadoras de TV por Assinatura.

Sistema Brasileiro de Certificação.

Sociedade Brasileira de Pesquisadores em Jornalismo.

Sistema Brasileiro de Rádio Digital.

Sistema Brasileiro de Televisão Digital.

Sistema Brasileiro de Televisão Digital Terrestre.

Serviço de Conexão à INTERNET.

Serviço de Comunicação Multimídia.

Serviço de Comunicação de Massa por assinatura.

Serviço de Comunicações de Interesse Restrito.

Secretaria de Direito Econômico (Ministério da Justiça).

Software Development Kit.

Serviço de Acesso Condicionado.

Secretaria de Acompanhamento Econômico (Ministério da Fazenda).

Secretaria de Controle Externo (Tribunal de Contas da União).

Secretaria Especial de Direitos Humanos da Presidência da República.

Secretaria de Fiscalização de Desestatização (Tribunal de Contas da União).

Sistema Especial de Liquidação e Custódia.

Serviço Especial de Radiochamada.

Serviço Especial de Radiodeterminação por Satélite.

Sindicato Nacional das Empresas Operadoras de Sistemas de Televisão por Assinatura (Representação empresarial).

Serviço Fixo por Satélite.

Sistema de Gerenciamento de Áreas Locais. 
SGB

SGB

SGIQ

SGME

SGT.1

SHF

SI

SIAD

SIAFI

SICAP

SICOM

SIGAnatel

SIGEC

SINAMOB

SINAPI/IBGE

SINAR

SINCAB

SINDEC

SINDER

SINDESB

SINDISAT

SINDITELEBRASIL

SINSTAL

SINTEIS

SIT

SITARWEB

SLD

SLDA

SLDD

SLDT

SLE
Sistema Geodésico Brasileiro.

Sistema Geoestacionário Brasileiro.

Sistema de Gerenciamento de Indicadores de Qualidade.

Sistema de Gestão e Monitoragem do Espectro.

Subgrupo de Trabalho $n^{\circ} 1$ - Comunicações do Mercosul.

Super High Frequency.

Sociedade da Informação.

Sistema Integrado de Apoio à Decisão (Programa para obtenção dos Valores de Eficiência DEA).

Sistema Integrado de Administração Financeira do Governo Federal. Sistema de Controle de Rastreamento de Documentos e Processos.

Sistema de Comunicação de Governo do Poder Executivo (Publicidade da Administração Pública Federal).

Sistema de Informações Geográficas do Brasil.

Sistema Integrado de Gestão de Créditos da ANATEL.

Sistema Nacional de Mobilização.

Sistema Nacional de Pesquisa de Custos e Índices da Construção Civil.

Sistema Nacional de Arquivos.

Sindicato Nacional dos Trabalhadores em Sistemas de TV por Assinatura e Serviços Especiais de Telecomunicações (Representação profissional).

Sistema Nacional de Defesa Civil.

Sindicato Nacional das Empresas de Radiocomunicações (Representação empresarial).

Sistema de Informações sobre Desastres no Brasil (Sistema Nacional de Defesa Civil).

Sindicato Nacional das Empresas de Telecomunicações por Satélite (Representação empresarial).

Sindicato Nacional das Empresas Operadoras de Serviços de Telecomunicações (Representação empresarial).

Sindicato Nacional das Empresas Instaladoras de Sistemas e Redes de TV por Assinatura e Telecomunicações (Representação empresarial).

Sindicatos Estaduais dos Trabalhadores em Telecomunicações (Representação profissional).

Sistema com Transponder Interrogador.

Sistema de Informações Técnicas para Administração das Radiocomunicações WEB.

Serviço por Linha Dedicada.

Serviço por Linha Dedicada para Sinais Analógicos.

Serviço por Linha Dedicada para Sinais Digitais.

Serviço por Linha Dedicada para Sinais Telegráficos.

Serviço Limitado Especializado. 
SLMP

SLP

SLPR

SMA

SMC

SMD

SME

SMGS

SMM

SMP

SMS

SMS

SMT

SNC

SNDC

Socicom

SOCINE

SPV

SRA

SRD

SRE

SRT

SRTT

SSB

STE

STEL

STF

STFC

STJ

STM

STP

STS

SUFRAMA

SVA

TAB

TAP

TAP

TAP

TBSMC
Serviço Limitado Móvel Privativo.

Serviço Limitado Privado.

Serviço Limitado Privado de Radiochamada.

Serviço Móvel Aeronáutico (R, em rota; OR, fora de rota)..

Serviço Móvel Celular.

Surface Mounted Device.

Serviço Móvel Especializado.

Serviço Móvel Global por Satélite.

Serviço Móvel Marítimo.

Serviço Móvel Pessoal.

Serviço Móvel por Satélite.

Short Message Service.

Surface Mounted Technology.

Secretaria Nacional de Comunicações (MINFRA).

Sistema Nacional de Defesa do Consumidor.

Federação Brasileira das Associações Científicas e Acadêmicas de Comunicação.

Sociedade Brasileira de Estudos de Cinema.

Superintendência de Serviços Privados.

Serviço de Radiocomunicação Aeronáutica Público-Restrito.

Short Range Device.

Serviço de Radiotáxi Especializado.

Serviço de Radiotáxi.

Serviço de Rede de Transporte de Telecomunicações.

Single Side Band 'Modulation' (Modulação em Faixa Lateral Simples).

Secretaria de Telecomunicações (Ministério das Comunicações).

Sistema de Serviços de Telecomunicações.

Supremo Tribunal Federal.

Serviço Telefônico Fixo Comutado Destinado ao Uso do Público em Geral.

Superior Tribunal de Justiça.

Superior Tribunal Militar.

Serviço Telefônico Público (em desuso).

Serviço de Transporte de Sinais de Telecomunicações por Satélite.

Superintendência da Zona Franca de Manaus.

Serviço de Valor Adicionado.

Tarifa Aduaneira do Brasil.

Television Association of Programmers (Estados Unidos da América).

Terminal de Acesso Público.

Terminal de Acesso Público (Serviço Telefônico Fixo Comutado).

Tarifa Básica do Serviço Móvel Celular. 
TCD

TCP

TCU

TDD

TDMA

TEB

TEC

TelComp

TELEBRÁS

TELEBRASIL

TELEX

TFEL

TFF

TFI

THD

TIC

TICs

TIPI

TISA

TMC

TME

TMN

TOE

TR

TRD

TRF

TRF1

TRI

TRX

TSC

TSC

TSE

TST

TT

TU

TU-COM

TU-M

TU-RIU

TU-RIU1
Termo de Compromisso de Desempenho.

Transport Control Protocol (INTERNET).

Tribunal de Contas da União.

Time Division Duplexing (Duplexação por Divisão no Tempo).

Time Division Multiple Access (Múltiplo Acesso por Divisão em Tempo).

Taxa de Erro de Bits.

Tarifa Externa Comum.

Associação Brasileira das Prestadoras de Serviços de Telecomunicações Competitivas.

Telecomunicações Brasileiras S.A..

Associação Brasileira de Telecomunicações.

Comutação Telegráfica.

Thin-Film Electroluminescent (Displays Eletroluminescentes a Filme Fino).

Taxa de Fiscalização do Funcionamento.

Taxa de Fiscalização da Instalação.

Distorção harmônica total.

Tecnologias da Informação e Comunicação.

Tecnologias de Informação e Comunicação.

Tabela de Incidência do Imposto sobre Produtos Industrializados.

Traveller Information Services Association.

- Traffic Message Channel (Canal de Mensagem de Trânsito).

Tarifa de Mudança de Endereço (Serviço Telefônico Fixo Comutado).

Telecommunications Management Network.

Taxa de Onda.

Taxa Referencial.

Taxa Referencial Diária.

Tribunal Regional Federal.

Tribunal Regional Federal da $1^{a}$ Região.

Termo de Responsabilidade de Instalação.

Transceptor.

Terminal Móvel de Acesso a Ser Certificado.

Terminal Portátil a Ser Certificado.

Tribunal Superior Eleitoral.

Tribunal Superior do Trabalho.

Tronco/Canal Telefônico de Entrada.

Tarifa de Uso.

Tarifa de Uso de Comutação.

Tarifa de Uso Móvel.

Tarifa de Uso de Rede Interurbana.

Tarifa de Uso de Rede Interurbana Nível 1. 
TU-RIU2

TU-RL

TUP

TUP

TVA

TVA

TVC

UAC

UCS

UHF

UIT

UIT-R

UIT-R-SA

ULEPICC

UMB

UMTS

UNE-P

UNICEF

UO

UPS

UR

URA

URA

URA

URV

USG

UTP

UTRAN

UWB

UWIA

VBI

$\mathrm{VC}$

VC-1

VC-2

VC-3
Tarifa de Uso de Rede Interurbana Nível 2.

Tarifa de Uso de Rede Local.

Telefone de Uso Público.

Telefone de Uso Público (Serviço Telefônico Fixo Comutado).

Serviço Especial de Televisão por Assinatura.

Televisão por Assinatura (Espécie de Serviço Especial).

TV a Cabo.

Unidade de Atendimento de Cooperativa.

Unidade de Controle do Sistema (Sistemas de Acesso sem Fio do STFC).

Ultra High Frequency (Freqüência Ultra Alta).

União Internacional de Telecomunicações (Union Internationale des Télécommunications / Unión Internacional de Telecommunicaciones).

Setor de Radiocomunicações da União Internacional de Telecomunicações.

Recomendações da UIT sobre Aplicações Espaciais e Meteorologia.

Unión Latina de Economía Política de la Información, la Comunicación y la Cultura.

Ultra Mobile Broadband.

Universal Mobile Telecommunications Service (Rede celular 3G).

Desagregação de Plataforma.

United Nations Children's Fund (Fundo das Nações Unidas para a Infância).

Unidade Operacional.

Uninterruptable Power Supply.

Unidade Retificadora.

Unidade de Resposta Audível (SMP - Gestão da Qualidade).

Unidade de Resposta Automática.

Unidade Remota de Assinante.

Unidade Real de Valor.

Unidade de Supervisão e Gerência (Sistemas de Acesso sem Fio do STFC).

Unidade de Tarifação para TUP e TAP (Serviço Telefônico Fixo Comutado).

Universal Terrestrial Radio Access Network.

Ultrawideband.

Ubiquitous Wireless Internet Access.

Vertical Blanking Interval (Intervalo de Apagamento Vertical).

Valor de Comunicação (Serviço Telefônico Fixo Comutado).

Valor de Comunicação 1.

Valor de Comunicação 2.

Valor de Comunicação 3. 
VC-T

VC-VST-R

VC1

VCA

VELOX

VHF

VIGP

VLF

VPA

Vpe

Vpe

VSAT

VSWR

VTP

VU-M

VU-M

VU-T

WACC

WAN

WAP

WCDMA

WDM

WDMA

Wi-Fi

WIMAX

WiMesh

WISP

WLAN

WLL

WMAN

WSIS

WTPF-09

WTPF-09

xDSL

$\theta$ ini
Valor de Comunicação (Serviço Móvel Especializado).

Valor de Comunicação do Visitante em Roaming.

Valor de Comunicação 1 (Serviço Móvel Pessoal).

Valor de Chamada Atendida (Serviço Telefônico Fixo Comutado).

Serviço de acesso à internet de banda larga comercializado pela empresa Oi.

Very High Frequency (Frequiência Muito Alta).

Variação do Índice Geral de Preços - Disponibilidade Interna.

Very Low Frequency.

Valor Patrimonial da Ação.

Volt por elemento.

Volts por elemento.

Very Small Aperture Terminal (Certificação).

Relação de Onda Estacionária.

Valor da Unidade de Tarifação para TUP e TAP (Serviço Telefônico Fixo Comutado).

Valor de Remuneração de Uso de Rede do SMP.

Valor de Uso de Rede Móvel.

Valor de Remuneração de Uso de Rede do SME.

Weighted Average Cost of Capital (Custo Médio Ponderado de Capital na Separação e Alocação de Contas).

Wide Area Network.

Wireless Application Protocol.

Wideband CDMA (CDMA de banda larga).

Wavelength Division Multiplexing (Multiplexação por Divisão de Comprimento de Onda).

Wavelegth Division Multiple Access (Acesso Múltiplo por Divisão de Comprimento de Onda).

Wireless Fidelity (padrão IEEE 802.11).

Worldwide Interoperability for Microwave Access.

WiMesh - Wireless Mesh.

Wireless Internet Service Provider.

Wireless Local Area Network.

Wireless Local Loop (Rede Local sem Fio).

Wireless Metropolitan Area Network.

World Summit on the Information Society (Cúpula Mundial sobre a Sociedade da Informação - CMSI).

Fórum Mundial sobre Políticas de Telecomunicações.

World Telecommunication Policy Forum.

x Digital Subscriber Line.

Ângulo Teta Inicial. 


\section{Normas e Atos de 2011}

\section{Fundamentos}

\section{Aspectos Históricos}

Atos

Tr Relatório Anual da ANATEL 2010

\section{Infraestrutura e Recursos do Setor de Telecomunicações}

\section{Equipamentos de Telecomunicações}

\section{Normatização}

Resolução da ANATEL $\mathbf{n}^{\circ}$ 571, de 28 de setembro de 2011 - Aprova o Regulamento para definição de formatos e tolerâncias para dados geodésicos fornecidos à Anatel.

\section{Antenas}

\section{Normatização}

Resolução da ANATEL no 572, de 28 de setembro de 2011 - Aprova a Norma para Certificação e Homologação de Antenas de Estações Terrenas Operando com Satélites Geoestacionários.

\section{Estações de Telecomunicações}

Normatização

Resolução da ANATEL no 572, de 28 de setembro de 2011 - Aprova a Norma para Certificação e Homologação de Antenas de Estações Terrenas Operando com Satélites Geoestacionários.

\section{Certificação / Homologação}

\section{Normatização}

Resolução da ANATEL $\mathbf{n}^{\circ}$ 570, de 22 de agosto de 2011 - Aprova o Regulamento para Certificação e Homologação de Acumuladores ChumboÁcido Estacionários Regulados por Válvula. 
Resolução da ANATEL n 572, de 28 de setembro de 2011 - Aprova a Norma para Certificação e Homologação de Antenas de Estações Terrenas Operando com Satélites Geoestacionários.

\section{Espectro de Radiofrequência}

Atribuição, Destinação e Designação de Radiofrequência

Normatização

Resolução da ANATEL n ${ }^{0}$ 561, de 28 de janeiro de 2011 - Aprova Alteração do Regulamento sobre Condições de Uso de Radiofrequências nas Faixas de $25,35 \mathrm{GHz}$ a $28,35 \mathrm{GHz}, 29,10 \mathrm{GHz}$ a $29,25 \mathrm{GHz}$ e $31,00 \mathrm{GHz}$ a $31,30 \mathrm{GHz}$.

- Alteração do Regulamento sobre Condições de Uso de Radiofrequências nas Faixas de $25,35 \mathrm{GHz}$ a $28,35 \mathrm{GHz}, 29,10 \mathrm{GHz}$ a $29,25 \mathrm{GHz}$ e $31,00 \mathrm{GHz}$ a $31,30 \mathrm{GHz}$.

Atos

Ato do Conselho Diretor da ANATEL no 2.282, de 15 de abril de 2011 Aprova a Edição 2011 do Plano de Atribuição, Destinação e Distribuição de Faixas de Frequiências no Brasil.

Condições de Uso de Radiofrequência e Canalização (Distribuição de Canais)

Normatização

Resolução da ANATEL n ${ }^{0}$ 561, de 28 de janeiro de 2011 - Aprova Alteração do Regulamento sobre Condições de Uso de Radiofrequências nas Faixas de $25,35 \mathrm{GHz}$ a $28,35 \mathrm{GHz}, 29,10 \mathrm{GHz}$ a $29,25 \mathrm{GHz}$ e $31,00 \mathrm{GHz}$ a $31,30 \mathrm{GHz}$.

- Alteração do Regulamento sobre Condições de Uso de Radiofrequências nas Faixas de $25,35 \mathrm{GHz}$ a $28,35 \mathrm{GHz}, 29,10 \mathrm{GHz}$ a $29,25 \mathrm{GHz}$ e $31,00 \mathrm{GHz}$ a $31,30 \mathrm{GHz}$.

Resolução da ANATEL no ${ }^{068}$, de 15 de junho de 2011 - Republica, com alterações, o Regulamento sobre Canalização e Condições de Uso de Radiofrequências na Faixa de $148 \mathrm{MHz}$ a $174 \mathrm{MHz}$.

\section{Órbita e Satélite}

Atos

乐 Súmula da ANATEL $\mathbf{n}^{\circ}$ 10, de 15 de março de 2011 - A legislação de telecomunicações não impede a indicação de mais de um representante legal 
pela exploradora de satélite estrangeiro. O representante legal da Exploradora de Satélite Estrangeiro pode ser prestadora de serviço de telecomunicações. Caso a prestadora de serviço de telecomunicações pretenda fazer uso da capacidade espacial que ela própria representa, a contratação deverá ser formalizada por intermédio de outro representante legal. O contrato de comercialização de capacidade espacial decorrente do direito de exploração de satélite estrangeiro deve ser firmado no Brasil entre o representante legal da exploradora e a prestadora de serviço de telecomunicações, partes contratuais distintas.

\section{Administração do Setor de Telecomunicações}

\section{Fiscalização das Telecomunicações}

\section{Normatização}

Lei $\mathrm{n}^{\circ}$ 12.529, de 30 de novembro de 2011 - Estrutura o Sistema Brasileiro de Defesa da Concorrência; dispõe sobre a prevenção e repressão às infrações contra a ordem econômica; altera a Lei $\mathrm{n}^{\circ}$ 8.137, de 27 de dezembro de 1990, o Decreto-Lei no 3.689, de 3 de outubro de 1941 - Código de Processo Penal, e a Lei $n^{\circ} 7.347$, de 24 de julho de 1985; revoga dispositivos da Lei $n^{\circ} 8.884$, de 11 de junho de 1994, e a Lei n$^{\circ} 9.781$, de 19 de janeiro de 1999; e dá outras providências.

Portaria MC $\mathbf{n}^{\mathbf{0}}$ 462, de 14 de outubro de 2011 - Aprova a Norma Complementar $n^{\circ}$ 1/2011 - Serviço de Radiodifusão Comunitária.

Anexo - Norma Complementar no 1/2011 - Serviço de Radiodifusão Comunitária

Portaria MC no 69, de 17 de março de 2011 - Altera o Regimento Interno do Ministério das Comunicações aprovado pela Portaria n $^{\circ} 401$, de 22 de agosto de 2006.

Resolução da ANATEL $\mathbf{n}^{\circ}$ 571, de 28 de setembro de 2011 - Aprova o Regulamento para definição de formatos e tolerâncias para dados geodésicos fornecidos à Anatel.

\section{Atos}

רR Portaria do Ministério das Comunicações n 69/2011 - Altera o Regimento Interno do Ministério das Comunicações aprovado pela Portaria $n^{\circ} 401$, de 22 de agosto de 2006.

Súmula da ANATEL n $^{\circ}$ 12, de 19 de dezembro de 2011 - Não cabe recurso contra ato administrativo que determine ou formalize a instauração de processo administrativo sancionador. 


\section{Liberdade de Participação}

\section{Atos}

থT Portaria ANATEL n 941, de 28 de outubro de 2011 - Dispõe sobre o acesso pelo público em geral aos documentos e informações acostados em Procedimento de Apuração de Descumprimento de Obrigações (Pado) e dá outras providências.

\section{Tributação no Setor de Telecomunicações}

\section{Normatização}

Lei $\mathbf{n}^{\mathbf{0}}$ 12.431, de 24 de junho de 2011 - Dispõe sobre a incidência do imposto sobre a renda nas operações que especifica; altera as Leis nos 11.478 , de 29 de maio de 2007, 6.404, de 15 de dezembro de 1976, 9.430, de 27 de dezembro de 1996, 12.350, de 20 de dezembro de 2010, 11.196, de 21 de novembro de 2005, 8.248, de 23 de outubro de 1991, 9.648, de 27 de maio de 1998, 11.943, de 28 de maio de 2009, 9.808, de 20 de julho de 1999, 10.260, de 12 de julho de 2001, 11.096, de 13 de janeiro de 2005, 11.180, de 23 de setembro de 2005 , 11.128, de 28 de junho de 2005, 11.909, de 4 de março de 2009, 11.371, de 28 de novembro de 2006, 12.249, de 11 de junho de 2010, 10.150, de 21 de dezembro de 2000, 10.312, de 27 de novembro de 2001, e 12.058, de 13 de outubro de 2009, e o Decreto-Lei no 288, de 28 de fevereiro de 1967; institui o Regime Especial de Incentivos para o Desenvolvimento de Usinas Nucleares (Renuclear); dispõe sobre medidas tributárias relacionadas ao Plano Nacional de Banda Larga; altera a legislação relativa à isenção do Adicional ao Frete para Renovação da Marinha Mercante (AFRMM); dispõe sobre a extinção do Fundo Nacional de Desenvolvimento; e dá outras providências.

Lei $\mathrm{n}^{\circ}$ 12.507, de 11 de outubro de 2011 - Altera o art. 28 da Lei $n^{\circ} 11.196$, de 21 de novembro de 2005, para incluir no Programa de Inclusão Digital tablet PC produzido no País conforme processo produtivo básico estabelecido pelo Poder Executivo; altera as Leis $\mathrm{n}^{\circ} 10.833$, de 29 de dezembro de 2003, $\mathrm{n}^{\mathrm{o}} 11.482$, de 31 de maio de 2007, no 11.508 , de 20 de julho de 2007, e n ${ }^{\circ} 8.212$, de 24 de julho de 1991; e revoga dispositivo da Medida Provisória n ${ }^{\circ}$ 540, de 2 de agosto de 2011.

\section{Outorgas}

\section{Espécies de Outorga}

\section{Concessão (regras aplicáveis)}

\section{Normatização}

Lei $\mathbf{n}^{\circ}$ 12.485, de 12 de setembro de 2011 - Dispõe sobre a comunicação audiovisual de acesso condicionado; altera a Medida Provisória no 2.228-1, de 6 de setembro de 2001, e as Leis $n^{\circ}$ s 11.437, de 28 de dezembro de 2006, 5.070, 
de 7 de julho de 1966, 8.977, de 6 de janeiro de 1995, e 9.472, de 16 de julho de 1997; e dá outras providências.

Anexo - Anexo I da Medida Provisória nº 2.228-1, de 6 de setembro de 2001.

A possibilidade de concessionárias explorarem mais de um serviço de telecomunicações decorreu da nova redação ao art. 86 da Lei Geral de Telecomunicações por força da Lei 12.485/2011, que disciplinou a comunicação audiovisual de acesso condicionado.

Decreto $n^{0}$ 7.512, de 30 de junho de 2011 - Aprova o Plano Geral de Metas para a Universalização do Serviço Telefônico Fixo Comutado Prestado no Regime Público - PGMU, e dá outras providências.

Anexo 1 - Anexo 1 ao Decreto $n^{\circ} 7.512$, de 30 de junho de 2011 - Plano Geral de Metas para a Universalização do Serviço Telefônico Fixo Comutado Prestado no Regime Público - PGMU

Anexo 2 - Telefones de Uso Público - Concessionárias do STFC na Modalidade Local

Anexo 3 - Telefones de Uso Público - Concessionária do STFC nas Modalidades Longa Distância Nacional e Internacional

Resolução da ANATEL n $^{\circ}$ 565, de 26 de abril de 2011 - Aprova a alteração dos Contratos de Concessão para a prestação do Serviço Telefônico Fixo Comutado - STFC, nas modalidades de serviço Local, Longa Distância Nacional - LDN e Longa Distância Internacional - LDI.

Resolução da ANATEL no 577, de 24 de novembro de 2011 - Altera o Anexo I do Regulamento de Tarifação do Serviço Telefônico Fixo Comutado Destinado ao Uso do Público em Geral - STFC prestado no Regime Público, aprovado pela Resolução $n^{\circ} 424$, de 6 de dezembro de 2005, bem como o Anexo II à Resolução no 263, de 8 de junho de 2001, Plano Geral de Códigos Nacionais, anexo ao Regulamento de Numeração do STFC, aprovado pela Resolução $\mathrm{n}^{\circ}$ 86, de 30 de dezembro de 1998.

Atos

Ato da Superintendência de Radiofrequencia e Fiscalização e da Superintendência de Serviços Públicos da ANATEL $n^{0} 162$, de 6 de janeiro de 2011 - Determinação à Empresa Brasileira de Telecomunicações S.A. para que efetue inventário físico do seu patrimônio, bem como a Relação de Bens Reversíveis consistente com o Inventário atualizado do seu patrimônio.

Ato da Superintendência de Radiofrequencia e Fiscalização e da Superintendência de Serviços Públicos da ANATEL no 160, de 6 de janeiro de 2011 - Determinação à Brasil Telecom para que efetue inventário físico do seu patrimônio, bem como Relação de Bens Reversíveis consistente com o Inventário atualizado do seu patrimônio 
Ato da Superintendência de Radiofrequencia e Fiscalização e da Superintendência de Serviços Públicos da ANATEL no 161, de 6 de janeiro de 2011 - Determinação à Telemar Note Leste S.A. para que efetue inventário físico do seu patrimônio, bem como a Relação de Bens Reversíveis consistente com o Inventário atualizado do seu patrimônio.

\section{Planos de Serviços}

\section{Normatização}

Resolução da ANATEL no 577, de 24 de novembro de 2011 - Altera o Anexo I do Regulamento de Tarifação do Serviço Telefônico Fixo Comutado Destinado ao Uso do Público em Geral - STFC prestado no Regime Público, aprovado pela Resolução $n^{\circ} 424$, de 6 de dezembro de 2005, bem como o Anexo II à Resolução n 263, de 8 de junho de 2001, Plano Geral de Códigos Nacionais, anexo ao Regulamento de Numeração do STFC, aprovado pela Resolução $\mathrm{n}^{\circ}$ 86, de 30 de dezembro de 1998.

\section{Políticas de Telecomunicações}

\section{Política Tarifária}

\section{Normatização}

Resolução da ANATEL no 573, de 10 de outubro de 2011 - Aprova a Norma para Implantação e Acompanhamento de Liberdade Tarifária no Serviço Telefônico Fixo Comutado Destinado ao Uso Público em Geral, Modalidade Longa Distância Internacional.

Resolução da ANATEL n 576, de 31 de outubro de 2011 - Aprova o Regulamento sobre Critérios de Reajuste das Tarifas das Chamadas do Serviço Telefônico Fixo Comutado (STFC) envolvendo acessos do Serviço Móvel Pessoal (SMP) ou do Serviço Móvel Especializado (SME).

Resolução da ANATEL no 577, de 24 de novembro de 2011 - Altera o Anexo I do Regulamento de Tarifação do Serviço Telefônico Fixo Comutado Destinado ao Uso do Público em Geral - STFC prestado no Regime Público, aprovado pela Resolução $n^{\circ} 424$, de 6 de dezembro de 2005, bem como o Anexo II à Resolução no 263, de 8 de junho de 2001, Plano Geral de Códigos Nacionais, anexo ao Regulamento de Numeração do STFC, aprovado pela Resolução $n^{\circ}$ 86, de 30 de dezembro de 1998. 


\title{
Política Industrial
}

\author{
Normatização
}

Lei $\mathbf{n}^{0}$ 12.431, de 24 de junho de 2011 - Dispõe sobre a incidência do imposto sobre a renda nas operações que especifica; altera as Leis nos 11.478 , de 29 de maio de 2007, 6.404, de 15 de dezembro de 1976, 9.430, de 27 de dezembro de 1996, 12.350, de 20 de dezembro de 2010, 11.196, de 21 de novembro de 2005, 8.248, de 23 de outubro de 1991, 9.648, de 27 de maio de 1998, 11.943, de 28 de maio de 2009, 9.808, de 20 de julho de 1999, 10.260, de 12 de julho de 2001, 11.096, de 13 de janeiro de 2005, 11.180, de 23 de setembro de 2005, 11.128, de 28 de junho de 2005, 11.909 , de 4 de março de 2009, 11.371, de 28 de novembro de 2006, 12.249, de 11 de junho de 2010, 10.150, de 21 de dezembro de 2000, 10.312, de 27 de novembro de 2001, e 12.058, de 13 de outubro de 2009, e o Decreto-Lei no 288, de 28 de fevereiro de 1967; institui o Regime Especial de Incentivos para o Desenvolvimento de Usinas Nucleares (Renuclear); dispõe sobre medidas tributárias relacionadas ao Plano Nacional de Banda Larga; altera a legislação relativa à isenção do Adicional ao Frete para Renovação da Marinha Mercante (AFRMM); dispõe sobre a extinção do Fundo Nacional de Desenvolvimento; e dá outras providências.

Lei $n^{\mathbf{0}}$ 12.507, de 11 de outubro de 2011 - Altera o art. 28 da Lei $n^{\circ} 11.196$, de 21 de novembro de 2005, para incluir no Programa de Inclusão Digital tablet PC produzido no País conforme processo produtivo básico estabelecido pelo Poder Executivo; altera as Leis $\mathrm{n}^{\circ} 10.833$, de 29 de dezembro de 2003, $\mathrm{n}^{\mathrm{o}} 11.482$, de 31 de maio de 2007, $n^{\circ} 11.508$, de 20 de julho de 2007, e $n^{\circ} 8.212$, de 24 de julho de 1991; e revoga dispositivo da Medida Provisória n $^{\circ} 540$, de 2 de agosto de 2011.

\section{Concorrência no Setor de Telecomunicações}

\section{- Concorrência no Setor de Telecomunicações}

O Serviço de Comunicação Multimídia apresenta-se como serviço convergente com pretensão de introduzir utilidades concorrentes às fornecidas por serviços tradicionais do setor.

\section{Normatização}

Lei $\mathrm{n}^{\circ}$ 12.529, de 30 de novembro de 2011 - Estrutura o Sistema Brasileiro de Defesa da Concorrência; dispõe sobre a prevenção e repressão às infrações contra a ordem econômica; altera a Lei $\mathrm{n}^{\circ}$ 8.137, de 27 de dezembro de 1990, o Decreto-Lei n ${ }^{\circ} 3.689$, de 3 de outubro de 1941 - Código de Processo Penal, e a Lei $n^{\circ} 7.347$, de 24 de julho de 1985; revoga dispositivos da Lei $n^{\circ} 8.884$, de 11 de junho de 1994, e a Lei no 9.781, de 19 de janeiro de 1999; e dá outras providências.

Decreto $\mathbf{n}^{\circ}$ 7.628, de 30 de novembro de 2011 - Aprova o Programa de Dispêndios Globais - PDG para 2012 das empresas estatais federais, e dá outras providências. 
Resolução da ANATEL n 573, de 10 de outubro de 2011 - Aprova a Norma para Implantação e Acompanhamento de Liberdade Tarifária no Serviço Telefônico Fixo Comutado Destinado ao Uso Público em Geral, Modalidade Longa Distância Internacional.

\section{Atos}

Ato do Conselho Diretor da ANATEL n $^{\circ}$ 1.970, de $1^{\circ}$ de abril de 2011 Anuência prévia à reestruturação societária decorrente da aquisição da Vivo pela Telefônica.

\section{Anexo}

Ato do Conselho Diretor da ANATEL no 5.703, de 16 de agosto de 2011 Anuência prévia à incorporação da VIVO TELECOMUNICAÇÕES S/A pela TELECOMUNICAÇÕES DE SÃO PAULO S/A - TELESP.

\section{Universalização e Massificação}

\section{Normatização}

Lei $n^{0}$ 12.431, de 24 de junho de 2011 - Dispõe sobre a incidência do imposto sobre a renda nas operações que especifica; altera as Leis nos 11.478 , de 29 de maio de 2007, 6.404, de 15 de dezembro de 1976, 9.430, de 27 de dezembro de 1996, 12.350, de 20 de dezembro de 2010, 11.196, de 21 de novembro de 2005, 8.248, de 23 de outubro de 1991, 9.648, de 27 de maio de 1998, 11.943, de 28 de maio de 2009, 9.808 , de 20 de julho de $1999,10.260$, de 12 de julho de 2001, 11.096, de 13 de janeiro de 2005, 11.180, de 23 de setembro de 2005, 11.128, de 28 de junho de 2005, 11.909, de 4 de março de 2009, 11.371, de 28 de novembro de 2006, 12.249, de 11 de junho de 2010, 10.150, de 21 de dezembro de 2000, 10.312, de 27 de novembro de 2001, e 12.058, de 13 de outubro de 2009, e o Decreto-Lei no 288, de 28 de fevereiro de 1967; institui o Regime Especial de Incentivos para o Desenvolvimento de Usinas Nucleares (Renuclear); dispõe sobre medidas tributárias relacionadas ao Plano Nacional de Banda Larga; altera a legislação relativa à isenção do Adicional ao Frete para Renovação da Marinha Mercante (AFRMM); dispõe sobre a extinção do Fundo Nacional de Desenvolvimento; e dá outras providências.

\section{Acesso às Telecomunicações}

\section{Normatização}

Portaria MC no 376, de 19 de agosto de 2011 - Institui o Projeto de Implantação e Manutenção das Cidades Digitais. 


\section{Educação e Pesquisa}

\section{Normatização}

Portaria MC no 376, de 19 de agosto de 2011 - Institui o Projeto de Implantação e Manutenção das Cidades Digitais.

\section{Metas de Universalização}

\section{Normatização}

Decreto $\mathbf{n}^{\mathbf{0}}$ 7.512, de 30 de junho de 2011 - Aprova o Plano Geral de Metas para a Universalização do Serviço Telefônico Fixo Comutado Prestado no Regime Público - PGMU, e dá outras providências.

Anexo 1 - Anexo 1 ao Decreto $n^{\circ} 7.512$, de 30 de junho de 2011 - Plano Geral de Metas para a Universalização do Serviço Telefônico Fixo Comutado Prestado no Regime Público - PGMU

Anexo 2 - Telefones de Uso Público - Concessionárias do STFC na Modalidade Local

Anexo 3 - Telefones de Uso Público - Concessionária do STFC nas Modalidades Longa Distância Nacional e Internacional

Resolução da ANATEL n ${ }^{0}$ 569, de 5 de agosto de 2011 - Aprova a prorrogação dos prazos estabelecidos nos arts. 12, 17 e 18 do Regulamento de Acompanhamento e Controle das Obrigações de Universalização do Serviço Telefônico Fixo Comutado destinado ao uso do público geral - STFC, aprovado pela Resolução n ${ }^{\circ} 536$, de 9 de novembro de 2009, para o ano de 2011, e a alteração do referido regulamento, para incluir novo dispositivo (art. 23).

\section{Pesquisa \& Desenvolvimento}

\section{Normatização}

Portaria MC no 376, de 19 de agosto de 2011 - Institui o Projeto de Implantação e Manutenção das Cidades Digitais.

\section{Qualidade do Serviço}

\section{Normatização}

Resolução da ANATEL n⿳ 567, de 24 de maio de 2011 - Aprova alteração do Regulamento do Serviço Telefônico Fixo Comutado, aprovado pela Resolução no 426, de 2005; do Regulamento do Serviço Móvel Pessoal, aprovado pela Resolução n 477, de 2007; e do Regulamento de Proteção e Defesa dos Direitos dos Assinantes dos Serviços de Televisão por Assinatura, aprovado pela Resolução no 488, de 2007, e alterado pela Resolução no 528, de 2009. Anexo - Alteração do Regulamento do Serviço Telefônico Fixo Comutado 
Resolução da ANATEL no 574, de 28 de outubro de 2011 - Aprova o Regulamento de Gestão da Qualidade do Serviço de Comunicação Multimídia (RGQ-SCM).

Resolução da ANATEL $\mathbf{n}^{0}$ 575, de 28 de outubro de 2011 - Aprova o Regulamento de Gestão da Qualidade da Prestação do Serviço Móvel Pessoal - RGQ-SMP e altera o Regulamento do Serviço Móvel Pessoal - SMP, aprovado pela Resolução $n^{\circ} 477$, de 7 de agosto de 2007, e alterado pelas Resoluções $n^{\circ}$ 491 , de 12 de fevereiro de 2008, $\mathrm{n}^{\circ} 509$, de 14 de agosto de $2008, \mathrm{n}^{\circ} 564$, de 20 de abril de 2011 e n⿳0 567, de 24 de maio de 2011.

\section{Controle Social, Hierárquico e Interorgânico}

\section{Normatização}

Lei $\mathbf{n}^{\circ}$ 12.527, de 18 de novembro de 2011 - Regula o acesso a informações previsto no inciso XXXIII do art. $5^{\circ}$, no inciso II do $\S 3^{\circ}$ do art. 37 e no $\S 2^{\circ}$ do art. 216 da Constituição Federal; altera a Lei $n^{\circ} 8.112$, de 11 de dezembro de 1990; revoga a Lei $\mathrm{n}^{\mathbf{0}} 11.111$, de 5 de maio de 2005, e dispositivos da Lei $\mathrm{n}^{\mathbf{o}}$ 8.159 , de 8 de janeiro de 1991; e dá outras providências.

Resolução da ANATEL n $\mathbf{n}^{\circ}$ 567, de 24 de maio de 2011 - Aprova alteração do Regulamento do Serviço Telefônico Fixo Comutado, aprovado pela Resolução n 426, de 2005; do Regulamento do Serviço Móvel Pessoal, aprovado pela Resolução no 477, de 2007; e do Regulamento de Proteção e Defesa dos Direitos dos Assinantes dos Serviços de Televisão por Assinatura, aprovado pela Resolução n 488, de 2007, e alterado pela Resolução no 528, de 2009.

Anexo - Alteração do Regulamento do Serviço Telefônico Fixo Comutado

\section{Atos}

Portaria ANATEL n⿳ 941, de 28 de outubro de 2011 - Dispõe sobre o acesso pelo público em geral aos documentos e informações acostados em Procedimento de Apuração de Descumprimento de Obrigações (Pado) e dá outras providências.

Relatório Anual da ANATEL 2010

\section{Sigilo em Telecomunicações}

\section{Normatização}

Lei $\mathbf{n}^{\circ}$ 12.527, de 18 de novembro de 2011 - Regula o acesso a informações previsto no inciso XXXIII do art. $5^{\circ}$, no inciso II do $\S 3^{\circ}$ do art. 37 e no $\S 2^{\circ}$ do art. 216 da Constituição Federal; altera a Lei ${ }^{\circ} 8.112$, de 11 de dezembro de 1990; revoga a Lei $\mathrm{n}^{\circ} 11.111$, de 5 de maio de 2005, e dispositivos da Lei $\mathrm{n}^{\mathrm{o}}$ 8.159 , de 8 de janeiro de 1991; e dá outras providências. 


\section{Atos}

R Portaria ANATEL n ${ }^{\circ}$ 941, de 28 de outubro de 2011 - Dispõe sobre o acesso pelo público em geral aos documentos e informações acostados em Procedimento de Apuração de Descumprimento de Obrigações (Pado) e dá outras providências.

\section{Convergência}

\section{Normatização}

Portaria $M C \mathrm{n}^{\circ}$ 491, de 23 de novembro de 2011 - Altera a Portaria $n^{\circ}$ 652, de 10 de outubro de 2006.

\section{Classificações de Serviços no Setor de Telecomunicações}

\section{Quanto ao Regime Jurídico de Prestação}

\section{Serviço Prestado em Regime Público}

Normatização

Resolução da ANATEL no 573, de 10 de outubro de 2011 - Aprova a Norma para Implantação e Acompanhamento de Liberdade Tarifária no Serviço Telefônico Fixo Comutado Destinado ao Uso Público em Geral, Modalidade Longa Distância Internacional.

\section{Quanto ao Gênero}

\section{Serviço Limitado}

\section{Serviço Limitado Privado}

\section{Normatização}

Resolução da ANATEL $n^{\circ}$ 568, de 15 de junho de 2011 - Republica, com alterações, o Regulamento sobre Canalização e Condições de Uso de Radiofrequências na Faixa de $148 \mathrm{MHz}$ a $174 \mathrm{MHz}$.

\section{Serviço de Valor Adicionado}

\section{Normatização}

Resolução no 4, de 16 de setembro de 2011 - Reafirma o entendimento do CGI.br sobre a natureza do serviço de conexão à internet. 


\section{Quanto à Perspectiva Convergente}

\section{Comunicação Multimídia}

Normatização

Resolução da ANATEL $\mathbf{n}^{\circ}$ 574, de 28 de outubro de 2011 - Aprova o Regulamento de Gestão da Qualidade do Serviço de Comunicação Multimídia (RGQ-SCM).

Resolução da ANATEL no 575, de 28 de outubro de 2011 - Aprova o Regulamento de Gestão da Qualidade da Prestação do Serviço Móvel Pessoal - RGQ-SMP e altera o Regulamento do Serviço Móvel Pessoal - SMP, aprovado pela Resolução $n^{\circ} 477$, de 7 de agosto de 2007, e alterado pelas Resoluções $n^{\circ}$ 491 , de 12 de fevereiro de $2008, n^{\circ} 509$, de 14 de agosto de $2008, n^{\circ} 564$, de 20 de abril de 2011 e n ${ }^{\circ} 567$, de 24 de maio de 2011.

\section{Comunicação de Massa}

\section{Normatização}

Lei $n^{\circ}$ 12.485, de 12 de setembro de 2011 - Dispõe sobre a comunicação audiovisual de acesso condicionado; altera a Medida Provisória no 2.228-1, de 6 de setembro de 2001, e as Leis $n^{\circ}$ s 11.437 , de 28 de dezembro de 2006, 5.070, de 7 de julho de 1966, 8.977, de 6 de janeiro de 1995, e 9.472, de 16 de julho de 1997; e dá outras providências.

Anexo - Anexo I da Medida Provisória nº 2.228-1, de 6 de setembro de 2001.

Reunião dos serviços de TV a Cabo (TVC), MMDS, DTH e TVA sob a nomenclatura abrangente de Serviço de Acesso Condicionado.

\section{Serviços no Setor de Telecomunicações}

\section{Serviço Telefônico Fixo Comutado (STFC)}

\section{Normatização}

Lei $n^{0}$ 12.485, de 12 de setembro de 2011 - Dispõe sobre a comunicação audiovisual de acesso condicionado; altera a Medida Provisória no 2.228-1, de 6 de setembro de 2001, e as Leis n's 11.437, de 28 de dezembro de 2006, 5.070, de 7 de julho de 1966, 8.977, de 6 de janeiro de 1995, e 9.472, de 16 de julho de 1997; e dá outras providências.

Anexo - Anexo I da Medida Provisória nº 2.228-1, de 6 de setembro de 2001.

A Lei 12.485/2011, no seu art. 37, § 18, prevê que a concessionária de STFC poderá solicitar, a qualquer tempo, a adequação do contrato de concessão para 
eliminação das restrições que vedem a possibilidade de que a concessionária do serviço e suas coligadas, controladas ou controladoras prestem serviço de TVC, inclusive nas áreas geográficas de prestação do serviço objeto da referida concessão.

Decreto $\mathbf{n}^{\mathbf{0}}$ 7.512, de 30 de junho de 2011 - Aprova o Plano Geral de Metas para a Universalização do Serviço Telefônico Fixo Comutado Prestado no Regime Público - PGMU, e dá outras providências.

Anexo 1 - Anexo 1 ao Decreto $n^{\circ} 7.512$, de 30 de junho de 2011 - Plano Geral de Metas para a Universalização do Serviço Telefônico Fixo Comutado Prestado no Regime Público - PGMU

Anexo 2 - Telefones de Uso Público - Concessionárias do STFC na Modalidade Local

Anexo 3 - Telefones de Uso Público - Concessionária do STFC nas Modalidades Longa Distância Nacional e Internacional

Resolução da ANATEL $\mathbf{n}^{\circ}$ 560, de 21 de janeiro de 2011 - Aprova o Regulamento sobre Áreas Locais para o Serviço Telefônico Fixo Comutado Destinado ao Uso do Público em Geral - STFC.

Anexo - Regulamento sobre Áreas Locais para o Serviço Telefônico Fixo Comutado Destinado ao Uso do Público em Geral - STFC.

Resolução da ANATEL no 561, de 28 de janeiro de 2011 - Aprova Alteração do Regulamento sobre Condições de Uso de Radiofrequências nas Faixas de $25,35 \mathrm{GHz}$ a $28,35 \mathrm{GHz}, 29,10 \mathrm{GHz}$ a $29,25 \mathrm{GHz}$ e $31,00 \mathrm{GHz}$ a $31,30 \mathrm{GHz}$.

- Alteração do Regulamento sobre Condições de Uso de Radiofrequências nas Faixas de 25,35 GHz a 28,35 GHz, 29,10 GHz a 29,25 GHz e $31,00 \mathrm{GHz}$ a $31,30 \mathrm{GHz}$.

Resolução da ANATEL no 565, de 26 de abril de 2011 - Aprova a alteração dos Contratos de Concessão para a prestação do Serviço Telefônico Fixo Comutado - STFC, nas modalidades de serviço Local, Longa Distância Nacional - LDN e Longa Distância Internacional - LDI.

Resolução da ANATEL n 567, de 24 de maio de 2011 - Aprova alteração do Regulamento do Serviço Telefônico Fixo Comutado, aprovado pela Resolução n 426, de 2005; do Regulamento do Serviço Móvel Pessoal, aprovado pela Resolução no 477, de 2007; e do Regulamento de Proteção e Defesa dos Direitos dos Assinantes dos Serviços de Televisão por Assinatura, aprovado pela Resolução no 488, de 2007, e alterado pela Resolução nº 528, de 2009.

Anexo - Alteração do Regulamento do Serviço Telefônico Fixo Comutado

Resolução da ANATEL no 568, de 15 de junho de 2011 - Republica, com alterações, o Regulamento sobre Canalização e Condições de Uso de Radiofrequências na Faixa de $148 \mathrm{MHz}$ a $174 \mathrm{MHz}$.

Resolução da ANATEL n $^{\circ}$ 569, de 5 de agosto de 2011 - Aprova a prorrogação dos prazos estabelecidos nos arts. 12, 17 e 18 do Regulamento de Acompanhamento e Controle das Obrigações de Universalização do Serviço 
Telefônico Fixo Comutado destinado ao uso do público geral - STFC, aprovado pela Resolução no 536, de 9 de novembro de 2009, para o ano de 2011, e a alteração do referido regulamento, para incluir novo dispositivo (art. 23).

Resolução da ANATEL n 573, de 10 de outubro de 2011 - Aprova a Norma para Implantação e Acompanhamento de Liberdade Tarifária no Serviço Telefônico Fixo Comutado Destinado ao Uso Público em Geral, Modalidade Longa Distância Internacional.

Resolução da ANATEL n 577, de 24 de novembro de 2011 - Altera o Anexo I do Regulamento de Tarifação do Serviço Telefônico Fixo Comutado Destinado ao Uso do Público em Geral - STFC prestado no Regime Público, aprovado pela Resolução $n^{\circ} 424$, de 6 de dezembro de 2005, bem como o Anexo II à Resolução n ${ }^{\circ}$ 263, de 8 de junho de 2001, Plano Geral de Códigos Nacionais, anexo ao Regulamento de Numeração do STFC, aprovado pela Resolução no 86, de 30 de dezembro de 1998.

\section{Atos}

Ato da Superintendência de Radiofrequencia e Fiscalização e da Superintendência de Serviços Públicos da ANATEL nº 162, de 6 de janeiro de 2011 - Determinação à Empresa Brasileira de Telecomunicações S.A. para que efetue inventário físico do seu patrimônio, bem como a Relação de Bens Reversíveis consistente com o Inventário atualizado do seu patrimônio.

Ato da Superintendência de Radiofrequencia e Fiscalização e da Superintendência de Serviços Públicos da ANATEL no 160, de 6 de janeiro de 2011 - Determinação à Brasil Telecom para que efetue inventário físico do seu patrimônio, bem como Relação de Bens Reversíveis consistente com o Inventário atualizado do seu patrimônio

Ato da Superintendência de Radiofrequencia e Fiscalização e da Superintendência de Serviços Públicos da ANATEL n 161, de 6 de janeiro de 2011 - Determinação à Telemar Note Leste S.A. para que efetue inventário físico do seu patrimônio, bem como a Relação de Bens Reversíveis consistente com o Inventário atualizado do seu patrimônio.

Súmula da ANATEL no 11, de 17 de novembro de 2011 - Estão incluídas na base de cálculo do ônus contratual previsto nos Contratos de Concessão de 2006/2010, para prestação do STFC, dentre outras, as receitas de interconexão, PUC, e, ainda, de outros serviços adicionais e receitas operacionais inerentes ao STFC. 


\title{
Serviço Móvel Pessoal (SMP)
}

\author{
Normatização
}

Resolução da ANATEL n⿳ 567, de 24 de maio de 2011 - Aprova alteração do Regulamento do Serviço Telefônico Fixo Comutado, aprovado pela Resolução n 426, de 2005; do Regulamento do Serviço Móvel Pessoal, aprovado pela Resolução n 477, de 2007; e do Regulamento de Proteção e Defesa dos Direitos dos Assinantes dos Serviços de Televisão por Assinatura, aprovado pela Resolução n 488, de 2007, e alterado pela Resolução nº 528, de 2009.

Anexo - Alteração do Regulamento do Serviço Telefônico Fixo Comutado

\section{Serviço de Comunicação Multimída (SCM)}

\section{Normatização}

Resolução da ANATEL no 561, de 28 de janeiro de 2011 - Aprova Alteração do Regulamento sobre Condições de Uso de Radiofrequências nas Faixas de $25,35 \mathrm{GHz}$ a $28,35 \mathrm{GHz}, 29,10 \mathrm{GHz}$ a $29,25 \mathrm{GHz}$ e $31,00 \mathrm{GHz}$ a $31,30 \mathrm{GHz}$.

- Alteração do Regulamento sobre Condições de Uso de Radiofrequências nas Faixas de 25,35 GHz a 28,35 GHz, 29,10 GHz a 29,25 GHz e $31,00 \mathrm{GHz}$ a $31,30 \mathrm{GHz}$.

Resolução da ANATEL $\mathbf{n}^{\circ}$ 574, de 28 de outubro de 2011 - Aprova o Regulamento de Gestão da Qualidade do Serviço de Comunicação Multimídia (RGQ-SCM).

Resolução da ANATEL $\mathbf{n}^{\circ}$ 575, de 28 de outubro de 2011 - Aprova o Regulamento de Gestão da Qualidade da Prestação do Serviço Móvel Pessoal - RGQ-SMP e altera o Regulamento do Serviço Móvel Pessoal - SMP, aprovado pela Resolução $n^{\circ} 477$, de 7 de agosto de 2007, e alterado pelas Resoluções $\mathbf{n}^{\circ}$ 491, de 12 de fevereiro de 2008, $\mathrm{n}^{\circ} 509$, de 14 de agosto de 2008, $\mathrm{n}^{\circ} 564$, de 20 de abril de 2011 e n⿳ 567 , de 24 de maio de 2011.

\section{TV a Cabo}

\section{Normatização}

Lei $\mathrm{n}^{\circ}$ 12.485, de 12 de setembro de 2011 - Dispõe sobre a comunicação audiovisual de acesso condicionado; altera a Medida Provisória no 2.228-1, de 6 de setembro de 2001, e as Leis $n^{\circ} \mathrm{s} 11.437$, de 28 de dezembro de 2006, 5.070, de 7 de julho de 1966, 8.977, de 6 de janeiro de 1995, e 9.472, de 16 de julho de 1997; e dá outras providências.

Anexo - Anexo I da Medida Provisória n 2.228-1, de 6 de setembro de 2001. 
Resolução da ANATEL n⿳ 567, de 24 de maio de 2011 - Aprova alteração do Regulamento do Serviço Telefônico Fixo Comutado, aprovado pela Resolução n 426, de 2005; do Regulamento do Serviço Móvel Pessoal, aprovado pela Resolução n 477, de 2007; e do Regulamento de Proteção e Defesa dos Direitos dos Assinantes dos Serviços de Televisão por Assinatura, aprovado pela Resolução n 488, de 2007, e alterado pela Resolução nº 528, de 2009.

Anexo - Alteração do Regulamento do Serviço Telefônico Fixo Comutado

\section{TVA (Serviço Especial de TV por Assinatura)}

\section{Normatização}

Lei $n^{0}$ 12.485, de 12 de setembro de 2011 - Dispõe sobre a comunicação audiovisual de acesso condicionado; altera a Medida Provisória no 2.228-1, de 6 de setembro de 2001, e as Leis $n^{\circ} \mathrm{s} 11.437$, de 28 de dezembro de 2006, 5.070, de 7 de julho de 1966, 8.977, de 6 de janeiro de 1995, e 9.472, de 16 de julho de 1997; e dá outras providências.

Anexo - Anexo I da Medida Provisória nº 2.228-1, de 6 de setembro de 2001.

Resolução da ANATEL n⿳ 567, de 24 de maio de 2011 - Aprova alteração do Regulamento do Serviço Telefônico Fixo Comutado, aprovado pela Resolução no 426, de 2005; do Regulamento do Serviço Móvel Pessoal, aprovado pela Resolução n ${ }^{\circ}$ 477, de 2007; e do Regulamento de Proteção e Defesa dos Direitos dos Assinantes dos Serviços de Televisão por Assinatura, aprovado pela Resolução no 488, de 2007, e alterado pela Resolução nº 528, de 2009.

Anexo - Alteração do Regulamento do Serviço Telefônico Fixo Comutado

\section{DTH (Direct to Home - Serviço de Distribuição de Sinais de Televisão e de Áudio por Assinatura Via Satélite)}

\section{Normatização}

Lei $\mathbf{n}^{\circ}$ 12.485, de 12 de setembro de 2011 - Dispõe sobre a comunicação audiovisual de acesso condicionado; altera a Medida Provisória no 2.228-1, de 6 de setembro de 2001, e as Leis $n^{\circ}$ s 11.437, de 28 de dezembro de 2006, 5.070, de 7 de julho de 1966, 8.977, de 6 de janeiro de 1995, e 9.472, de 16 de julho de 1997; e dá outras providências.

Anexo - Anexo I da Medida Provisória nº 2.228-1, de 6 de setembro de 2001.

Resolução da ANATEL no 563, de 30 de março de 2011 - Alteração na Destinação das Faixas de Radiofrequências de $12,2 \mathrm{GHz}$ a $12,7 \mathrm{GHz}$ e de 17,3 $\mathrm{GHz}$ a $17,7 \mathrm{GHz}$.

Resolução da ANATEL $n^{\circ}$ 567, de 24 de maio de 2011 - Aprova alteração do Regulamento do Serviço Telefônico Fixo Comutado, aprovado pela Resolução n 426, de 2005; do Regulamento do Serviço Móvel Pessoal, aprovado pela Resolução n 477, de 2007; e do Regulamento de Proteção e Defesa dos Direitos dos Assinantes dos Serviços de Televisão por Assinatura, aprovado pela Resolução n 488, de 2007, e alterado pela Resolução nº 528, de 2009. 
Anexo - Alteração do Regulamento do Serviço Telefônico Fixo Comutado

\section{MMDS (Multichannel Multipoint Distribution Service - Serviço de Distribuição de Sinais Multiponto Multicanal)}

\section{Normatização}

Lei $\mathbf{n}^{\circ} \mathbf{1 2 . 4 8 5}$, de 12 de setembro de 2011 - Dispõe sobre a comunicação audiovisual de acesso condicionado; altera a Medida Provisória no 2.228-1, de 6 de setembro de 2001, e as Leis $n^{\circ}$ s 11.437, de 28 de dezembro de 2006, 5.070, de 7 de julho de 1966, 8.977, de 6 de janeiro de 1995, e 9.472, de 16 de julho de 1997; e dá outras providências.

Anexo - Anexo I da Medida Provisória n ${ }^{\circ}$ 2.228-1, de 6 de setembro de 2001.

Resolução da ANATEL $\mathbf{n}^{\circ}$ 567, de 24 de maio de 2011 - Aprova alteração do Regulamento do Serviço Telefônico Fixo Comutado, aprovado pela Resolução n 426, de 2005; do Regulamento do Serviço Móvel Pessoal, aprovado pela Resolução n 477, de 2007; e do Regulamento de Proteção e Defesa dos Direitos dos Assinantes dos Serviços de Televisão por Assinatura, aprovado pela Resolução no 488, de 2007, e alterado pela Resolução no 528, de 2009.

Anexo - Alteração do Regulamento do Serviço Telefônico Fixo Comutado

Atos

Ato do Conselho Diretor da ANATEL no 5.156, de 22 de julho de 2011 Aprova o modelo de Termo de Autorização do Serviço de Distribuição de Sinais Multiponto Multicanal (MMDS).

Anexo - Modelo de Termo de Autorização do Serviço de Distribuição de Sinais Multiponto Multicanal (MMDS)

\section{Serviço Rádio do Cidadão}

\section{Normatização}

Resolução da ANATEL $\mathbf{n}^{\circ}$ 578, de 30 de novembro de 2011 - Aprova o Regulamento do Serviço Rádio do Cidadão.

\section{Radiodifusão}

\section{Normatização}

Lei $\mathbf{n}^{\circ}$ 12.485, de 12 de setembro de 2011 - Dispõe sobre a comunicação audiovisual de acesso condicionado; altera a Medida Provisória no 2.228-1, de 6 de setembro de 2001, e as Leis $n^{\circ} \mathrm{s} 11.437$, de 28 de dezembro de 2006, 5.070, de 7 de julho de 1966, 8.977, de 6 de janeiro de 1995, e 9.472, de 16 de julho de 1997; e dá outras providências.

Anexo - Anexo I da Medida Provisória nº 2.228-1, de 6 de setembro de 2001. 
A Lei $12.485 / 2011$, art. $1^{\circ}$, parágrafo único, exclue do seu campo de aplicação os serviços de radiodifusão sonora e de sons e imagens, ressalvados os dispositivos que expressamente façam menção a esses serviços ou a suas prestadoras.

Portaria MC no 256, de 6 de julho de 2011 - Dispõe sobre a análise de pedido de outorga para a execução dos serviços de radiodifusão sonora e de sons e imagens, com fins exclusivamente educativos.

Portaria MC no 420, de 14 de setembro de 2011 - Dispõe sobre o procedimento para outorga dos serviços de radiodifusão sonora e de sons e imagens, com fins exclusivamente educativos.

Anexo - Documentos necessários à instrução das propostas das pessoas jurídicas de direito público interno, em original ou cópia autenticada.

Portaria MC no 69, de 17 de março de 2011 - Altera o Regimento Interno do Ministério das Comunicações aprovado pela Portaria $n^{\circ} 401$, de 22 de agosto de 2006.

Portaria MC no 491, de 23 de novembro de 2011 - Altera a Portaria ${ }^{\circ} 652$, de 10 de outubro de 2006.

Portaria MC no 498, de 5 de dezembro de 2011 - Aprova a Norma de Procedimentos de Autorização para a Execução do Serviço de Retransmissão de Televisão e do Serviço de Repetição de Televisão, ancilares ao Serviço de Radiodifusão de Sons e Imagens

Anexo - Norma de Procedimentos de Autorização para a Execução do Serviço de Retransmissão de Televisão e do Serviço de Repetição de Televisão

Portaria MC no 561, de 22 de dezembro de 2011 - Altera a Norma de Procedimentos de Autorização para a Execução do Serviço de Retransmissão de Televisão e do Serviço de Repetição de Televisão, aprovada pela Portaria $\mathrm{n}^{\circ}$ 498, de 5 de dezembro de 2011.

Resolução da ANATEL no 563, de 30 de março de 2011 - Alteração na Destinação das Faixas de Radiofrequências de 12,2 GHz a 12,7 GHz e de 17,3 $\mathrm{GHz}$ a $17,7 \mathrm{GHz}$.

Atos

Portaria do Ministério das Comunicações n 69/2011 - Altera o Regimento Interno do Ministério das Comunicações aprovado pela Portaria $n^{\circ} 401$, de 22 de agosto de 2006.

\section{Radiodifusão Comunitária}

\section{Normatização}

Portaria MC n' 462, de 14 de outubro de 2011 - Aprova a Norma Complementar $\mathrm{n}^{\circ}$ 1/2011 - Serviço de Radiodifusão Comunitária.

Anexo - Norma Complementar $n^{\circ}$ 1/2011 - Serviço de Radiodifusão Comunitária 


\section{Serviço Auxiliar de Radiodifusão e Correlatos (SARC)}

Normatização

Portaria MC no 69, de 17 de março de 2011 - Altera o Regimento Interno do Ministério das Comunicações aprovado pela Portaria $n^{\circ} 401$, de 22 de agosto de 2006.

Atos

Portaria do Ministério das Comunicações no 69/2011 - Altera o Regimento Interno do Ministério das Comunicações aprovado pela Portaria ${ }^{\circ} 401$, de 22 de agosto de 2006.

\section{Serviço de Radiotáxi}

\section{Normatização}

Resolução da ANATEL $\mathbf{n}^{\circ}$ 568, de 15 de junho de 2011 - Republica, com alterações, o Regulamento sobre Canalização e Condições de Uso de Radiofrequências na Faixa de $148 \mathrm{MHz}$ a $174 \mathrm{MHz}$.

\section{Serviço Móvel Marítimo}

\section{Normatização}

Resolução da ANATEL n ${ }^{0}$ 568, de 15 de junho de 2011 - Republica, com alterações, o Regulamento sobre Canalização e Condições de Uso de Radiofrequências na Faixa de $148 \mathrm{MHz}$ a $174 \mathrm{MHz}$.

\section{Serviço Limitado Privado}

\section{Normatização}

Resolução da ANATEL n ${ }^{0}$ 561, de 28 de janeiro de 2011 - Aprova Alteração do Regulamento sobre Condições de Uso de Radiofrequências nas Faixas de $25,35 \mathrm{GHz}$ a $28,35 \mathrm{GHz}, 29,10 \mathrm{GHz}$ a $29,25 \mathrm{GHz}$ e $31,00 \mathrm{GHz}$ a $31,30 \mathrm{GHz}$.

- Alteração do Regulamento sobre Condições de Uso de Radiofrequências nas Faixas de $25,35 \mathrm{GHz}$ a $28,35 \mathrm{GHz}, 29,10 \mathrm{GHz}$ a $29,25 \mathrm{GHz}$ e $31,00 \mathrm{GHz}$ a $31,30 \mathrm{GHz}$. 


\title{
Serviço de Telefonia Rural
}

\author{
Normatização
}

Resolução da ANATEL no 568, de 15 de junho de 2011 - Republica, com alterações, o Regulamento sobre Canalização e Condições de Uso de Radiofrequências na Faixa de $148 \mathrm{MHz}$ a $174 \mathrm{MHz}$.

\section{Serviço de Acesso Condicionado}

\section{Normatização}

Lei $n^{\circ}$ 12.485, de 12 de setembro de 2011 - Dispõe sobre a comunicação audiovisual de acesso condicionado; altera a Medida Provisória no 2.228-1, de 6 de setembro de 2001, e as Leis $n^{\circ}$ s 11.437 , de 28 de dezembro de 2006, 5.070, de 7 de julho de 1966, 8.977, de 6 de janeiro de 1995, e 9.472, de 16 de julho de 1997; e dá outras providências.

Anexo - Anexo I da Medida Provisória nº 2.228-1, de 6 de setembro de 2001.

\section{Ramos Jurídicos Afins}

\section{Direito do Consumidor}

\section{Normatização}

Resolução da ANATEL n 567, de 24 de maio de 2011 - Aprova alteração do Regulamento do Serviço Telefônico Fixo Comutado, aprovado pela Resolução no 426, de 2005; do Regulamento do Serviço Móvel Pessoal, aprovado pela Resolução no 477, de 2007; e do Regulamento de Proteção e Defesa dos Direitos dos Assinantes dos Serviços de Televisão por Assinatura, aprovado pela Resolução no 488, de 2007, e alterado pela Resolução no 528, de 2009.

Anexo - Alteração do Regulamento do Serviço Telefônico Fixo Comutado

\section{Direito da Concorrência}

\section{Normatização}

Lei $\mathrm{n}^{\circ}$ 12.529, de 30 de novembro de 2011 - Estrutura o Sistema Brasileiro de Defesa da Concorrência; dispõe sobre a prevenção e repressão às infrações contra a ordem econômica; altera a Lei $\mathrm{n}^{\circ}$ 8.137, de 27 de dezembro de 1990, o Decreto-Lei no 3.689, de 3 de outubro de 1941 - Código de Processo Penal, e a Lei $n^{\circ} 7.347$, de 24 de julho de 1985; revoga dispositivos da Lei $n^{\circ} 8.884$, de 11 de junho de 1994, e a Lei n$^{\circ} 9.781$, de 19 de janeiro de 1999; e dá outras providências. 
Atos

Ato do Conselho Diretor da ANATEL $\mathbf{n}^{\circ} 1.970$, de $1^{\circ}$ de abril de 2011 Anuência prévia à reestruturação societária decorrente da aquisição da Vivo pela Telefônica.

\section{Anexo}

Ato do Conselho Diretor da ANATEL no ${ }^{\circ .703, ~ d e ~} 16$ de agosto de 2011 Anuência prévia à incorporação da VIVO TELECOMUNICAÇÕES S/A pela TELECOMUNICAÇÕES DE SÃO PAULO S/A - TELESP.

\section{Direito Administrativo}

\section{Atos}

Súmula da ANATEL n ${ }^{0}$ 12, de 19 de dezembro de 2011 - Não cabe recurso contra ato administrativo que determine ou formalize a instauração de processo administrativo sancionador.

\section{Aplicações de Telecomunicações}

\section{Aplicações Educacionais}

\section{Normatização}

Portaria MC $\mathrm{n}^{0}$ 256, de 6 de julho de 2011 - Dispõe sobre a análise de pedido de outorga para a execução dos serviços de radiodifusão sonora e de sons e imagens, com fins exclusivamente educativos.

Portaria MC $\mathbf{n}^{0}$ 420, de 14 de setembro de 2011 - Dispõe sobre o procedimento para outorga dos serviços de radiodifusão sonora e de sons e imagens, com fins exclusivamente educativos.

Anexo - Documentos necessários à instrução das propostas das pessoas jurídicas de direito público interno, em original ou cópia autenticada.

\section{Internet}

\section{Normatização}

Lei no 12.431, de 24 de junho de 2011 - Dispõe sobre a incidência do imposto sobre a renda nas operações que especifica; altera as Leis nos 11.478, de 29 de maio de 2007, 6.404, de 15 de dezembro de 1976, 9.430, de 27 de dezembro de 1996, 12.350, de 20 de dezembro de 2010, 11.196, de 21 de novembro de 2005, 8.248, de 23 de outubro de 1991, 9.648, de 27 de maio de 1998, 11.943, de 28 de maio de 2009, 9.808, de 20 de julho de 1999, 10.260, de 12 de julho de 2001, 11.096, de 13 de janeiro de 2005, 11.180, de 23 de setembro de 2005, 11.128 , de 28 de junho de 2005, 11.909 , de 4 de março de 2009, 11.371, de 28 de novembro de 2006, 12.249, de 11 de junho de 2010, 10.150, de 21 de dezembro de 2000, 10.312, de 27 de novembro de 2001, e 12.058, de 13 de 
outubro de 2009, e o Decreto-Lei no 288, de 28 de fevereiro de 1967; institui o Regime Especial de Incentivos para o Desenvolvimento de Usinas Nucleares (Renuclear); dispõe sobre medidas tributárias relacionadas ao Plano Nacional de Banda Larga; altera a legislação relativa à isenção do Adicional ao Frete para Renovação da Marinha Mercante (AFRMM); dispõe sobre a extinção do Fundo Nacional de Desenvolvimento; e dá outras providências.

Resolução n* 4, de 16 de setembro de 2011 - Reafirma o entendimento do CGI.br sobre a natureza do serviço de conexão à internet.

\section{Acesso a Serviços de Interesse Público e Uso de Radiofrequência por tais Serviços}

\section{Normatização}

Resolução da ANATEL no 564, de 20 de abril de 2011 - Aprova alteração no Regulamento do Serviço Móvel Pessoal - SMP, aprovado pela Resolução $\mathrm{n}^{\circ} 477$, de 7 de agosto de 2007, e alterado pelas Resoluções $n^{\circ} 491$, de 12 de fevereiro de 2008, e no 509 , de 14 de agosto de 2008.

\section{Anexo}

\section{Banda Larga}

\section{Normatização}

Lei $\mathrm{n}^{\mathbf{0}}$ 12.431, de 24 de junho de 2011 - Dispõe sobre a incidência do imposto sobre a renda nas operações que especifica; altera as Leis nos 11.478 , de 29 de maio de 2007, 6.404, de 15 de dezembro de 1976, 9.430, de 27 de dezembro de 1996, 12.350, de 20 de dezembro de 2010, 11.196, de 21 de novembro de 2005, 8.248, de 23 de outubro de 1991, 9.648, de 27 de maio de 1998, 11.943, de 28 de maio de 2009, 9.808 , de 20 de julho de 1999, 10.260, de 12 de julho de 2001, 11.096, de 13 de janeiro de 2005, 11.180, de 23 de setembro de 2005 , 11.128, de 28 de junho de 2005, 11.909, de 4 de março de 2009, 11.371, de 28 de novembro de 2006, 12.249, de 11 de junho de 2010, 10.150, de 21 de dezembro de 2000, 10.312, de 27 de novembro de 2001, e 12.058, de 13 de outubro de 2009, e o Decreto-Lei no 288, de 28 de fevereiro de 1967; institui o Regime Especial de Incentivos para o Desenvolvimento de Usinas Nucleares (Renuclear); dispõe sobre medidas tributárias relacionadas ao Plano Nacional de Banda Larga; altera a legislação relativa à isenção do Adicional ao Frete para Renovação da Marinha Mercante (AFRMM); dispõe sobre a extinção do Fundo Nacional de Desenvolvimento; e dá outras providências.

Resolução da ANATEL no 574, de 28 de outubro de 2011 - Aprova o Regulamento de Gestão da Qualidade do Serviço de Comunicação Multimídia (RGQ-SCM).

Resolução da ANATEL $\mathbf{n}^{\circ}$ 575, de 28 de outubro de 2011 - Aprova o Regulamento de Gestão da Qualidade da Prestação do Serviço Móvel Pessoal 
- RGQ-SMP e altera o Regulamento do Serviço Móvel Pessoal - SMP, aprovado pela Resolução $n^{\circ} 477$, de 7 de agosto de 2007, e alterado pelas Resoluções $n^{\circ}$ 491, de 12 de fevereiro de 2008, n ${ }^{\circ} 509$, de 14 de agosto de 2008, $n^{\circ} 564$, de 20 de abril de 2011 e n ${ }^{\circ} 567$, de 24 de maio de 2011.

\section{Atores no Setor de Telecomunicações}

\section{ANATEL}

\section{Normatização}

Lei $\mathrm{n}^{\mathbf{0}}$ 12.527, de 18 de novembro de 2011 - Regula o acesso a informações previsto no inciso XXXIII do art. $5^{\circ}$, no inciso II do $\S 3^{\circ}$ do art. 37 e no $\S 2^{\circ}$ do art. 216 da Constituição Federal; altera a Lei $n^{\circ} 8.112$, de 11 de dezembro de 1990; revoga a Lei $n^{\circ} 11.111$, de 5 de maio de 2005, e dispositivos da Lei $n^{\circ}$ 8.159 , de 8 de janeiro de 1991; e dá outras providências.

\section{Atos}

ح下 Portaria ANATEL n 941, de 28 de outubro de 2011 - Dispõe sobre o acesso pelo público em geral aos documentos e informações acostados em Procedimento de Apuração de Descumprimento de Obrigações (Pado) e dá outras providências.

\section{Relatório Anual da ANATEL 2010}

Súmula da ANATEL $n^{\circ}$ 12, de 19 de dezembro de 2011 - Não cabe recurso contra ato administrativo que determine ou formalize a instauração de processo administrativo sancionador.

\section{CADE}

\section{Normatização}

Lei $n^{\circ}$ 12.529, de 30 de novembro de 2011 - Estrutura o Sistema Brasileiro de Defesa da Concorrência; dispõe sobre a prevenção e repressão às infrações contra a ordem econômica; altera a Lei no 8.137, de 27 de dezembro de 1990, o Decreto-Lei no 3.689, de 3 de outubro de 1941 - Código de Processo Penal, e a Lei $\mathrm{n}^{\circ} 7.347$, de 24 de julho de 1985; revoga dispositivos da Lei $\mathrm{n}^{\circ} 8.884$, de 11 de junho de 1994, e a Lei nº 9.781, de 19 de janeiro de 1999; e dá outras providências. 


\section{Poder Executivo}

\section{Presidência da República}

\section{Normatização}

Decreto no 7.512, de 30 de junho de 2011 - Aprova o Plano Geral de Metas para a Universalização do Serviço Telefônico Fixo Comutado Prestado no Regime Público - PGMU, e dá outras providências.

Anexo 1 - Anexo 1 ao Decreto $n^{\circ} 7.512$, de 30 de junho de 2011 - Plano Geral de Metas para a Universalização do Serviço Telefônico Fixo Comutado Prestado no Regime Público - PGMU

Anexo 2 - Telefones de Uso Público - Concessionárias do STFC na Modalidade Local

Anexo 3 - Telefones de Uso Público - Concessionária do STFC nas Modalidades Longa Distância Nacional e Internacional

\section{Ministério da Justiça}

\section{Normatização}

Lei $\mathbf{n}^{\circ}$ 12.485, de 12 de setembro de 2011 - Dispõe sobre a comunicação audiovisual de acesso condicionado; altera a Medida Provisória no 2.228-1, de 6 de setembro de 2001, e as Leis $n^{\circ}$ s 11.437, de 28 de dezembro de 2006, 5.070, de 7 de julho de 1966, 8.977, de 6 de janeiro de 1995, e 9.472, de 16 de julho de 1997; e dá outras providências.

Anexo - Anexo I da Medida Provisória no 2.228-1, de 6 de setembro de 2001.

$\checkmark$ Previsão legal de compulsória classificação informativa do natureza do conteúdo e das faixas etárias recomendadas para o Serviço de Acesso Condicionado.

\section{Ministério das Comunicações}

\section{Normatização}

Portaria MC no 462, de 14 de outubro de 2011 - Aprova a Norma Complementar no 1/2011 - Serviço de Radiodifusão Comunitária.

Anexo - Norma Complementar no 1/2011 - Serviço de Radiodifusão Comunitária

Portaria MC no 69, de 17 de março de 2011 - Altera o Regimento Interno do Ministério das Comunicações aprovado pela Portaria $n^{\circ} 401$, de 22 de agosto de 2006.

Portaria MC no 498, de 5 de dezembro de 2011 - Aprova a Norma de Procedimentos de Autorização para a Execução do Serviço de Retransmissão de Televisão e do Serviço de Repetição de Televisão, ancilares ao Serviço de Radiodifusão de Sons e Imagens 
Anexo - Norma de Procedimentos de Autorização para a Execução do Serviço de Retransmissão de Televisão e do Serviço de Repetição de Televisão

Portaria MC no 561, de 22 de dezembro de 2011 - Altera a Norma de Procedimentos de Autorização para a Execução do Serviço de Retransmissão de Televisão e do Serviço de Repetição de Televisão, aprovada pela Portaria $\mathrm{n}^{\circ} 498$, de 5 de dezembro de 2011.

Atos

Portaria do Ministério das Comunicações n⿳ 69/2011 - Altera o Regimento Interno do Ministério das Comunicações aprovado pela Portaria $\mathrm{n}^{\circ} 401$, de 22 de agosto de 2006.

\section{Prestadora / Operadora}

\section{Normatização}

Decreto $\mathbf{n}^{\circ}$ 7.628, de 30 de novembro de 2011 - Aprova o Programa de Dispêndios Globais - PDG para 2012 das empresas estatais federais, e dá outras providências.

Resolução da ANATEL n $^{\circ}$ 567, de 24 de maio de 2011 - Aprova alteração do Regulamento do Serviço Telefônico Fixo Comutado, aprovado pela Resolução n 426, de 2005; do Regulamento do Serviço Móvel Pessoal, aprovado pela Resolução n 477, de 2007; e do Regulamento de Proteção e Defesa dos Direitos dos Assinantes dos Serviços de Televisão por Assinatura, aprovado pela Resolução no 488, de 2007, e alterado pela Resolução no 528, de 2009. Anexo - Alteração do Regulamento do Serviço Telefônico Fixo Comutado

Resolução da ANATEL $n^{\circ}$ 569, de 5 de agosto de 2011 - Aprova a prorrogação dos prazos estabelecidos nos arts. 12, 17 e 18 do Regulamento de Acompanhamento e Controle das Obrigações de Universalização do Serviço Telefônico Fixo Comutado destinado ao uso do público geral - STFC, aprovado pela Resolução n ${ }^{\circ}$ 536, de 9 de novembro de 2009, para o ano de 2011, e a alteração do referido regulamento, para incluir novo dispositivo (art. 23).

Resolução da ANATEL no 573, de 10 de outubro de 2011 - Aprova a Norma para Implantação e Acompanhamento de Liberdade Tarifária no Serviço Telefônico Fixo Comutado Destinado ao Uso Público em Geral, Modalidade Longa Distância Internacional.

\section{Atos}

Ato do Conselho Diretor da ANATEL no 1.970, de $1^{\circ}$ de abril de 2011 Anuência prévia à reestruturação societária decorrente da aquisição da Vivo pela Telefônica.

\section{Anexo}


Ato da Superintendência de Radiofrequencia e Fiscalização e da Superintendência de Serviços Públicos da ANATEL no 162, de 6 de janeiro de 2011 - Determinação à Empresa Brasileira de Telecomunicações S.A. para que efetue inventário físico do seu patrimônio, bem como a Relação de Bens Reversíveis consistente com o Inventário atualizado do seu patrimônio.

Ato da Superintendência de Radiofrequencia e Fiscalização e da Superintendência de Serviços Públicos da ANATEL no 160, de 6 de janeiro de 2011 - Determinação à Brasil Telecom para que efetue inventário físico do seu patrimônio, bem como Relação de Bens Reversíveis consistente com o Inventário atualizado do seu patrimônio

Ato do Conselho Diretor da ANATEL no 5.703, de 16 de agosto de 2011 Anuência prévia à incorporação da VIVO TELECOMUNICAÇÕES S/A pela TELECOMUNICAÇÕES DE SÃO PAULO S/A - TELESP.

Ato da Superintendência de Radiofrequencia e Fiscalização e da Superintendência de Serviços Públicos da ANATEL n 161, de 6 de janeiro de 2011 - Determinação à Telemar Note Leste S.A. para que efetue inventário físico do seu patrimônio, bem como a Relação de Bens Reversíveis consistente com o Inventário atualizado do seu patrimônio.

\section{Usuário / Consumidor}

\section{Normatização}

Resolução da ANATEL no 567, de 24 de maio de 2011 - Aprova alteração do Regulamento do Serviço Telefônico Fixo Comutado, aprovado pela Resolução n 426, de 2005; do Regulamento do Serviço Móvel Pessoal, aprovado pela Resolução no 477, de 2007; e do Regulamento de Proteção e Defesa dos Direitos dos Assinantes dos Serviços de Televisão por Assinatura, aprovado pela Resolução $n^{\circ} 488$, de 2007, e alterado pela Resolução no 528, de 2009.

Anexo - Alteração do Regulamento do Serviço Telefônico Fixo Comutado

Resolução da ANATEL no 569, de 5 de agosto de 2011 - Aprova a prorrogação dos prazos estabelecidos nos arts. 12, 17 e 18 do Regulamento de Acompanhamento e Controle das Obrigações de Universalização do Serviço Telefônico Fixo Comutado destinado ao uso do público geral - STFC, aprovado pela Resolução no 536, de 9 de novembro de 2009, para o ano de 2011, e a alteração do referido regulamento, para incluir novo dispositivo (art. 23).

Resolução da ANATEL no 573, de 10 de outubro de 2011 - Aprova a Norma para Implantação e Acompanhamento de Liberdade Tarifária no Serviço Telefônico Fixo Comutado Destinado ao Uso Público em Geral, Modalidade Longa Distância Internacional. 


\section{ANCINE}

\section{Normatização}

Lei $\mathbf{n}^{\circ}$ 12.485, de 12 de setembro de 2011 - Dispõe sobre a comunicação audiovisual de acesso condicionado; altera a Medida Provisória no 2.228-1, de 6 de setembro de 2001, e as Leis $n^{\circ}$ s 11.437 , de 28 de dezembro de 2006, 5.070, de 7 de julho de 1966, 8.977, de 6 de janeiro de 1995, e 9.472, de 16 de julho de 1997; e dá outras providências.

Anexo - Anexo I da Medida Provisória no 2.228-1, de 6 de setembro de 2001.

Previsão legal de competência da Ancine para regulação e fiscalização das atividades de programação e empacotamento na comunicação audiovisual de acesso condicionado.

\section{Normas Referenciadas}

\section{Lei Ordinária}

Lei $\mathbf{n}^{\mathbf{0}}$ 12.431, de 24 de junho de 2011 - Dispõe sobre a incidência do imposto sobre a renda nas operações que especifica; altera as Leis nos 11.478, de 29 de maio de 2007, 6.404, de 15 de dezembro de 1976, 9.430, de 27 de dezembro de 1996, 12.350, de 20 de dezembro de 2010, 11.196, de 21 de novembro de 2005, 8.248, de 23 de outubro de 1991, 9.648, de 27 de maio de 1998, 11.943, de 28 de maio de 2009, 9.808, de 20 de julho de 1999, 10.260, de 12 de julho de 2001, 11.096, de 13 de janeiro de $2005,11.180$, de 23 de setembro de 2005, 11.128, de 28 de junho de 2005, 11.909, de 4 de março de 2009, 11.371, de 28 de novembro de 2006, 12.249, de 11 de junho de 2010, 10.150, de 21 de dezembro de 2000, 10.312, de 27 de novembro de 2001, e 12.058, de 13 de outubro de 2009, e o Decreto-Lei no 288, de 28 de fevereiro de 1967; institui o Regime Especial de Incentivos para o Desenvolvimento de Usinas Nucleares (Renuclear); dispõe sobre medidas tributárias relacionadas ao Plano Nacional de Banda Larga; altera a legislação relativa à isenção do Adicional ao Frete para Renovação da Marinha Mercante (AFRMM); dispõe sobre a extinção do Fundo Nacional de Desenvolvimento; e dá outras providências.

\begin{tabular}{|c|c|}
\hline Dispositivos & 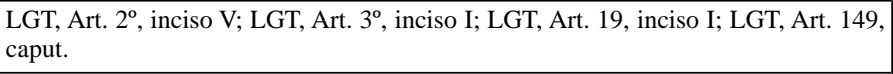 \\
\hline \multirow[t]{10}{*}{ Altera } & Lei ${ }^{\circ} 6.404 / 1976$ \\
\hline & Lei $\mathrm{n}^{\circ} 8.248 / 1991$ - Dispõe sobre a capacitação e competitividade do setor de \\
\hline & informática e automação, e dá outras providências. \\
\hline & Lei ${ }^{\circ}$ 9.430/1996 \\
\hline & Lei $n^{\circ} 10.260$, de 12 de julho de 2001 \\
\hline & Lei $n^{\circ} 10.312$, de 27 de novembro de 2001 \\
\hline & $\begin{array}{l}\text { Lei no } 11.196 / 2005 \text { - Institui o Regime Especial de Tributação para a Plataforma de } \\
\text { Exportação de Serviços de Tecnologia da Informação - REPES, o Regime Especial } \\
\text { de Aquisição de Bens de Capital para Empresas Exportadoras - RECAP e o Programa } \\
\text { de Inclusão Digital, dentre outras providências. }\end{array}$ \\
\hline & Lei 11.478 , de 29 de maio de 2007 \\
\hline & Lei 12.058 , de 13 de outubro de 2009 \\
\hline & $\begin{array}{l}\text { Lei } \mathrm{n}^{\circ} 12.350 / 2010 \text { - Dispõe sobre medidas tributárias referentes à realização, no } \\
\text { Brasil, da Copa das Confederações Fifa } 2013 \text { e da Copa do Mundo Fifa 2014; promove } \\
\text { desoneração tributária de subvenções governamentais destinadas ao fomento das }\end{array}$ \\
\hline
\end{tabular}




\begin{tabular}{|c|c|}
\hline & $\begin{array}{l}\text { atividades de pesquisa tecnológica e desenvolvimento de inovação tecnológica nas } \\
\text { empresas; altera as Leis nos } 11.774 \text {, de } 17 \text { de setembro de } 2008,10.182 \text {, de } 12 \text { de } \\
\text { fevereiro de } 2001,9.430 \text {, de } 27 \text { de dezembro de } 1996,7.713 \text {, de } 22 \text { de dezembro de } \\
1988,9.959 \text {, de } 27 \text { de janeiro de } 2000,10.887 \text {, de } 18 \text { de junho de } 2004,12.058 \text {, de } 13 \\
\text { de outubro de } 2009,10.865 \text {, de } 30 \text { de abril de } 2004,10.931 \text {, de } 2 \text { de agosto de } 2004 \text {, } \\
12.024 \text {, de } 27 \text { de agosto de } 2009,9.504 \text {, de } 30 \text { de setembro de } 1997,10.996 \text {, de } 15 \text { de } \\
\text { dezembro de } 2004,11.977 \text {, de } 7 \text { de julho de } 2009 \text {, e } 12.249 \text {, de } 11 \text { de junho de } 2010 \text {, } \\
\text { os Decretos-Leis nos } 37 \text {, de } 18 \text { de novembro de } 1966 \text {, e } 1.455 \text {, de } 7 \text { de abril de } 1976 \text {; } \\
\text { revoga dispositivos das Leis nos } 11.196 \text {, de } 21 \text { de novembro de } 2005,8.630 \text {, de } 25 \text { de } \\
\text { fevereiro de } 1993,9.718 \text {, de } 27 \text { de novembro de } 1998 \text {, e } 10.833 \text {, de } 29 \text { de dezembro } \\
\text { de } 2003 \text {; e dá outras providências. }\end{array}$ \\
\hline & $\begin{array}{l}\text { Decreto-Lei no } 288 / 1967 \text { - Altera as disposições da Lei número } 3.173 \text { de } 6 \text { de junho } \\
\text { de } 1957 \text { e regula a Zona Franca de Manaus. }\end{array}$ \\
\hline Publicação & \begin{tabular}{|l} 
Diário Oficial da União, Seção 1, 26/06/2011 \\
Diário Oficial da União, Seção 1, 29/06/2011 [ Retificação ]
\end{tabular} \\
\hline
\end{tabular}

Lei $\mathbf{n}^{\mathbf{0}}$ 12.485, de 12 de setembro de 2011 - Dispõe sobre a comunicação audiovisual de acesso condicionado; altera a Medida Provisória no 2.228-1, de 6 de setembro de 2001, e as Leis $\mathrm{n}^{\circ} \mathrm{s}$ 11.437, de 28 de dezembro de 2006, 5.070, de 7 de julho de 1966, 8.977, de 6 de janeiro de 1995, e 9.472, de 16 de julho de 1997; e dá outras providências.

\begin{tabular}{|c|c|}
\hline Anexos & Anexo - Anexo I da Medida Provisória n 2.228-1, de 6 de setembro de 2001. \\
\hline Dispositivos & $\begin{array}{l}\text { CF, Art. 21, inciso XI; CF, Art. 21, inciso XVI; CF, Art. 22, inciso IV; CF, Art. 48, } \\
\text { inciso XII; CF, Art. 170, inciso III; CF, Art. 220, § 5; CF, Art. 221, inciso IV; CF, } \\
\text { Art. 222, § } 3^{\circ} \text {; LGT, Art. } 1^{\circ} \text {, caput; LGT, Art. 86, caput; LGT, Art. 86, caput (em } \\
\text { 12/09/2011); LGT, Art. 212, caput. }\end{array}$ \\
\hline Altera & $\begin{array}{l}\text { Lei n }{ }^{\circ} 8.977 / 1995 \text { - Dispõe sobre o Serviço de TV a Cabo, e dá outras providências. } \\
\text { Lei no } \text { n }^{\circ} .472 / 1997 \text { - Dispõe sobre a organização dos serviços de telecomunicações, a } \\
\text { criação e funcionamento de um órgão regulador e outros aspectos institucionais, nos } \\
\text { termos da Emenda Constitucional n }{ }^{\circ} 8 \text {, de } 1995 \text {. } \\
\text { Medida Provisória n }{ }^{\circ} \text { 2.228-1/2001 }\end{array}$ \\
\hline Correlata & 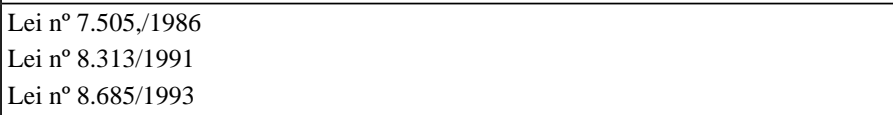 \\
\hline Regulamenta & Constituição da República Federativa do Brasil de 1988 \\
\hline Publicação & Diário Oficial da União, Seção 1, 13/09/2011 \\
\hline
\end{tabular}

Lei $\mathbf{n}^{\mathbf{0}}$ 12.507, de 11 de outubro de 2011 - Altera o art. 28 da Lei $\mathrm{n}^{\circ} 11.196$, de 21 de novembro de 2005, para incluir no Programa de Inclusão Digital tablet PC produzido no País conforme processo produtivo básico estabelecido pelo Poder Executivo; altera as Leis $\mathrm{n}^{\circ} 10.833$, de 29 de dezembro de $2003, \mathrm{n}^{\circ} 11.482$, de 31 de maio de 2007, $\mathrm{n}^{\circ} 11.508$, de 20 de julho de 2007, e ${ }^{\circ} 8.212$, de 24 de julho de 1991; e revoga dispositivo da Medida Provisória n ${ }^{\circ}$ 540, de 2 de agosto de 2011.

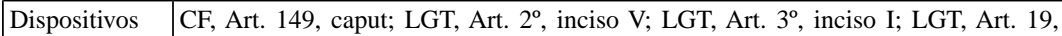
inciso I.

\begin{tabular}{|l|l|}
\hline Altera & Lei no $^{\circ} 8.212$, de 24 de julho de 1991
\end{tabular}

Lei $\mathrm{n}^{\circ} 10.833 / 2003$

Lei no 11.196/2005 - Institui o Regime Especial de Tributação para a Plataforma de Exportação de Serviços de Tecnologia da Informação - REPES, o Regime Especial 


\begin{tabular}{|l|l|}
\hline & $\begin{array}{l}\text { de Aquisição de Bens de Capital para Empresas Exportadoras - RECAP e o Programa } \\
\text { de Inclusão Digital, dentre outras providências. } \\
\text { Lei } n^{\circ} 11.482, \text { de } 31 \text { de maio de } 2007 \\
\text { Lei } n^{\circ} 11.508, \text { de } 20 \text { de julho de } 2007 \\
\text { Medida Provisória }{ }^{\circ} \text { 540, de } 2 \text { de agosto de } 2011\end{array}$ \\
\hline Publicação & Diário Oficial da União, Seção $1,13 / 10 / 2011$ \\
\hline
\end{tabular}

Lei $\mathbf{n}^{0}$ 12.527, de 18 de novembro de 2011 - Regula o acesso a informações previsto no inciso XXXIII do art. $5^{\circ}$, no inciso II do $\S 3^{\circ}$ do art. 37 e no $\S 2^{\circ}$ do art. 216 da Constituição Federal; altera a Lei $n^{\circ}$ 8.112, de 11 de dezembro de 1990; revoga a Lei ${ }^{\circ} 11.111$, de 5 de maio de 2005, e dispositivos da Lei $\mathrm{n}^{\circ} 8.159$, de 8 de janeiro de 1991 ; e dá outras providências.

\begin{tabular}{|l|l|}
\hline Dispositivos & CF, Art. 37; LGT, Art. 39, caput; LGT, Art. 174, caput. \\
\hline Altera & $\begin{array}{l}\text { Lei } \text { n }^{\circ} 8.112 / 1990 \text { - Dispõe sobre o regime jurídico dos servidores públicos civis da } \\
\text { União, das autarquias e das fundações públicas federais. } \\
\text { Lei no } 8.159 / 1991 \text { - Dispõe sobre a política nacional de arquivos públicos e privados } \\
\text { e dá outras providências. }\end{array}$ \\
\hline Correlata & Lei 9.507, de 12 de novembro de 1997 \\
\hline Regulamenta & Constituição da República Federativa do Brasil de 1988 \\
\hline Publicação & Diário Oficial da União, Edição Extra, 18/11/2001, págs. 1-4 \\
\hline
\end{tabular}

Lei no 12.529, de 30 de novembro de 2011 - Estrutura o Sistema Brasileiro de Defesa da Concorrência; dispõe sobre a prevenção e repressão às infrações contra a ordem econômica; altera a Lei no ${ }^{\circ} .137$, de 27 de dezembro de 1990, o Decreto-Lei n 3.689 , de 3 de outubro de 1941 - Código de Processo Penal, e a Lei $n^{\circ} 7.347$, de 24 de julho de 1985; revoga dispositivos da Lei $n^{\circ} 8.884$, de 11 de junho de 1994, e a Lei n 9.781, de 19 de janeiro de 1999; e dá outras providências.

\begin{tabular}{|c|c|}
\hline Dispositivos & $\begin{array}{l}\text { CF, Art. 170, inciso IV; CF, Art. 173, } \S 4^{\circ} \text { (em 04/06/1998); LGT, Art. } 7^{\circ}, \S 2^{\circ} \text {; LGT, } \\
\text { Art. 19, inciso XIX; LGT, Art. 70, caput. }\end{array}$ \\
\hline Altera & $\begin{array}{l}\text { Lei no } 7.347 / 1985 \\
\text { Lei n }{ }^{\circ} 8.137 / 1990 \\
\text { Lei no }{ }^{\circ} 8.884 / 1994 \text { - Transforma o Conselho Administrativo de Defesa Econômica } \\
\text { (Cade) em Autarquia, dispõe sobre a prevenção e a repressão às infrações contra a } \\
\text { ordem econômica e dá outras providências. } \\
\text { Código de Processo Penal }\end{array}$ \\
\hline Correlata & $\begin{array}{l}\text { Lei } 8.437, \text { de } 30 \text { de junho de } 1992 \\
\text { Lei } n^{\circ} 5.869 / 1973 \\
\text { Lei } n^{\circ} 6.404 / 1976 \\
\text { Lei } 6.830 \text {, de } 22 \text { de setembro de } 1980 \\
\text { Lei no } 7.347 / 1985 \\
\text { Lei n }{ }^{\circ} 8.078 / 1990 \text { - Código de Defesa do Consumidor. } \\
\text { Lei 9.008, de } 21 \text { de março de } 1995 \\
\text { Lei } n^{\circ} 9.784 / 1999 \text { - Regula o processo administrativo no âmbito da Administração } \\
\text { Pública Federal. }\end{array}$ \\
\hline Regulamenta & Constituição da República Federativa do Brasil de 1988 \\
\hline Publicação & Diário Oficial da União, Seção 1, 01/01/2011 \\
\hline
\end{tabular}




\section{Decreto}

Decreto no 7.512, de 30 de junho de 2011 - Aprova o Plano Geral de Metas para a Universalização do Serviço Telefônico Fixo Comutado Prestado no Regime Público - PGMU, e dá outras providências.

\begin{tabular}{|l|l|}
\hline Anexos & Anexo 1 - Anexo 1 ao Decreto ${ }^{\circ}$ 7.512, de 30 de junho de 2011 - Plano Geral de
\end{tabular} Metas para a Universalização do Serviço Telefônico Fixo Comutado Prestado no Regime Público - PGMU

Anexo 2 - Telefones de Uso Público - Concessionárias do STFC na Modalidade Local Anexo 3 - Telefones de Uso Público - Concessionária do STFC nas Modalidades Longa Distância Nacional e Internacional

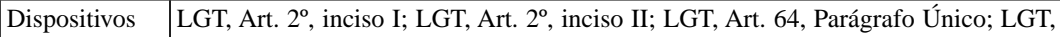
Art. 79, § $1^{\circ}$; LGT, Art. 80, caput.

\begin{tabular}{l|l} 
Regulamenta & Lei ${ }^{\circ} 9.472 / 1997$ - Dispõe sobre a organização dos serviços de telecomunicações, a
\end{tabular} criação e funcionamento de um órgão regulador e outros aspectos institucionais, nos termos da Emenda Constitucional no 8, de 1995.

Publicação $\quad$ Diário Oficial da União, Edição Extra, 30/06/2011

Diário Oficial da União, Seção 1, 07/07/2011 [ Retificação ]

Decreto $n^{0}$ 7.628, de 30 de novembro de 2011 - Aprova o Programa de Dispêndios Globais - PDG para 2012 das empresas estatais federais, e dá outras providências.

\begin{tabular}{|l|l|}
\hline Anexos & \\
\hline Dispositivos & LGT, Art. 186, caput. \\
\hline
\end{tabular}

\section{Portaria Ministerial}

Portaria MC n⿳ 256, de 6 de julho de 2011 - Dispõe sobre a análise de pedido de outorga para a execução dos serviços de radiodifusão sonora e de sons e imagens, com fins exclusivamente educativos.

\begin{tabular}{|c|c|}
\hline Órgão Emissor & Ministério das Comunicações - Gabinete do Ministro. \\
\hline Dispositivos & CF, Art. $223, \S 3^{\circ}$; LGT, Art. 211 , caput. \\
\hline \multirow[t]{3}{*}{ Correlata } & $\begin{array}{l}\text { Decreto-Lei }{ }^{\circ} \text { 236/1967 - Complementa e modifica a Lei número } 4.117 \text { de } 27 \text { de } \\
\text { agôsto de } 1962 .\end{array}$ \\
\hline & $\begin{array}{l}\text { Anexo ao Decreto n }{ }^{\circ} 52.795 \text {, de } 31 \text { de outubro de } 1963 \text { - Regulamento dos Serviços } \\
\text { de Radiodifusão. }\end{array}$ \\
\hline & $\begin{array}{l}\text { Decreto } \mathrm{n}^{\circ} 2.108 / 1996 \text { - Altera dispositivos do Regulamento dos Serviços de } \\
\text { Radiodifusão, aprovado pelo Decreto } \mathrm{n}^{\circ} 52.795 \text {, de } 31 \text { de outubro de } 1963 \text {, e } \\
\text { modificado por disposições posteriores. }\end{array}$ \\
\hline Regulamenta & Lei nº 4.117/1962 - Institui o Código Brasileiro de Telecomunicações. \\
\hline $\mathrm{bbl}$ & /201 \\
\hline
\end{tabular}

Portaria MC no 376, de 19 de agosto de 2011 - Institui o Projeto de Implantação e Manutenção das Cidades Digitais.

Órgão Emissor Ministério das Comunicações - Gabinete do Ministro.

\begin{tabular}{l|l}
\hline Dispositivos & LGT, Art. $2^{\circ}$, inciso I.
\end{tabular}


\begin{tabular}{|l|l}
\hline Publicação & Diário Oficial da União, Seção 1, 22/08/2011, pág. 76 \\
\hline
\end{tabular}

Portaria MC no 420, de 14 de setembro de 2011 - Dispõe sobre o procedimento para outorga dos serviços de radiodifusão sonora e de sons e imagens, com fins exclusivamente educativos.

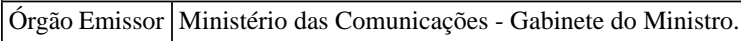

\begin{tabular}{|l|l|}
\hline Anexos & Anexo - Documentos necessários à instrução das propostas das pessoas jurídicas de
\end{tabular} direito público interno, em original ou cópia autenticada.

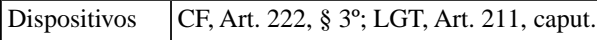

\begin{tabular}{l|l} 
Correlata & Decreto-Lei $\mathrm{n}^{\circ}$ 236/1967 - Complementa e modifica a Lei número 4.117 de 27 de
\end{tabular} agôsto de 1962.

Decreto $\mathrm{n}^{\circ}$ 52.795/1963 - Aprova o Regulamento dos Serviços de Radiodifusão.

Decreto $\mathrm{n}^{\circ}$ 2.108/1996 - Altera dispositivos do Regulamento dos Serviços de Radiodifusão, aprovado pelo Decreto $\mathrm{n}^{\circ}$ 52.795, de 31 de outubro de 1963, e modificado por disposições posteriores.

\begin{tabular}{l|l} 
Regulamenta & Lei n $^{\circ}$ 4.117/1962 - Institui o Código Brasileiro de Telecomunicações.
\end{tabular}

\begin{tabular}{l|l} 
Publicação & Diário Oficial da União, Seção 1, 19/09/2011, págs. 67-69 \\
\hline
\end{tabular}

Resolução $n^{\circ}$ 4, de 16 de setembro de 2011 - Reafirma o entendimento do CGI.br sobre a natureza do serviço de conexão à internet.

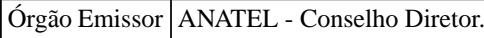

\begin{tabular}{l|l}
\hline Dispositivos & LGT, Art. 61, $\S 2^{\circ}$.
\end{tabular}

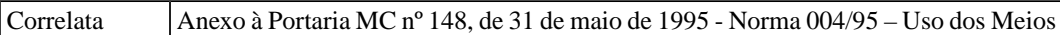
da Rede Pública de Telecomunicações para Acesso à INTERNET.

\begin{tabular}{|c|c|}
\hline rta & $\begin{array}{l}\text { 2, de } 14 \text { de outubro de } 2011 \text { - Aprova a Norma Complementar no } 1 / 2011 \text { - Se } \\
\text { omunitária. }\end{array}$ \\
\hline Órgão Emissor & Ministério das Comunicações - Gabinete do Ministro. \\
\hline Anexos & Anexo - Norma Complementar nº 1/2011 - Serviço de Radiodifusão Comunitária \\
\hline Dispositivos & CF, Art. 21, inciso XII, alínea a; LGT, Art. 211, caput. \\
\hline Correlata & $\begin{array}{l}\text { Lei no 4.117/1962 - Institui o Código Brasileiro de Telecomunicações. } \\
\text { Lei no 9.612/1998 - Institui o Serviço de Radiodifusão Comunitária e dá outras } \\
\text { providências. } \\
\text { Medida Provisória no 2.216-37/2001 } \\
\text { Decreto no 52.795/1963 - Aprova o Regulamento dos Serviços de Radiodifusão. } \\
\text { Resolução da ANATEL no 60/1998 - Designação de canal para utilização no Serviço } \\
\text { de Radiodifusão Comunitária. } \\
\text { Resolução da ANATEL no } 67 / 1998 \text { - Aprova o Regulamento Técnico para Emissoras } \\
\text { de Radiodifusão Sonora em Freqüência Modulada. }\end{array}$ \\
\hline Regulamenta & $\begin{array}{l}\text { Decreto } \mathrm{n}^{\circ} \text { 2.615/1998 - Aprova o Regulamento do Serviço de Radiodifusão } \\
\text { Comunitária. }\end{array}$ \\
\hline $\mathrm{ubl}$ & $3 / 10 / 2011$ \\
\hline
\end{tabular}

Portaria MC n ${ }^{0}$ 69, de 17 de março de 2011 - Altera o Regimento Interno do Ministério das Comunicações aprovado pela Portaria $\mathrm{n}^{\circ} 401$, de 22 de agosto de 2006. 


\begin{tabular}{|l|l|}
\hline Órgão Emissor & Ministério das Comunicações - Gabinete do Ministro. \\
\hline Dispositivos & LGT, Art. $1^{\circ}$, Parágrafo Único; LGT, Art. 211, Parágrafo Único. \\
\hline Altera & $\begin{array}{l}\text { Portaria MC } \mathrm{n}^{\circ} \text { 401/2006 - Aprova o Regimento Interno do Ministério das } \\
\text { Comunicações }\end{array}$ \\
\hline Publicação & Diário Oficial da União, Seção 1, 18/03/2011, pág. 71 \\
\hline
\end{tabular}

Portaria MC n ${ }^{\circ}$ 491, de 23 de novembro de 2011 - Altera a Portaria $n^{\circ}$ 652, de 10 de outubro de 2006.

Órgão Emissor Ministério das Comunicações - Gabinete do Ministro.

\begin{tabular}{|l|l|}
\hline Dispositivos & LGT, Art. 211, caput. \\
\hline Altera & $\begin{array}{l}\text { Portaria MC } \mathrm{n}^{\circ} \text { 652/2006 - Estabelece critérios, procedimentos e prazos para a } \\
\text { consignação de canais de radiofreqüência destinados à transmissão digital do serviço } \\
\text { de radiodifusão de sons e imagens do serviço de retransmissão de televisão, no âmbito } \\
\text { do Sistema Brasileiro de Televisão Digital Terrestre - SBTVD-T. }\end{array}$ \\
\hline Correlata & $\begin{array}{l}\text { Decreto-Lei } \mathrm{n}^{\circ} \text { 236/1967 - Complementa e modifica a Lei número } 4.117 \text { de } 27 \text { de } \\
\text { agôsto de 1962. }\end{array}$ \\
\hline Publicação & Diário Oficial da União, Seção 1,24/11/2011, págs. 96-97 \\
\hline
\end{tabular}

Portaria MC n⿳0 498, de 5 de dezembro de 2011 - Aprova a Norma de Procedimentos de Autorização para a Execução do Serviço de Retransmissão de Televisão e do Serviço de Repetição de Televisão, ancilares ao Serviço de Radiodifusão de Sons e Imagens

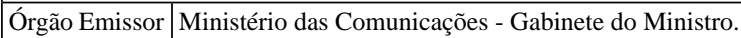

\begin{tabular}{|l|l|}
\hline Anexos & Anexo - Norma de Procedimentos de Autorização para a Execução do Serviço de
\end{tabular} Retransmissão de Televisão e do Serviço de Repetição de Televisão

\begin{tabular}{l|l} 
Dispositivos & LGT, Art. 211, caput. \\
\hline
\end{tabular}

\begin{tabular}{l|l} 
Correlata & Decreto $\mathrm{n}^{\circ}$ 5.371/2005 - Aprova o Regulamento do Serviço de Retransmissão de
\end{tabular} Televisão e do Serviço de Repetição de Televisão, ancilares ao Serviço de Radiodifusão de Sons e Imagens. - Anexo - Regulamento do Serviço de Retransmissão de Televisão e do Serviço de Repetição de Televisão, ancilares ao Serviço de Radiodifusão de Sons e Imagens.

Decreto $n^{\circ}$ 5.820/2006 - Dispõe sobre a implantação do SBTVD-T, estabelece diretrizes para a transição do sistema de transmissão analógica para o sistema de transmissão digital do serviço de radiodifusão de sons e imagens e do serviço de retransmissão de televisão, e dá outras providências.

Portaria $\mathrm{MC} \mathrm{n}^{\circ}$ 93/1989

Portaria MC $\mathrm{n}^{\circ} 652 / 2006$ - Estabelece critérios, procedimentos e prazos para a consignação de canais de radiofrequiência destinados à transmissão digital do serviço de radiodifusão de sons e imagens do serviço de retransmissão de televisão, no âmbito do Sistema Brasileiro de Televisão Digital Terrestre - SBTVD-T.

Portaria MC n 276/2010 - Aprova a Norma $n^{\circ}$ 01/2010 - Norma Técnica para Execução dos Serviços de Radiodifusão de Sons e Imagens e de Retransmissão de Televisão com utilização da tecnologia digital. - Anexo - Norma Técnica para Execução dos Serviços de Radiodifusão de Sons e Imagens e de Retransmissão de Televisão com utilização da tecnologia digital.

Resolução da ANATEL n 284/2001 - Aprova o Regulamento Técnico para a Prestação do Serviço de Radiodifusão de Sons e Imagens e do Serviço de Retransmissão de 


\begin{tabular}{|l|l|}
\hline & $\begin{array}{l}\text { Televisão. - Anexo - Regulamento Técnico para a Prestação do Serviço de Radiodifusão } \\
\text { de Sons e Imagens e do Serviço de Retransmissão de Televisão. }\end{array}$ \\
\hline Publicação & Diário Oficial da União, Seção 1, 06/12/2011, págs. 45-47 \\
\hline
\end{tabular}

Portaria MC n ${ }^{0}$ 561, de 22 de dezembro de 2011 - Altera a Norma de Procedimentos de Autorização para a Execução do Serviço de Retransmissão de Televisão e do Serviço de Repetição de Televisão, aprovada pela Portaria n ${ }^{\circ} 498$, de 5 de dezembro de 2011.

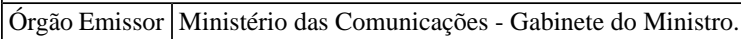

$\begin{array}{ll}\text { Dispositivos } & \text { LGT, Art. 211, caput. }\end{array}$

\begin{tabular}{|l|l}
\hline Publicação & Diário Oficial da União, Seção 1, 26/12/2011, pág. 264
\end{tabular}

\section{Resolução}

Resolução da ANATEL no 560, de 21 de janeiro de 2011 - Aprova o Regulamento sobre Áreas Locais para o Serviço Telefônico Fixo Comutado Destinado ao Uso do Público em Geral - STFC.

\begin{tabular}{|c|c|}
\hline Órgão Emissor & ANATEL - Conselho Diretor. \\
\hline Anexos & $\begin{array}{l}\text { Anexo - Regulamento sobre Áreas Locais para o Serviço Telefônico Fixo Comutado } \\
\text { Destinado ao Uso do Público em Geral - STFC. }\end{array}$ \\
\hline Dispositivos & $\begin{array}{l}\text { LGT, Art. } 2^{\circ} \text {, inciso I; LGT, Art. } 2^{\circ} \text {, inciso II; LGT, Art. 64, Parágrafo Único; LGT, } \\
\text { Art. 214, inciso I. }\end{array}$ \\
\hline Revoga & 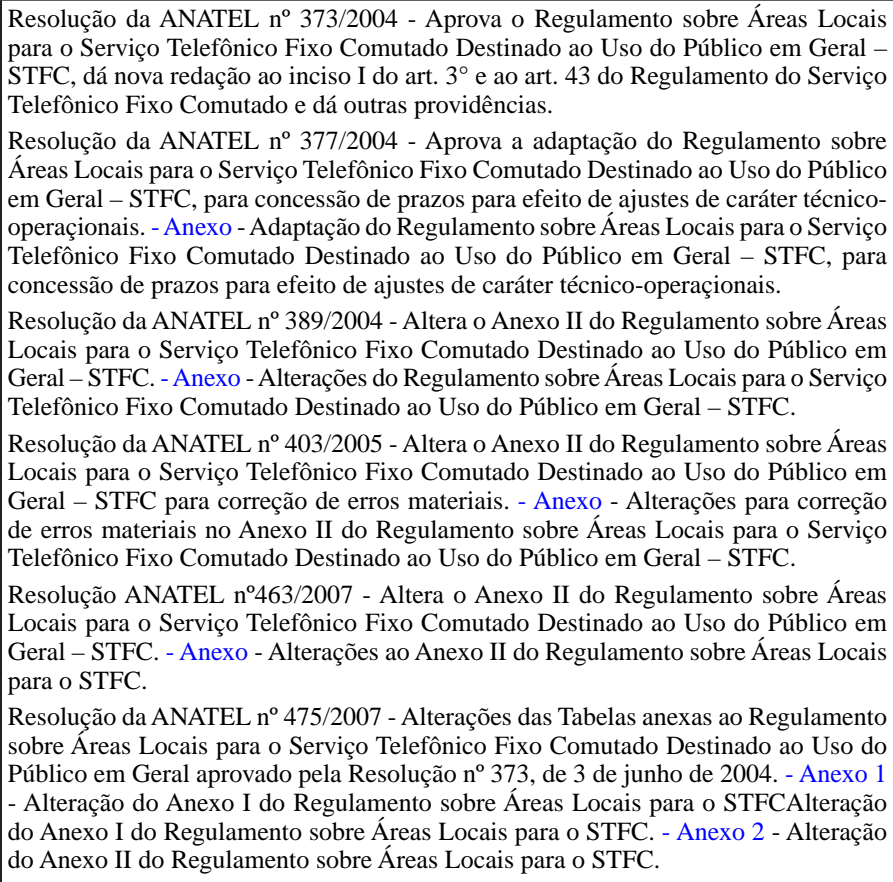 \\
\hline
\end{tabular}




\begin{tabular}{|c|c|}
\hline & $\begin{array}{l}\text { Resolução da ANATEL no 499/2008 - Altera os Anexos I e II do Regulamento sobre } \\
\text { Áreas Locais para o Serviço Telefônico Fixo Comutado Destinado ao Uso do Público } \\
\text { em Geral - STFC. - Anexo } 1 \text { - Altera o Anexo I do Regulamento sobre Áreas Locais. } \\
\text { - Anexo } 2 \text { - Altera o Anexo II do Regulamento sobre Âreas Locais. } \\
\text { Resolução da ANATEL no } 534 / 2009 \text { - Altera os Anexos I e II do Regulamento sobre } \\
\text { Áreas Locais para o Serviço Telefônico Fixo Comutado Destinado ao Uso do Público } \\
\text { em Geral - STFC. - Anexo } 1 \text { - Do Regulamento sobre Áreas Locais para o STFC. - } \\
\text { Anexo } 2 \text { - Regulamento sobre Áreas Locais para o STFC. }\end{array}$ \\
\hline Correlata & $\begin{array}{l}\text { Decreto } \mathrm{n}^{\circ} \text { 6.654/2008 - Aprova o Plano Geral de Outorgas de Serviço de } \\
\text { Telecomunicações prestado no regime público. - Anexo } 1 \text { - Plano Geral de Outorgas. } \\
\text { - Anexo } 2 \text { - Regiões do Plano Geral de Outorgas. - Anexo } 3 \text { - Setores das Regiões do } \\
\text { Plano Geral de Outorgas } \\
\text { Resolução da ANATEL } \mathrm{n}^{\circ} \text { 426/2005 - Aprova o Regulamento do Serviço Telefônico } \\
\text { Fixo Comutado - STFC. }\end{array}$ \\
\hline Regulamenta & $\begin{array}{l}\text { Lei no } 9.472 / 1997 \text { - Dispõe sobre a organização dos serviços de telecomunicações, a } \\
\text { criação e funcionamento de um órgão regulador e outros aspectos institucionais, nos } \\
\text { termos da Emenda Constitucional no } 8 \text {, de } 1995 \text {. }\end{array}$ \\
\hline Publicação & Diário Oficial da União, Seção 1, 27/01/2011, págs. 77-93 \\
\hline
\end{tabular}

Resolução da ANATEL $n^{0}$ 561, de 28 de janeiro de 2011 - Aprova Alteração do Regulamento sobre Condições de Uso de Radiofrequências nas Faixas de 25,35 GHz a 28,35 GHz, 29,10 GHz a 29,25 $\mathrm{GHz}$ e $31,00 \mathrm{GHz}$ a $31,30 \mathrm{GHz}$.

\begin{tabular}{|l|l|}
\hline Órgão Emissor & ANATEL - Conselho Diretor. \\
\hline Anexos & $\begin{array}{l}\text { - Alteração do Regulamento sobre Condições de Uso de Radiofrequências nas Faixas } \\
\text { de 25,35 GHz a 28,35 GHz, 29,10 GHz a 29,25 GHz e 31,00 GHz a 31,30 GHz. }\end{array}$ \\
\hline Dispositivos & LGT, Art. 19, inciso VIII; LGT, Art. 160, caput; LGT, Art. 161, caput. \\
\hline Regulamenta & $\begin{array}{l}\text { Lei no } 9.472 / 1997 \text { - Dispõe sobre a organização dos serviços de telecomunicações, a } \\
\text { criação e funcionamento de um órgão regulor e outros aspectos institucionais, nos } \\
\text { termos da Emenda Constitucional no 8, de 1995. }\end{array}$ \\
\hline Publicação & Diário Oficial da União, Seção 1, 03/02/2011, págs. 27-29 \\
\hline
\end{tabular}

Resolução da ANATEL $\mathbf{n}^{0}$ 562, de 9 de fevereiro de 2011 - Altera dispositivo do Regulamento anexo à Resolução ${ }^{\circ}$ 454, de 11 de dezembro de 2006, sobre Condições de Uso de Radiofrequiências nas Faixas de $800 \mathrm{MHz}, 900 \mathrm{MHz}, 1.800 \mathrm{MHz}, 1.900 \mathrm{MHz}$ e $2.100 \mathrm{MHz}$.

\begin{tabular}{|l|l|}
\hline Órgão Emissor & ANATEL - Conselho Diretor. \\
\hline Anexos & $\begin{array}{l}\text { Anexo - Altera dispositivo do Regulamento anexo à Resolução } \mathrm{n}^{\circ} \text { 454, de } 11 \mathrm{de} \\
\text { dezembro de 2006, sobre Condições de Uso de Radiofrequiências nas Faixas de } 800 \\
\mathrm{MHz}, 900 \mathrm{MHz}, 1.800 \mathrm{MHz}, 1.900 \mathrm{MHz} \text { e 2.100 MHz. }\end{array}$ \\
\hline Dispositivos & LGT, Art. 19, inciso VIII; LGT, Art. 157, caput; LGT, Art. 160, caput. \\
\hline Altera & $\begin{array}{l}\text { Anexo à Resolução da ANATEL no 454, de 11 de dezembro de } 2006 \text { - Regulamento } \\
\text { sobre Condições de Uso de Radiofreqüências nas Faixas de } 800 \mathrm{MHz}, 900 \mathrm{MHz}, \\
1.800 \mathrm{MHz}, 1.900 \mathrm{MHz} \text { e 2.100 MHz. }\end{array}$ \\
\hline Regulamenta & $\begin{array}{l}\text { Lei } \mathrm{n}^{\circ} \text { 9.472/1997 - Dispõe sobre a organização dos serviços de telecomunicações, a } \\
\text { criação e funcionamento de um órgão regulador e outros aspectos institucionais, nos } \\
\text { termos da Emenda Constitucional no }\end{array}$ \\
\hline
\end{tabular}


\begin{tabular}{|l|l}
\hline Publicação & Diário Oficial da União, Seção 1, 11/02/2011, págs. 52-53 \\
\hline
\end{tabular}

Resolução da ANATEL $\mathbf{n}^{\circ}$ 563, de 30 de março de 2011 - Alteração na Destinação das Faixas de Radiofrequências de $12,2 \mathrm{GHz}$ a $12,7 \mathrm{GHz}$ e de $17,3 \mathrm{GHz}$ a $17,7 \mathrm{GHz}$.

\begin{tabular}{l|l} 
Órgão Emissor & ANATEL - Conselho Diretor.
\end{tabular}

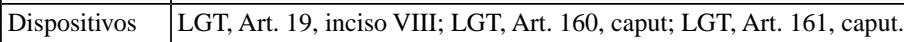

\begin{tabular}{l|l} 
Correlata & Resolução da ANATEL $n^{\circ}$ 516/2008 - Aprova o Plano Geral de Atualização da
\end{tabular} Regulamentação das Telecomunicações no Brasil (PGR).

Regulamenta $\quad$ Lei ${ }^{\circ}$ 9.472/1997 - Dispõe sobre a organização dos serviços de telecomunicações, a criação e funcionamento de um órgão regulador e outros aspectos institucionais, nos termos da Emenda Constitucional no 8 , de 1995.

Publicação $\quad$ Diário Oficial da União, Seção 1, 01/05/2011, pág. 66

Resolução da ANATEL $n^{0}$ 564, de 20 de abril de 2011 - Aprova alteração no Regulamento do Serviço Móvel Pessoal - SMP, aprovado pela Resolução n ${ }^{\circ} 477$, de 7 de agosto de 2007, e alterado pelas Resoluções no 491, de 12 de fevereiro de 2008, e n ${ }^{\circ}$ 509, de 14 de agosto de 2008.

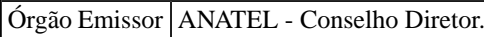

\begin{tabular}{|c|c|}
\hline Anexos & Anexo \\
\hline Dispositivos & LGT, Art. $3^{\circ}$, caput; LGT, Art. $6^{\circ}$, caput. \\
\hline Altera & $\begin{array}{l}\text { Anexo à Resolução da ANATEL n }{ }^{\circ} 477 \text {, de } 7 \text { de agosto de } 2007 \text { - Regulamento do } \\
\text { Serviço Móvel Pessoal - SMP. }\end{array}$ \\
\hline Regulamenta & $\begin{array}{l}\text { Lei } \text { n }^{\circ} 9.472 / 1997 \text { - Dispõe sobre a organização dos serviços de telecomunicações, a } \\
\text { criação e funcionamento de um órgão regulador e outros aspectos institucionais, nos } \\
\text { termos da Emenda Constitucional no } 8 \text {, de } 1995 \text {. }\end{array}$ \\
\hline Publicação & 26/01/2011, pág. 58 \\
\hline
\end{tabular}

Resolução da ANATEL $n^{0}$ 565, de 26 de abril de 2011 - Aprova a alteração dos Contratos de Concessão para a prestação do Serviço Telefônico Fixo Comutado - STFC, nas modalidades de serviço Local, Longa Distância Nacional - LDN e Longa Distância Internacional - LDI.

\begin{tabular}{l|l} 
Órgão Emissor & ANATEL - Conselho Diretor.
\end{tabular}

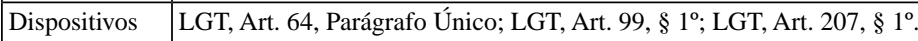

\begin{tabular}{|l|l|l}
\hline Altera & Anexo 1 à Resolução da ANATEL n ${ }^{\circ} 341$, de 20 de junho de 2003 - Modelo de \\
\hline
\end{tabular} Contrato de Concessão para a Prestação de Serviço Telefônico Fixo Comutado na Modalidade Local - 2006.

Anexo 2 à Resolução da ANATEL no 341, de 20 de junho de 2003 - Modelo de Contrato de Concessão para a Prestação de Serviço Telefônico Fixo Comutado na Modalidade Longa Distância Nacional - 2006 (somente Embratel).

Anexo 3 à Resolução da ANATEL nº 341, de 20 de junho de 2003 - Modelo de Contrato de Concessão para a Prestação de Serviço Telefônico Fixo Comutado na Modalidade Longa Distância Nacional - 2006 (exceto Embratel).

Anexo 4 à Resolução da ANATEL n 341, de 20 de junho de 2003 - Modelo de Contrato de Concessão para a Prestação de Serviço Telefônico Fixo Comutado na Modalidade Longa Distância Internacional - 2006.

Regulamenta $\quad$ Lei n 9.472/1997 - Dispõe sobre a organização dos serviços de telecomunicações, a criação e funcionamento de um órgão regulador e outros aspectos institucionais, nos termos da Emenda Constitucional no 8, de 1995. 
\begin{tabular}{|l|l}
\hline Publicação & Diário Oficial da União, Seção 1, 27/04/2011, pág. 80
\end{tabular}

Resolução da ANATEL n $^{0}$ 567, de 24 de maio de 2011 - Aprova alteração do Regulamento do Serviço Telefônico Fixo Comutado, aprovado pela Resolução no 426, de 2005; do Regulamento do Serviço Móvel Pessoal, aprovado pela Resolução no 477, de 2007; e do Regulamento de Proteção e Defesa dos Direitos dos Assinantes dos Serviços de Televisão por Assinatura, aprovado pela Resolução $n^{\circ} 488$, de 2007, e alterado pela Resolução nº 528, de 2009.

\begin{tabular}{|c|c|}
\hline Órgão Emissor & etor. \\
\hline Anexos & Anexo - Alteração do Regulamento do Serviço Telefônico Fixo Comutado \\
\hline Dispositivos & $\begin{array}{l}\text { CF, Art. } 5^{\circ} \text {, inciso XXXII; LGT, Art. } 3^{\circ} \text {, caput; LGT, Art. 127, caput; LGT, Art. 127, } \\
\text { inciso III. }\end{array}$ \\
\hline Altera & $\begin{array}{l}\text { Anexo à Resolução da ANATEL no 426, de } 9 \text { de dezembro de } 2005 \text { - Regulamento } \\
\text { do Serviço Telefônico Fixo Comutado. } \\
\text { Anexo à Resolução da ANATEL n }{ }^{\circ} 477 \text {, de } 7 \text { de agosto de } 2007 \text { - Regulamento do } \\
\text { Serviço Móvel Pessoal - SMP. } \\
\text { Anexo à Resolução da ANATEL no 488, de } 3 \text { de dezembro de } 2007 \text { - Regulamento } \\
\text { de Proteção e Defesa dos Direitos dos Assinantes dos Serviços de Televisão por } \\
\text { Assinatura. }\end{array}$ \\
\hline Correlata & $\begin{array}{l}\text { Lei } \mathrm{n}^{\circ} \text { 8.078/1990 - Código de Defesa do Consumidor. } \\
\text { Decreto n } 6.523 / 2008 \text { - Regulamenta a Lei no } 8.078 \text {, de } 11 \text { de setembro de 1990, para } \\
\text { fixar normas gerais sobre o Serviço de Atendimento ao Consumidor - SAC. } \\
\text { Portaria SDE } \mathrm{n}^{\circ} 49 / 2009 \text { - Para efeitos de harmonização dos procedimentos } \\
\text { administrativos para o cumprimento das normas do Decreto 6.523, de } 31 \text { de julho de } \\
\text { 2008, pelos órgãos públicos de defesa do consumidor, especifica hipótese prevista no } \\
\text { elenco de práticas abusivas constante do art. } 39 \text { da Lei n }{ }^{\circ} 8.078 \text {, de } 11 \text { de setembro } \\
\text { de } 1990 \text {, e dá outras providências. }\end{array}$ \\
\hline Regulamenta & $\begin{array}{l}\text { Lei no 9.472/1997 - Dispõe sobre a organização dos serviços de telecomunicações, a } \\
\text { criação e funcionamento de um órgão regulador e outros aspectos institucionais, nos } \\
\text { termos da Emenda Constitucional no } 8 \text {, de } 1995 \text {. }\end{array}$ \\
\hline $\mathrm{abl}$ & gs. $107-108$ \\
\hline
\end{tabular}

Resolução da ANATEL n ${ }^{0}$ 568, de 15 de junho de 2011 - Republica, com alterações, o Regulamento sobre Canalização e Condições de Uso de Radiofrequências na Faixa de 148 MHz a 174 MHz.

\begin{tabular}{|l|l|}
\hline Órgão Emissor & ANATEL - Conselho Diretor. \\
\hline Anexos & \\
\hline Dispositivos & LGT, Art. 19, inciso VIII. \\
\hline Regulamenta & $\begin{array}{l}\text { Lei }{ }^{\circ} \text { 9.472/1997 - Dispõe sobre a organização dos serviços de telecomunicações, a } \\
\text { criação e funcionamento de um órgão regulador e outros aspectos institucionais, nos } \\
\text { termos da Emenda Constitucional no } 8 \text {, de 1995. }\end{array}$ \\
\hline Publicação & Diário Oficial da União, Seção 1, 28/06/2011, págs. 38-43 \\
\hline
\end{tabular}

Resolução da ANATEL $\mathbf{n}^{\circ}$ 569, de 5 de agosto de 2011 - Aprova a prorrogação dos prazos estabelecidos nos arts. 12, 17 e 18 do Regulamento de Acompanhamento e Controle das Obrigações de Universalização do Serviço Telefônico Fixo Comutado destinado ao uso do público geral - STFC, aprovado pela Resolução $\mathrm{n}^{\circ}$ 536, de 9 de novembro de 2009, para o ano de 2011, e a alteração do referido regulamento, para incluir novo dispositivo (art. 23). 


\begin{tabular}{|l|l|}
\hline Órgão Emissor & ANATEL - Conselho Diretor. \\
\hline Dispositivos & $\begin{array}{l}\text { LGT, Art. 3o, inciso I; LGT, Art. 18, inciso III; LGT, Art. 64, Parágrafo Único; LGT, } \\
\text { Art. 80, caput. }\end{array}$ \\
\hline Altera & $\begin{array}{l}\text { Anexo à Resolução da ANATEL n }{ }^{\circ} \text { 536, de } 9 \text { de novembro de 2009 - Regulamento } \\
\text { de Acompanhamento e Controle das Obrigações de Universalização do Serviço } \\
\text { Telefone Fixo Comutado destinado ao uso do público em geral - STFC. }\end{array}$ \\
\hline Regulamenta & $\begin{array}{l}\text { Lei no 9.472/1997 - Dispõe sobre a organização dos serviços de telecomunicações, a } \\
\text { criação e funcionamento de um órgão regulador e outros aspectos institucionais, nos } \\
\text { termos da Emenda Constitucional no 8, de 1995. }\end{array}$ \\
\hline Publicação & Diário Oficial da União, Seção 1, 09/06/2011, pág. 70 \\
\hline
\end{tabular}

Resolução da ANATEL n 570, de 22 de agosto de 2011 - Aprova o Regulamento para Certificação e Homologação de Acumuladores Chumbo-Ácido Estacionários Regulados por Válvula.

\begin{tabular}{|l|l|}
\hline Órgão Emissor & ANATEL - Conselho Diretor. \\
\hline Anexos & LGT, Art. 19, inciso XIII; LGT, Art. 214, inciso I. \\
\hline Dispositivos & $\begin{array}{l}\text { Resolução da ANATEL no 242/2000 - Aprova o Regulamento para Certificação e } \\
\text { Homologação de Produtos para Telecomunicações. }\end{array}$ \\
\hline Correlata & $\begin{array}{l}\text { Lei no 9.472/1997 - Dispõe sobre a organização dos serviços de telecomunicações, a } \\
\text { criação e funcionamento de um órgão regulador e outros aspectos institucionais, nos } \\
\text { termos da Emenda Constitucional no 8, de 1995. }\end{array}$ \\
\hline Regulamenta & Diário Oficial da União, Seção 1, 13/09/2011, págs. 83-91 \\
\hline
\end{tabular}

Resolução da ANATEL n $^{\circ}$ 571, de 28 de setembro de 2011 - Aprova o Regulamento para definição de formatos e tolerâncias para dados geodésicos fornecidos à Anatel.

\begin{tabular}{|l|l|}
\hline Órgão Emissor & ANATEL - Conselho Diretor. \\
\hline Anexos & LGT, Art. 19, inciso IV; LGT, Art. 19, inciso X; LGT, Art. 173, inciso V. \\
\hline Dispositivos & $\begin{array}{l}\text { Lei n }{ }^{\circ} \text { 9.472/1997 - Dispõe sobre a organização dos serviços de telecomunicações, a } \\
\text { criação e funcionamento de um órgão regulador e outros aspectos institucionais, nos } \\
\text { termos da Emenda Constitucional nº 8, de 1995. }\end{array}$ \\
\hline Regulamenta
\end{tabular}

Resolução da ANATEL n 572, de 28 de setembro de 2011 - Aprova a Norma para Certificação e Homologação de Antenas de Estações Terrenas Operando com Satélites Geoestacionários.

\begin{tabular}{|l|l|}
\hline Órgão Emissor & ANATEL - Conselho Diretor. \\
\hline Anexos & $\begin{array}{l}\text { LGT, Art. 1 }{ }^{\circ} \text {, Parágrafo Único; LGT, Art. 19, inciso XIII; LGT, Art. 170, caput; LGT, } \\
\text { Art. 214, inciso I. }\end{array}$ \\
\hline Dispositivos & $\begin{array}{l}\text { Resolução da ANATEL } n^{\circ} \text { 242/2000 - Aprova o Regulamento para Certificação e } \\
\text { Homologação de Produtos para Telecomunicações. }\end{array}$ \\
\hline Correlata & $\begin{array}{l}\text { Lei no 9.472/1997 - Dispõe sobre a organização dos serviços de telecomunicações, a } \\
\text { criação e funcionamento de um órgão regulador e outros aspectos institucionais, nos } \\
\text { termos da Emenda Constitucional n }{ }^{\circ} \text { 8, de 1995. }\end{array}$ \\
\hline
\end{tabular}


\begin{tabular}{|l|l|}
\hline Publicação & Diário Oficial da União, Seção 1, 05/10/2011, págs. 56-61 \\
\hline
\end{tabular}

Resolução da ANATEL n $^{\circ}$ 573, de 10 de outubro de 2011 - Aprova a Norma para Implantação e Acompanhamento de Liberdade Tarifária no Serviço Telefônico Fixo Comutado Destinado ao Uso Público em Geral, Modalidade Longa Distância Internacional.

Órgão Emissor ANATEL - Conselho Diretor.

\begin{tabular}{|l|l|}
\hline Anexos & \\
\hline Dispositivos & LGT, Art. 104, caput. \\
\hline Regulamenta & $\begin{array}{l}\text { Lei n }{ }^{\circ} 9.472 / 1997 \text { - Dispõe sobre a organização dos serviços de telecomunicações, a } \\
\text { criação e funcionamento de um órgão regulador e outros aspectos institucionais, nos } \\
\text { termos da Emenda Constitucional no } 8 \text {, de } 1995 .\end{array}$ \\
\hline Publicação & Diário Oficial da União, Seção $1,28 / 10 / 2011$, pág. 59 \\
\hline
\end{tabular}

Resolução da ANATEL n $^{0}$ 574, de 28 de outubro de 2011 - Aprova o Regulamento de Gestão da Qualidade do Serviço de Comunicação Multimídia (RGQ-SCM).

\begin{tabular}{|l|l|}
\hline Órgão Emissor & ANATEL - Conselho Diretor. \\
\hline Anexos & \\
\hline Dispositivos & CF, Art. $5^{\circ}$, inciso XXXII; LGT, Art. 3º inciso I; LGT, Art. 19, inciso X. \\
\hline Regulamenta & $\begin{array}{l}\text { Lei }{ }^{\circ} \text { 9.472/1997 - Dispõe sobre a organização dos serviços de telecomunicações, a } \\
\text { criação e funcionamento de um órgão regulador e outros aspectos institucionais, nos } \\
\text { termos da Emenda Constitucional nº 8, de 1995. }\end{array}$ \\
\hline Publicação & Diário Oficial da União, Seção 1, 31/10/2011, págs. 93 - 96 \\
\hline
\end{tabular}

Resolução da ANATEL $\mathbf{n}^{0}$ 575, de 28 de outubro de 2011 - Aprova o Regulamento de Gestão da Qualidade da Prestação do Serviço Móvel Pessoal - RGQ-SMP e altera o Regulamento do Serviço Móvel Pessoal - SMP, aprovado pela Resolução $\mathrm{n}^{\circ}$ 477, de 7 de agosto de 2007, e alterado pelas Resoluções $\mathrm{n}^{\circ} 491$, de 12 de fevereiro de 2008, $\mathrm{n}^{\circ} 509$, de 14 de agosto de 2008, $\mathrm{n}^{\circ} 564$, de 20 de abril de 2011 e n ${ }^{\circ} 567$, de 24 de maio de 2011.

\begin{tabular}{|l|l|}
\hline Órgão Emissor & ANATEL - Conselho Diretor. \\
\hline Anexos & \\
\hline Dispositivos & CF, Art. 5 , inciso XXXII; LGT, Art. 3º inciso I; LGT, Art. 19, inciso X. \\
\hline Altera & $\begin{array}{l}\text { Anexo à Resolução da ANATEL no } 477, \text { de } 7 \text { de agosto de } 2007 \text { - Regulamento do } \\
\text { Serviço Móvel Pessoal - SMP. }\end{array}$ \\
\hline Regulamenta & $\begin{array}{l}\text { Lei } \text { n }^{\circ} \text { 9.472/1997 - Dispõe sobre a organização dos serviços de telecomunicações, a } \\
\text { criação e funcionamento de um órgão regulador e outros aspectos institucionais, nos } \\
\text { termos da Emenda Constitucional no 8, de 1995. }\end{array}$ \\
\hline Publicação & Diário Oficial da União, Seção 1, 31/10/2011, págs. 96-102 \\
\hline
\end{tabular}

Resolução da ANATEL $n^{\circ}$ 576, de 31 de outubro de 2011 - Aprova o Regulamento sobre Critérios de Reajuste das Tarifas das Chamadas do Serviço Telefônico Fixo Comutado (STFC) envolvendo acessos do Serviço Móvel Pessoal (SMP) ou do Serviço Móvel Especializado (SME).

\begin{tabular}{|l|l|}
\hline Órgão Emissor & ANATEL - Conselho Diretor. \\
\hline Anexos & \\
\hline Dispositivos & LGT, Art. 108, caput. \\
\hline
\end{tabular}




\begin{tabular}{|l|l|}
\hline Regulamenta & $\begin{array}{l}\text { Lei } n^{\circ} 9.472 / 1997 \text { - Dispõe sobre a organização dos serviços de telecomunicações, a } \\
\text { criação e funcionamento de um órgão regulador e outros aspectos institucionais, nos } \\
\text { termos da Emenda Constitucional n }{ }^{\circ} \text { 8, de } 1995 .\end{array}$ \\
\hline Publicação & Diário Oficial da União, Seção 1, 04/11/2011, págs. 36-37 \\
\hline
\end{tabular}

Resolução da ANATEL $\mathbf{n}^{\circ}$ 577, de 24 de novembro de 2011 - Altera o Anexo I do Regulamento de Tarifação do Serviço Telefônico Fixo Comutado Destinado ao Uso do Público em Geral - STFC prestado no Regime Público, aprovado pela Resolução no 424, de 6 de dezembro de 2005, bem como o Anexo II à Resolução no 263, de 8 de junho de 2001, Plano Geral de Códigos Nacionais, anexo ao Regulamento de Numeração do STFC, aprovado pela Resolução nº 86, de 30 de dezembro de 1998.

\begin{tabular}{|l|l|}
\hline Órgão Emissor & ANATEL - Conselho Diretor. \\
\hline Anexos & $\begin{array}{l}\text { LGT, Art. 30 inciso IV; LGT, Art. 19, inciso IV; LGT, Art. 64, Parágrafo Único; } \\
\text { LGT, Art. 151, caput. }\end{array}$ \\
\hline Dispositivos & $\begin{array}{l}\text { Anexo à Resolução da ANATEL n } 263 \text {, de } 8 \text { de junho de } 2001 \text { - Plano Geral de } \\
\text { Códigos Nacionais - PGCN. } \\
\text { Anexo à Resolução da ANATEL no 424, de } 6 \text { de dezembro de 2005 - Regulamento } \\
\text { de Tarifação do Serviço Telefônico Fixo Comutado Destinado ou Uso do Público em } \\
\text { Geral - STFC Prestado no Regime Público. }\end{array}$ \\
\hline Regulamenta & $\begin{array}{l}\text { Lei no 9.472/1997 - Dispõe sobre a organização dos serviços de telecomunicações, a } \\
\text { criação e funcionamento de um órgão regulador e outros aspectos institucionais, nos } \\
\text { termos da Emenda Constitucional no 8, de 1995. }\end{array}$ \\
\hline Publicação & Diário Oficial da União, Seção 1, 29/11/2011, pág. 104 \\
\hline
\end{tabular}

Resolução da ANATEL n$^{\circ}$ 578, de 30 de novembro de 2011 - Aprova o Regulamento do Serviço Rádio do Cidadão.

\begin{tabular}{|l|l|}
\hline Órgão Emissor & ANATEL - Conselho Diretor. \\
\hline Anexos & LGT, Art. 127, caput; LGT, Art. 214, inciso I. \\
\hline Dispositivos & $\begin{array}{l}\text { Anexo à Resolução da ANATEL no 444, de 28 de setembro de 2006 - Regulamento } \\
\text { sobre Canalização e Condições de Uso da Faixa de Radiofrequiências de 27 MHz para } \\
\text { o Serviço de Rádio do Cidadão }\end{array}$ \\
\hline Correlata & $\begin{array}{l}\text { Lei no 9.472/1997 - Dispõe sobre a organização dos serviços de telecomunicações, a } \\
\text { criação e funcionamento de um órgão regulador e outros aspectos institucionais, nos } \\
\text { termos da Emenda Constitucional no } 8 \text {, de 1995. }\end{array}$ \\
\hline Publicação & Diário Oficial da União, Seção 1, 06/12/2011, págs. 48-49 \\
\hline
\end{tabular}

\section{Atos Referenciados}

\section{Ato Administrativo}

Ato

Ato da Superintendência de Radiofrequencia e Fiscalização e da Superintendência de Serviços Públicos da ANATEL no 160, de 6 de janeiro de 2011 


\begin{tabular}{|l|l|}
\hline Ementa & $\begin{array}{l}\text { Determinação à Brasil Telecom para que efetue inventário físico do seu patrimônio, } \\
\text { bem como Relação de Bens Reversíveis consistente com o Inventário atualizado do } \\
\text { seu patrimônio }\end{array}$ \\
\hline Órgão Emissor & $\begin{array}{l}\text { ANATEL - Superintendência de Radiofreqüência e Fiscalização; ANATEL - } \\
\text { Superintendência de Serviços Públicos. }\end{array}$ \\
\hline Dispositivos & LGT, Art. 101, caput. \\
\hline Publicação & Diário Oficial da União, Seção 1,10/01/2011, pág. 72 \\
\hline
\end{tabular}

Ato da Superintendência de Radiofrequencia e Fiscalização e da Superintendência de Serviços Públicos da ANATEL no 161, de 6 de janeiro de 2011

\begin{tabular}{|l|l|}
\hline Ementa & $\begin{array}{l}\text { Determinação à Telemar Note Leste S.A. para que efetue inventário físico do seu } \\
\text { patrimônio, bem como a Relação de Bens Reversíveis consistente com o Inventário } \\
\text { atualizado do seu patrimônio. }\end{array}$ \\
\hline Órgão Emissor & $\begin{array}{l}\text { ANATEL - Superintendência de Radiofreqüência e Fiscalização; ANATEL - } \\
\text { Superintendência de Serviços Públicos. }\end{array}$ \\
\hline Dispositivos & LGT, Art. 101, caput. \\
\hline Publicação & Diário Oficial da União, Seção 1,10/01/2011, pág. 72 \\
\hline
\end{tabular}

Ato da Superintendência de Radiofrequencia e Fiscalização e da Superintendência de Serviços Públicos da ANATEL no 162, de 6 de janeiro de 2011

\begin{tabular}{|l|lc|}
\hline Ementa & Determinação à Empresa Brasileira de Telecomunicações S.A. para que efetue \\
\cline { 2 - 2 }
\end{tabular} inventário físico do seu patrimônio, bem como a Relação de Bens Reversíveis consistente com o Inventário atualizado do seu patrimônio.

Órgão Emissor ANATEL - Superintendência de Radiofreqüência e Fiscalização; ANATEL Superintendência de Serviços Públicos.

\begin{tabular}{l|l} 
Dispositivos & LGT, Art. 101, caput. \\
\hline
\end{tabular}

\begin{tabular}{l|l} 
Publicação & Diário Oficial da União, Seção 1, 10/01/2011, págs. 72-73
\end{tabular}

\begin{tabular}{|l|l|}
\hline Ato do Conselho Diretor da ANATEL $\mathbf{n}^{\mathbf{0}} \mathbf{1 . 9 7 0}$, de $\mathbf{1}^{\mathbf{0}}$ de abril de 2011 \\
\hline Ementa & $\begin{array}{l}\text { Anuência prévia à reestruturação societária decorrente da aquisição da Vivo pela } \\
\text { Telefônica. }\end{array}$ \\
\hline Órgão Emissor & ANATEL - Conselho Diretor. \\
\hline Anexos & Anexo \\
\hline Dispositivos & LGT, Art. $7^{\circ}, \S 1^{\text {'}}$; LGT, Art. 19, inciso XIX; LGT, Art. 71, caput. \\
\hline Regulamenta & $\begin{array}{l}\text { Lei } \text { n }^{\mathbf{o}} 9.472 / 1997 \text { - Dispõe sobre a organização dos serviços de telecomunicações, a } \\
\text { criação e funcionamento de um órgão regulador e outros aspectos institucionais, nos } \\
\text { termos da Emenda Constitucional no } 8 \text {, de 1995. }\end{array}$ \\
\hline Publicação & Diário Oficial da União, Seção $1,11 / 04 / 2011$, pág. 73 \\
\hline
\end{tabular}

\begin{tabular}{|l|l|}
\hline \multicolumn{2}{|l|}{ Ato do Conselho Diretor da ANATEL $\mathbf{n}^{\mathbf{0}} \mathbf{2 . 2 8 2}$, de 15 de abril de 2011} \\
\hline Ementa & $\begin{array}{l}\text { Aprova a Edição 2011 do Plano de Atribuição, Destinação e Distribuição de Faixas } \\
\text { de Freqüências no Brasil. }\end{array}$ \\
\hline Órgão Emissor & ANATEL - Conselho Diretor. \\
\hline Anexos & \\
\hline
\end{tabular}




\begin{tabular}{|l|l|}
\hline Dispositivos & $\begin{array}{l}\text { LGT, Art. 19, inciso VIII; LGT, Art. 22, inciso VIII; LGT, Art. 158, caput; LGT, Art. } \\
158, \S 1^{\circ} \text {, inciso III. }\end{array}$ \\
\hline Regulamenta & $\begin{array}{l}\text { Lei no 9.472/1997 - Dispõe sobre a organização dos serviços de telecomunicações, a } \\
\text { criação e funcionamento de um órgão regulador e outros aspectos institucionais, nos } \\
\text { termos da Emenda Constitucional no 8, de 1995. }\end{array}$ \\
\hline Publicação & Diário Oficial da União, Seção 1, 26/04/2011, pág. 59 \\
\hline
\end{tabular}

\begin{tabular}{|l|l|}
\hline \multicolumn{2}{|l|}{ Ato do Conselho Diretor da ANATEL no 5.156, de 22 de julho de 2011} \\
\hline Ementa & $\begin{array}{l}\text { Aprova o modelo de Termo de Autorização do Serviço de Distribuição de Sinais } \\
\text { Multiponto Multicanal (MMDS). }\end{array}$ \\
\hline Órgão Emissor & ANATEL - Conselho Diretor. \\
\hline Anexos & $\begin{array}{l}\text { Anexo - Modelo de Termo de Autorização do Serviço de Distribuição de Sinais } \\
\text { Multiponto Multicanal (MMDS) }\end{array}$ \\
\hline Dispositivos & LGT, Art. 19, inciso XI. \\
\hline Regulamenta & $\begin{array}{l}\text { Lei no 9.472/1997 - Dispõe sobre a organização dos serviços de telecomunicações, a } \\
\text { criação e funcionamento de um órgão regulador e outros aspectos institucionais, nos } \\
\text { termos da Emenda Constitucional no 8, de 1995. }\end{array}$ \\
\hline Publicação & Diário Oficial da União, Seção 1, 26/07/2011, pág. 54 \\
\hline
\end{tabular}

\section{Consulta Pública}

\begin{tabular}{|c|c|}
\hline \multicolumn{2}{|c|}{ Ato do Conselho Diretor da ANATEL $n^{\circ} 5.703$, de 16 de agosto de 2011} \\
\hline Ementa & $\begin{array}{l}\text { Anuência prévia à incorporação da VIVO TELECOMUNICAÇÕES S/A pela } \\
\text { TELECOMUNICAÇÕES DE SÃO PAULO S/A - TELESP. }\end{array}$ \\
\hline Órgão Emissor & ANATEL - Conselho Diretor. \\
\hline Dispositivos & LGT, Art. $7^{\circ}, \S 1^{\circ} ;$ LGT, Art. 19, inciso XIX; LGT, Art. 70, caput. \\
\hline Regulamenta & $\begin{array}{l}\text { Lei } n^{\circ} 9.472 / 1997 \text { - Dispõe sobre a organização dos serviços de telecomunicações, a } \\
\text { criação e funcionamento de um órgão regulador e outros aspectos institucionais, nos } \\
\text { termos da Emenda Constitucional no } 8 \text {, de } 1995 \text {. }\end{array}$ \\
\hline Publicação & Diário Oficial da União, Seção 1, 18/06/2011, pág. 123 \\
\hline
\end{tabular}

\section{Portaria}

\begin{tabular}{|l|l|}
\hline \multicolumn{2}{|l|}{ Portaria do Ministério das Comunicações no 69/2011 } \\
\hline Ementa & $\begin{array}{l}\text { Altera o Regimento Interno do Ministério das Comunicações aprovado pela Portaria } \\
n^{\circ} 401, \text { de } 22 \text { de agosto de 2006. }\end{array}$ \\
\hline Órgão Emissor & Ministério das Comunicações. \\
\hline Dispositivos & LGT, Art. $1^{\circ}$, Parágrafo Único; LGT, Art. 211, Parágrafo Único. \\
\hline Publicação & Diário Oficial da União, Seção 1, 18/03/2011, pág. 71 \\
\hline
\end{tabular}

\section{Portaria ANATEL n $^{\circ}$ 941, de 28 de outubro de 2011}

\begin{tabular}{|l|l|}
\hline Ementa & Dispõe sobre o acesso pelo público em geral aos documentos e informações acostados
\end{tabular} em Procedimento de Apuração de Descumprimento de Obrigações (Pado) e dá outras providências. 


\begin{tabular}{|l|l|}
\hline Órgão Emissor & ANATEL - Conselho Diretor. \\
\hline Dispositivos & LGT, Art. 174, caput. \\
\hline Regulamenta & $\begin{array}{l}\text { Lei no } 9.472 / 1997 \text { - Dispõe sobre a organização dos serviços de telecomunicações, a } \\
\text { criação e funcionamento de um órgão regulador e outros aspectos institucionais, nos } \\
\text { termos da Emenda Constitucional no 8, de 1995. }\end{array}$ \\
\hline Publicação & Diário Oficial da União, Seção 1,31/10/2011, pág. 111 \\
\hline
\end{tabular}

\section{Relatório Anual da ANATEL}

\begin{tabular}{|l|l|}
\hline \multicolumn{2}{|l|}{ Relatório Anual da ANATEL 2010} \\
\hline Órgão Emissor & ANATEL. \\
\hline Dispositivos & LGT, Art. 19, inciso XXVIII. \\
\hline
\end{tabular}

\section{Súmula}

\begin{tabular}{|l|l|}
\hline Súmula da ANATEL no 10, de 15 de março de 2011 \\
\hline Ementa & $\begin{array}{l}\text { A legislação de telecomunicações não impede a indicação de mais de um representante } \\
\text { legal pela exploradora de satélite estrangeiro. O representante legal da Exploradora } \\
\text { de Satélite Estrangeiro pode ser prestadora de serviço de telecomunicações. Caso a } \\
\text { prestadora de serviço de telecomunicações pretenda fazer uso da capacidade espacial } \\
\text { que ela própria representa, a contratação deverá ser formalizada por intermédio de } \\
\text { outro representante legal. O contrato de comercialização de capacidade espacial } \\
\text { decorrente do direito de exploração de satélite estrangeiro deve ser firmado no Brasil } \\
\text { entre o representante legal da exploradora e a prestadora de serviço de } \\
\text { telecomunicações, partes contratuais distintas. }\end{array}$ \\
\hline Órgão Emissor & ANATEL - Conselho Diretor. \\
\hline Dispositivos & LGT, Art. 19, inciso XVI; LGT, Art. 171, § $1^{\circ}$. \\
\hline Regulamenta & $\begin{array}{l}\text { Lei no 9.472/1997 - Dispõe sobre a organização dos serviços de telecomunicações, a } \\
\text { criação e funcionamento de um órgão regulador e outros aspectos institucionais, nos } \\
\text { termos da Emenda Constitucional no 8, de 1995. }\end{array}$ \\
\hline Publicação & Diário Oficial da União, Seção 1, 16/03/2011, pág. 61 \\
\hline
\end{tabular}

\begin{tabular}{|c|c|}
\hline \multicolumn{2}{|c|}{ Súmula da ANATEL $\mathrm{n}^{0}$ 11, de 17 de novembro de 2011} \\
\hline Ementa & $\begin{array}{l}\text { Estão incluídas na base de cálculo do ônus contratual previsto nos Contratos de } \\
\text { Concessão de } 2006 / 2010 \text {, para prestação do STFC, dentre outras, as receitas de } \\
\text { interconexão, PUC, e, ainda, de outros serviços adicionais e receitas operacionais } \\
\text { inerentes ao STFC. }\end{array}$ \\
\hline Órgão Emissor & ANATEL - Conselho Diretor. \\
\hline Dispositivos & LGT, Art. 19, inciso XVI; LGT, Art. 99, $\S 1^{\circ}$; LGT, Art. 207, $\S 1^{\circ}$. \\
\hline Regulamenta & $\begin{array}{l}\text { Lei no 9.472/1997 - Dispõe sobre a organização dos serviços de telecomunicações, a } \\
\text { criação e funcionamento de um órgão regulador e outros aspectos institucionais, nos } \\
\text { termos da Emenda Constitucional } n^{\circ} 8 \text {, de } 1995 \text {. }\end{array}$ \\
\hline Publicação & Diário Oficial da União, Seção 1, 24/11/2011, pág. 97 \\
\hline
\end{tabular}

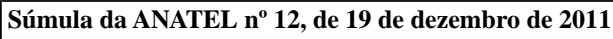




\begin{tabular}{|l|l|}
\hline Ementa & $\begin{array}{l}\text { Não cabe recurso contra ato administrativo que determine ou formalize a instauração } \\
\text { de processo administrativo sancionador. }\end{array}$ \\
\hline Órgão Emissor & ANATEL - Conselho Diretor. \\
\hline Dispositivos & CF, TíTULO VI - Da Tributação e do Orçamento; LGT, Art. 19, inciso XVI. \\
\hline Regulamenta & $\begin{array}{l}\text { Lei no } 9.472 / 1997 \text { - Dispõe sobre a organização dos serviços de telecomunicações, a } \\
\text { criação e funcionamento de um órgão regulador e outros aspectos institucionais, nos } \\
\text { termos da Emenda Constitucional no } 8 \text {, de 1995. }\end{array}$ \\
\hline Publicação & Diário Oficial da União, Seção 1, 20/12/2011, pág. 87 \\
\hline
\end{tabular}




\section{Índice Alfabético e Remissivo}

\section{Símbolos}

\section{2,5 GHz}

(ver Faixa de 2,5 GHz)

450 MHz, 364

[Decreto $\left.\mathrm{n}^{\circ} 7.512 / 2011\right]$

4G, 364

[Decreto $\left.\mathrm{n}^{\circ} 7.512 / 2011\right]$

\section{A}

\section{Acesso a Informações}

disciplina legal do acesso a informações, 363

[Lei ${ }^{\circ} 12.527$, de 18 de novembro de 2011]

Procedimento Administrativo para Apuração de Descumprimento de Obrigações (Agência Nacional de Telecomunicações)

publicidade dos Pados da Anatel, 375

[Portaria ANATEL n ${ }^{\circ}$ 941/2011]

Acesso a Serviços de Interesse Público e Uso de Radiofrequência por tais Serviços, 356

Acesso às Telecomunicações, 342

Acumulador

Chumbo-Ácido

Estacionário Regulado por

Válvula

norma para certificação e homologação de, 371

[Resolução da ANATEL n ${ }^{\circ}$ 570/2011]

\section{Adaptação Compulsória}

das prestadoras de TVC, TVA, MMDS

e DTH à regulamentação do Serviço de Acesso Condicionado, 362

[Lei $\mathrm{n}^{\circ}$ 12.485/2011]

Administração do Setor de

Telecomunicações, 337

Administração Ordenadora (ver Poder de Polícia)

Agência Nacional do Cinema

competência para regulação e fiscalização da programação e do empacotamento na comunicação audiovisual de acesso condicionado, 362

[Lei $\left.n^{\circ} 12.485 / 2011\right]$

ANATEL, 357

ANCINE, 361

(ver Agência Nacional do Cinema)

Antena para Estações Terrenas

norma para certificação e homologação de, 371

[Resolução da ANATEL n ${ }^{\circ}$ 572, de 28 de setembro de 2011]

Antenas, 335

Anuência Prévia

Vivo Participações S/A anuência prévia à incorporação da Vivo pela Telesp, 375

[Ato do Conselho Diretor da ANATEL $\left.\mathrm{n}^{\circ} 5.703 / 2011\right]$

anuência prévia à reestruturação societária decorrente da aquisição da Vivo pela Telefônica, 374

[Ato do Conselho Diretor da ANATEL $\left.\mathrm{n}^{\circ} 1.970 / 2011\right]$

Aplicações de Telecomunicações, 355

Aplicações Educacionais, 355

Área de Baixa Densidade Populacional (ver Zona Rural)

Área de Tarifa Básica

Regulamento sobre Áreas Locais para

o STFC aprovação do, 367

[Resolução da ANATEL n 560/2011]

Área de Tarifação

sua alteração para o município de Altamira do Paraná, 373

[Resolução da ANATEL n ${ }^{\circ}$ 577, de 24 de novembro de 2011] 


\section{Área Local}

Regulamento sobre Áreas Locais para

o STFC aprovação do, $\mathbf{3 6 7}$

Área Rural

[Resolução da ANATEL nº 560/2011]

\section{(ver Zona Rural)}

\section{Artista}

vedação de contratação de talentos artísticos nacionais de qualquer natureza, inclusive direitos sobre obras de autores nacionais por parte de prestadora de serviços de telecomunicações de interesse coletivo, $\mathbf{3 6 2}$

[Lei $\mathrm{n}^{\circ}$ 12.485/2011]

Aspectos Históricos, 335

ATB

(ver Área de Tarifa Básica)

Ato de Concentração Econômica (ver Competição)

Atores no Setor de Telecomunicações, 357

\section{Atribuição, Destinação e} Designação de Radiofrequência, 336

\section{Aumento Arbitrário de Lucros}

Serviço Telefônico Fixo Comutado aumento arbitrário de lucros como causa de restabelecimento do regime de Tarifas Fixadas no STFC, Modalidade Longa Distância Internacional, $\mathbf{3 7 2}$

[Resolução da ANATEL n ${ }^{\circ}$ 573, de 10 de outubro de 2011]

\section{Avaliação de Conformidade (ver Certificação)}

\section{B}

\section{Baixa Densidade Populacional (ver Zona Rural)}

Banda Larga, 356

Banda Larga, 361

[Lei $\left.{ }^{\circ} 12.431 / 2011\right]$
Anuência Prévia

dever de expansão da banda larga derivado dos condicionamentos à anuência prévia de reestruturação societária decorrente da aquisição da Vivo pela Telefônica, 374

[Ato do Conselho Diretor da ANATEL $\mathrm{n}^{\mathrm{o}} 1.970 / 2011$ ]

esclarecimento do condicionamento imposto para aquisição da Vivo pela Telefônica de disponibilização gratuita de infraestrutura de banda larga para uso não comercial pela RNP para interiorização da rede de educação e pesquisa avançada do país, 375 [Ato do Conselho Diretor da ANATEL $\left.\mathrm{n}^{\circ} 5.703 / 2011\right]$

Programa Nacional de Banda Larga aprovação de medidas tributárias de isenção da Contribuição para o PIS/Pasep e da Cofins para modens e bens de informática no âmbito do Programa de Inclusão Digital, por ocasião da implementação do, 361

[Lei n $\left.{ }^{\circ} 12.431 / 2011\right]$

aprovação de medidas tributárias de isenção da Contribuição para o PIS/Pasep e da Cofins para tablets no âmbito do Programa de Inclusão Digital, por ocasião da implementação do, 362

[Lei ${ }^{\circ} 12.507 / 2011$ ]

Qualidade do Serviço

fixação de prazo até 31 de outubro de 2011 para adoção, pela Anatel, de padrões de qualidade para os serviços de telecomunicações que suportam o acesso à Internet em banda larga, inclusive parâmetros de velocidade efetiva de conexão mínima e média, disponibilidade do serviço, bem como critério de publicidade e transparência para aferição da qualidade percebida pelos usuários, 364 
[Decreto $\left.n^{\circ} 7.512 / 2011\right]$

\section{Banda Larga Móvel de Quarta Geração (ver 4G)}

Banda Larga Móvel de Quarta Geração

dever de licitação, até 30 de abril de 2012, das subfaixas de radiofrequências de $2.500 \mathrm{MHz}$ a $2.690 \mathrm{MHz}$ para a banda larga móvel de alta velocidade, com tecnologia de quarta geração, 364

[Decreto $\left.\mathrm{n}^{\mathrm{o}} 7.512 / 2011\right]$

\section{Bem Reversível}

Inventário de Bens Reversíveis determinação de 2011 à Brasil Telecom S/A para que efetuasse o inventário físico do seu patrimônio e dos seus bens reversíveis, 373

[Ato da Superintendência de Radiofrequencia e Fiscalização e da Superintendência de Serviços Públicos da ANATEL n ${ }^{\circ}$ 160/ 2011]

determinação de 2011 à Empresa Brasileira de Telecomunicações S.A. para que efetuasse o inventário físico de todos os seus bens e dos bens reversíveis, 374

[Ato da Superintendência de Radiofrequencia e Fiscalização e da Superintendência de Serviços Públicos da ANATEL $n^{\circ}$ 162/2011]

determinação de 2011 à Telemar Norte Leste S.A. para que efetuasse o inventário físico de todos os seus bens e dos bens reversíveis, 374

[Ato da Superintendência de Radiofrequencia e Fiscalização e da Superintendência de Serviços Públicos da ANATEL n ${ }^{\circ}$ 161/2011]

\section{BRASIL TELECOM S.A}

Bem Reversível determinação de 2011 à Brasil Telecom S/A para que efetuasse o inventário físico do seu patrimônio e dos seus bens reversíveis, $\mathbf{3 7 3}$

[Ato da Superintendência de Radiofrequencia e Fiscalização e da Superintendência de Serviços Públicos da ANATEL n ${ }^{\circ}$ 160/ 2011]

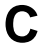

CADE, 357

(ver Conselho Administrativo de Defesa Econômica)

Campo

(ver Zona Rural)

Canalização

(ver Distribuição de Canais)

Capacidade Espacial

(ver Provimento de Capacidade de Satélite)

Centro de Atendimento

(ver Centro de Atendimento

(Indicadores de Qualidade do STFC))

(ver Centro de Atendimento (Serviço Móvel Pessoal))

(ver Centro de Atendimento (Serviços de Televisão por Assinatura))

Centro de Atendimento

(Indicadores de Qualidade do STFC), 370

(ver também Serviço de Atendimento ao Consumidor)

[Resolução da ANATEL nº 567/2011]

Centro de Atendimento (Serviço

Móvel Pessoal), 370

(ver também Serviço de Atendimento ao Consumidor)

[Resolução da ANATEL n 567/2011]

Centro de Atendimento (Serviços de Televisão por Assinatura), 370 (ver também Serviço de Atendimento ao Consumidor)

[Resolução da ANATEL n ${ }^{\circ}$ 567/2011]

Centro de Atendimento, 370 
(ver também Serviço de Atendimento ao Consumidor)

[Resolução da ANATEL nº 567/2011]

Centro de Atendimento para Intermediação da Comunicação a Portadores de Necessidades Especiais, 370

(ver também Serviço de Atendimento ao Consumidor)

[Resolução da ANATEL n 567/2011]

\section{Certificação}

Acumulador

Chumbo-Ácido

Estacionário Regulado por Válvula, 371

[Resolução da ANATEL n ${ }^{\circ}$ 570/2011]

Antena para Estações Terrenas, 371

[Resolução da ANATEL n ${ }^{\circ}$ 572, de 28 de setembro de 2011]

\section{Certificação / Homologação, 335}

\section{Cidades Digitais}

Tecnologias de Informação e

Comunicação

sua apropriação pela gestão pública local e pela população como objetivo do Projeto de Implantação e Manutenção das Cidades Digitais, 364

[Portaria MC n 376/2011]

Classificações de Serviços no Setor de Telecomunicações, 345

\section{Coletivo}

(ver Serviço de Interesse Coletivo)

\section{Comercial}

(ver Peça Publicitária)

\section{Compensação Financeira}

Serviço de Acesso Condicionado indevida compensação financeira na adequação das outorgas e autorizações de TVC, MMDS e DTH para o, 362

[Lei ${ }^{\circ}$ 12.485/2011]

Serviço de Distribuição de Sinais de Televisão e de Áudio por Assinatura Via Satélite indevida compensação financeira na adequação das autorizações de DTH para o, 362

[Lei ${ }^{\circ}$ 12.485/2011]

Serviço de Distribuição de Sinais

Multiponto Multicanal

indevida compensação financeira na adequação das autorizações de MMDS para o, 362

[Lei ${ }^{\circ}$ 12.485/2011]

Serviço de TV a Cabo

indevida compensação financeira na adequação das outorgas de TVC para o, $\mathbf{3 6 2}$

[Lei ${ }^{\circ}$ 12.485/2011]

Televisão por Assinatura (Espécie de

Serviço Especial)

devida compensação financeira na adequação das autorizações de TVA para 0,362

[Lei $\left.{ }^{\circ} 12.485 / 2011\right]$

\section{Competição}

Sistema Brasileiro de Defesa da

Concorrência

lei regente, $\mathbf{3 6 3}$

[Lei ${ }^{\circ} 12.529$, de 30 de novembro de 2011]

Comunicação Audiovisual de Acesso Condicionado

disciplina legal da, $\mathbf{3 6 2}$

[Lei ${ }^{\circ}$ 12.485/2011]

Comunicação de Massa, 346

Comunicação Multimídia, 346

Concessão (regras aplicáveis), 338

Concessão

(ver também Concessionária)

Bem Reversível

determinação de 2011 à Brasil Telecom S/A para que efetuasse o inventário físico do seu patrimônio e dos seus bens reversíveis, $\mathbf{3 7 3}$

[Ato da Superintendência de Radiofrequencia e Fiscalização e da Superintendência de Serviços Públicos da ANATEL $n^{\circ}$ 160/ 2011] 
determinação de 2011 à Empresa Brasileira de Telecomunicações S.A. para que efetuasse o inventário físico de todos os seus bens e dos bens reversíveis, $\mathbf{3 7 4}$

[Ato da Superintendência de Radiofrequencia e Fiscalização e da Superintendência de Serviços Públicos da ANATEL no 162/2011]

determinação de 2011 à Telemar

Norte Leste S.A. para que efetuasse o inventário físico de todos os seus bens e dos bens reversíveis, 374

[Ato da Superintendência de Radiofrequencia e Fiscalização e da Superintendência de Serviços Públicos da ANATEL $n^{\circ} 161 / 2011$ ]

\section{Concessionária}

(ver também Concessão)

Bem Reversível

determinação de 2011 à Empresa Brasileira de Telecomunicações S.A. para que efetuasse o inventário físico de todos os seus bens e dos bens reversíveis, 374

[Ato da Superintendência de Radiofrequencia e Fiscalização e da Superintendência de Serviços Públicos da ANATEL no 162/2011]

determinação de 2011 à Telemar Norte Leste S.A. para que efetuasse o inventário físico de todos os seus bens e dos bens reversíveis, 374

[Ato da Superintendência de Radiofrequencia e Fiscalização e da Superintendência de Serviços Públicos da ANATEL n ${ }^{\circ}$ 161/2011]

Bens Reversíveis determinação de 2011 à Brasil Telecom S/A para que efetuasse o inventário físico do seu patrimônio e dos seus bens reversíveis, $\mathbf{3 7 3}$

[Ato da Superintendência de Radiofrequencia e Fiscalização e da
Superintendência de Serviços Públicos da ANATEL n ${ }^{\circ}$ 160/ 2011]

\section{Concorrência}

(ver Competição)

Concorrência no Setor de Telecomunicações, 341

Condições de Uso de Radiofrequência e Canalização (Distribuição de Canais), 336

Conselho Administrativo de Defesa Econômica, 363

(ver também Sistema Brasileiro de Defesa da Concorrência)

[Lei ${ }^{\circ} 12.529$, de 30 de novembro de 2011]

\section{Consumidor}

Serviço de Atendimento ao Consumidor

direito do consumidor de acesso ao conteúdo das gravações das chamadas por ele efetuadas à central de informação e de atendimento ao usuário da prestadora, 370

[Resolução da ANATEL no 567/2011]

\section{Conteúdo Brasileiro, 362}

[Lei ${ }^{\circ}$ 12.485/2011]

Contrato de Comercialização de Capacidade Espacial

, deve ser firmado no Brasil entre o representante legal da exploradora e a prestadora de serviço de telecomunicações, partes contratuais distintas, 376

[Súmula da ANATEL no 10, de 15 de março de 2011]

Controle Social, Hierárquico e Interorgânico, 344

Convergência, 345

Coordenadas Geodésicas

Regumento para definição de formas e tolerâncias para dados geodésicos fornecidos à Anatel aprovação do, 371

[Resolução da ANATEL n ${ }^{\circ}$ 571/2011] 
Coordenadas Geodésicas, 371

[Resolução da ANATEL nº 571/2011]

D

Destinação de Radiofreqüências (ver também Destinação de Radiofreqüências) para o DTH, 369

[Resolução da ANATEL n 563/2011] para o Serviço de Radiodifusão por Satélite, $\mathbf{3 6 9}$

[Resolução da ANATEL n n 563/2011] para o SLP em aplicações de exploração da Terra por satélite, $\mathbf{3 6 8}$

\section{Direct-to-Home}

[Resolução da ANATEL n ${ }^{\circ}$ 561/2011]

(ver Serviço de Distribuição de Sinais de Televisão e de Áudio por Assinatura Via Satélite)

Direito Administrativo, 355

Direito da Concorrência, 354

Direito de Exploração de Imagem vedação de aquisição ou de financiamento de aquisição de direitos de exploração de imagens de eventos de interesse nacional por parte de prestadora de serviços de telecomunicações de interesse coletivo, $\mathbf{3 6 2}$

[Lei ${ }^{\circ}$ 12.485/2011]

Direito do Consumidor, 354

Distribuição de Canais

(ver também Espectro de Radiofreqüências)

Regulamento sobre Canalização e Condições de Uso de Radiofrequências na Faixa de 148 $\mathrm{MHz}$ a $174 \mathrm{MHz}, \mathbf{3 7 0}$

[Resolução da ANATEL $n^{\circ}$ 568/2011]

Regulamento sobre Condições de Uso de Radiofrequiências nas Faixas de $25,35 \mathrm{GHz}$ a $28,35 \mathrm{GHz}, 29,10 \mathrm{GHz}$ a $29,25 \mathrm{GHz}$ e $31,00 \mathrm{GHz}$ a 31,30 $\mathrm{GHz}$

aprovação do, $\mathbf{3 6 8}$
[Resolução da ANATEL no 561/2011]

Distribuição de Sinais Multiponto Multicanal

(ver Serviço de Distribuição de Sinais Multiponto Multicanal)

DTH

(ver Serviço de Distribuição de Sinais de Televisão e de Áudio por Assinatura Via Satélite)

DTH (Direct to Home - Serviço de Distribuição de Sinais de Televisão e de Áudio por Assinatura Via Satélite), 350

E

Educação, 364-365

(ver também Radiodifusão Educativa)

[Portaria MC n ${ }^{\circ} 256$, de 6 de julho de 2011]

[Portaria $\mathrm{MC} \mathrm{n}^{\circ}$ 420/2011]

Educação e Pesquisa, 343

Embratel

Bem Reversível

determinação de 2011 à Empresa Brasileira de Telecomunicações S.A. para que efetuasse o inventário físico de todos os seus bens e dos bens reversíveis, $\mathbf{3 7 4}$

[Ato da Superintendência de Radiofrequencia e Fiscalização e da Superintendência de Serviços Públicos da ANATEL n ${ }^{\circ}$ 162/2011]

\section{Emergência}

(ver Serviço de Emergência)

\section{Ensino, 364}

(ver também Escola Pública)

[Decreto ${ }^{\circ} 7.512 / 2011$ ]

Equ i p a m e n tos

d e

Telecomunicações, 335

\section{Escola Pública}

(ver também Ensino)

definição do princípio de atendimento para acesso à Internet em banda larga para escolas públicas rurais quando da licitação das subfaixas de 
radiofrequência de $451 \mathrm{MHz}$ a 458 MHz e de $461 \mathrm{MHz}$ a $468 \mathrm{MHz}, 364$ [Decreto $\left.{ }^{\circ} 7.512 / 2011\right]$

Espécies de Outorga, 338

Espectro de Radiofrequência, 336

Espectro de Radiofreqüências

(ver também Distribuição de Canais)

Plano de Atribuição de Espectro de

Radiofreqüências

Edição 2011 do, 374

[Ato do Conselho Diretor da ANATEL $\left.n^{\circ} 2.282 / 2011\right]$

\section{Estação de Telecomunicações}

Coordenadas Geodésicas

formatos e tolerâncias para dados geodésicos fornecidos à Anatel, 371

[Resolução da ANATEL n ${ }^{\circ}$ 571/2011]

\section{Estação Móvel}

(ver Estação Móvel (Serviço Móvel Pessoal))

Estação Móvel (Serviço Móvel Pessoal)

Localização

parâmetros de localização da Estação Móvel do Usuário do SMP remetente de mensagem de texto a serviço público de emergência, 369

[Resolução da ANATEL no ${ }^{\circ}$ 644/2011]

Estações de Telecomunicações, 335 Exploradora de Satélite

Estrangeiro, 376

(ver também Satélite Estrangeiro)

[Súmula da ANATEL $\mathrm{n}^{\circ} 10$, de 15 de março de 2011]

requisitos para constituição de representante legal da, $\mathbf{3 7 6}$

[Súmula da ANATEL n ${ }^{\circ}$ 10, de 15 de março de 2011]

\section{Faixa de 2,5 GHz}

dever de licitação, até 30 de abril de 2012, das subfaixas de radiofrequências de $2.500 \mathrm{MHz}$ a $2.690 \mathrm{MHz}$ para a banda larga móvel de alta velocidade, com tecnologia de quarta geração, 364

[Decreto $\left.\mathrm{n}^{\circ} 7.512 / 2011\right]$

\section{Faixa de $450 \mathrm{MHz}$}

(ver $450 \mathrm{MHz}$ )

\section{Faixa de $450 \mathrm{MHz}$}

Banda Larga

definição do princípio de atendimento para acesso à Internet em banda larga para escolas públicas rurais quando da licitação das subfaixas de radiofrequência de $451 \mathrm{MHz}$ a $458 \mathrm{MHz}$ e de $461 \mathrm{MHz}$ a 468 $\mathrm{MHz}, 364$

[Decreto $\mathrm{n}^{\circ}$ 7.512/2011]

Escola Pública

definição do princípio de atendimento para acesso à Internet em banda larga para escolas públicas rurais quando da licitação das subfaixas de radiofrequência de $451 \mathrm{MHz}$ a $458 \mathrm{MHz}$ e de $461 \mathrm{MHz}$ a 468 MHz, 364

[Decreto $\left.{ }^{\circ} 7.512 / 2011\right]$

Universalização

dever de licitação, por parte da Anatel, até 30 de abril de 2012, de autorização de uso de radiofrequência de $451 \mathrm{MHz}$ a $458 \mathrm{MHz}$ e de $461 \mathrm{MHz}$ a 468 $\mathrm{MHz}$ para fins de ampliação da penetração dos serviços de telecomunicações de voz e de dados, 364

[Decreto $\left.\mathrm{n}^{\mathrm{O}} 7.512 / 2011\right]$

\section{Faixa de Radiofreqüência}


(ver Espectro de Radiofreqüências)

Fiscalização

(ver também Poder de Polícia)

Processo Administrativo

não cabe recurso contra ato administrativo que determine ou formalize a instauração de processo administrativo sancionador, 376

[Súmula da ANATEL n ${ }^{\circ} 12$, de 19 de dezembro de 2011]

Fiscalização das Telecomunicações, 337

FNC

(ver Fundo Nacional da Cultura)

Fronteira

utilização da faixa de $148 \mathrm{MHz}$ a 174

$\mathrm{MHz}, 370$

[Resolução da ANATEL no 568/2011]

Fronteiras, 370

[Resolução da ANATEL no 568/2011]

Fundamentos, 335

Fundo Nacional da Cultura

vedação de sua utilização por prestadoras do TVC, MMDS, DTH e TVA, bem como suas controladas, controladoras ou coligadas, $\mathbf{3 6 2}$

[Lei $\left.{ }^{\circ} 12.485 / 2011\right]$

G

\section{Gratuidade}

Serviço Público de Emergência

gratuidade do envio de mensagens de texto a, $\mathbf{3 6 9}$

[Resolução da ANATEL no 564/2011]

I

\section{Infraestrutura e Recursos do Setor} de Telecomunicações, 335

\section{Instauração}

Processo Administrativo

não cabe recurso contra ato administrativo que determine ou formalize a instauração de processo administrativo sancionador, 376

[Súmula da ANATEL no 12, de 19 de dezembro de 2011]

\section{Interesse Coletivo}

(ver Serviço de Interesse Coletivo)

Internet, 355

INTERNET

(ver também Serviço de Valor

Adicionado)

Qualidade do Serviço

fixação de prazo até 31 de outubro de 2011 para adoção, pela Anatel, de padrões de qualidade para os serviços de telecomunicações que suportam o acesso à Internet em banda larga, inclusive parâmetros de velocidade efetiva de conexão mínima e média, disponibilidade do serviço, bem como critério de publicidade e transparência para aferição da qualidade percebida pelos usuários, 364

[Decreto $\left.{ }^{\circ} 7.512 / 2011\right]$

Serviço de Conexão à INTERNET

como serviço de valor adicionado, 365

[Resolução $\mathrm{n}^{\circ}$ 4, de 16 de setembro de 2011]

\section{Inventário de Bens Reversíveis}

determinação de 2011 à Brasil Telecom S/A para que efetuasse o inventário físico do seu patrimônio e dos seus bens reversíveis, $\mathbf{3 7 3}$

[Ato da Superintendência de Radiofrequencia e Fiscalização e da Superintendência de Serviços Públicos da ANATEL n $\left.{ }^{\circ} 160 / 2011\right]$

determinação de 2011 à Empresa Brasileira de Telecomunicações S.A. para que efetuasse o inventário físico de todos os seus bens e dos bens reversíveis, 374

[Ato da Superintendência de Radiofrequencia e Fiscalização e da 
Superintendência de Serviços Públicos da ANATEL n ${ }^{\circ}$ 162/2011] determinação de 2011 à Telemar Norte Leste S.A. para que efetuasse o inventário físico de todos os seus bens e dos bens reversíveis, 374

[Ato da Superintendência de Radiofrequencia e Fiscalização e da Superintendência de Serviços Públicos da ANATEL $n^{\circ} 161 / 2011$ ]

\section{ISDB-T}

(ver Padrão ISDB-T)

ISDB-TB

(ver Sistema Brasileiro de Televisão Digital Terrestre)

\section{$\mathbf{L}$}

\section{Liberdade de Participação, 338}

\section{Liberdade Tarifária}

Serviço Telefônico Fixo Comutado sua implantação e acompanhamento no STFC Longa Distância Internacional, 372

[Resolução da ANATEL n ${ }^{\circ}$ 573, de 10 de outubro de 2011]

\section{Licença para Funcionamento de} Estação

Recadastramento de estação ajuste de informações de coordenadas geodésicas não exige novo licenciamento ou pagamento de taxas, desde que não associada a uma real mudança do local de instalação, 371

[Resolução da ANATEL nº 571/2011]

\section{M}

\section{Mensagem de Texto}

Gratuidade

no envio de mensagens de texto a serviços públicos de emergência no âmbito do SMP, 369

[Resolução da ANATEL n ${ }^{\circ}$ 564/2011] Serviço Móvel Pessoal regulamentação do envio de mensagem de texto aos serviços públicos de emergência no, $\mathbf{3 6 9}$

[Resolução da ANATEL no ${ }^{\circ}$ 564/2011]

Metas de Qualidade, 372

[Resolução da ANATEL n ${ }^{\circ}$ 574, de 28 de outubro de 2011] [Resolução nº 575/2011]

Metas de Universalização, 343

Metas de Universalização

(ver também Plano Geral de Metas de Universalização)

Regulamento de Acompanhamento e Controle das Obrigações de Universalização do STFC possibilidade de prorrogação de prazos por ato do Conselho Diretor da Anatel, 370

[Resolução da ANATEL n ${ }^{\circ}$ 569/2011] prorrogação de prazos referentes a campanhas de divulgação e divulgação a órgãos públicos, $\mathbf{3 7 0}$ [Resolução da ANATEL no 569/2011]

Ministério da Justiça, 358

Ministério das Comunicações, 358

Ministério das Comunicações

Regimento Interno do Ministério das Comunicações aprovação do, $\mathbf{3 6 5}, \mathbf{3 7 5}$

[Portaria do Ministério das Comunicações $n^{\circ}$ 69/2011] [Portaria $\mathrm{MC} \mathrm{n}^{\circ}$ 69, de 17 de março de 2011]

Ministro das Comunicações (ver Ministério das Comunicações) MMDS

(ver Serviço de Distribuição de Sinais Multiponto Multicanal)

MMDS (Multichannel Multipoint Distribution Service - Serviço de Distribuição de Sinais Multiponto Multicanal), 351

\section{Modem}

Programa Nacional de Banda Larga aprovação de medidas tributárias de isenção da Contribuição para o PIS/Pasep e da Cofins para 
modens e bens de informática no âmbito do Programa de Inclusão Digital, por ocasião da implementação do, 361

[Lei $\left.\mathrm{n}^{\circ} 12.431 / 2011\right]$

\section{Multichannel \\ Distribution Service \\ (ver Serviço de Distribuição de Sinais \\ Multiponto Multicanal)}

\section{$\mathbf{N}$}

Norma Complementar do Serviço de Radiodifusão Comunitária, 365

[Portaria MC nº 462/2011]

O

Obrigações de Universalização (ver Universalização)

Oi

(ver TELEMAR NORTE LESTE S.A.)

\section{Onerosidade}

Serviço Telefônico Fixo Comutado inclusão, na base de cálculo do ônus contratual previsto nos contratos de concessão do STFC de 2006/2010, das receitas de interconexão, PUC e serviços adicionais e receitas operacionais inerentes ao STFC, 376

[Súmula da ANATEL no 11, de 17 de novembro de 2011]

Operadora de Telecomunicações, 374-375

(ver também Telefônica)

[Ato do Conselho Diretor da ANATEL $\mathrm{n}^{\circ}$

1.970/ 2011] [Ato do Conselho Diretor da ANATEL n ${ }^{\circ}$ 5.703/2011]

Órbita, 336 (ver também Satélite)

Órbita e Satélite, 336

Outorgas, 338

$\mathbf{P}$

PADO

(ver Procedimento Administrativo para Apuração de Descumprimento de Obrigações (Agência Nacional de Telecomunicações))

Padrão ISDB-T adoção pelo Brasil do, 366

[Portaria MC n 491/011]

PDG

(ver Programa de Dispêndios Globais (Empresas Estatais Federais))

Peça Publicitária, 362

[Lei $n^{\circ} 12.485 / 2011$ ]

Artista

possibilidade de sua contratação por prestadora de serviços de telecomunicações de interesse coletivo para fins de produção de peças publicitárias, 362

[Lei ${ }^{\circ}$ 12.485/2011]

Direito de Exploração de Imagem possibilidade de sua aquisição ou de financiamento de aquisição por prestadora de serviços de telecomunicações de interesse coletivo para fins de produção de peças publicitárias, 362

[Lei ${ }^{\circ}$ 12.485/2011]

Pesquisa \& Desenvolvimento, 343

PGMU

(ver Plano Geral de Metas de Universalização)

Plano de Atribuição de Espectro de Radiofreqüências

Destinação de Radiofrequiências Edição 2011 do, 374

[Ato do Conselho Diretor da ANATEL $\left.\mathrm{n}^{\mathrm{o}} 2.282 / 2011\right]$ 
Plano Geral de Metas de Presidência da República, 358 Universalização (ver também Metas de Universalização)

a partir de 30 de junho de 2011, 364

[Decreto $\left.{ }^{\circ} 7.512 / 2011\right]$

Plano Nacional de Banda Larga, 361

[Lei ${ }^{\circ}$ 12.431/2011]

Planos de Serviços, 340

PNBL

(ver Programa Nacional de Banda Larga)

PNBL, 361

[Lei $\left.{ }^{\circ} 12.431 / 2011\right]$

Poder de Polícia

(ver também Fiscalização)

Processo Administrativo

não cabe recurso contra ato administrativo que determine ou formalize a instauração de processo administrativo sancionador, 376

[Súmula da ANATEL n ${ }^{\circ}$ 12, de 19 de dezembro de 2011]

Poder Executivo, 358

Política Industrial, 341

Política Tarifária, 340

Políticas de Telecomunicações, 340

PPB

(ver Processo Produtivo Básico)

Preço Discriminatório

sua vedação em atividades de produção, programação, empacotamento ou distribuição de comunicação audiovisual de acesso condicionado, $\mathbf{3 6 2}$

[Lei $\left.{ }^{\circ} 12.485 / 2011\right]$

\section{Preço Público}

(ver também Tarifa)

devido na prorrogação da concessão de serviços públicos de telecomunicações, $\mathbf{3 7 6}$

[Súmula da ANATEL n ${ }^{\circ}$ 11, de 17 de novembro de 2011]

Prestador de Serviço de Telecomunicações (ver Operadora de Telecomunicações)

Prestadora / Operadora, 359

Princípio da Generalidade (ver Universalização)

Procedimento Administrativo para Apuração de Descumprimento de Obrigações

(ver Procedimento Administrativo para Apuração de Descumprimento de Obrigações (Agência Nacional de Telecomunicações))

Procedimento Administrativo para Apuração de Descumprimento de Obrigações (Agência Nacional de Telecomunicações)

publicidade dos Pados da Anatel, 375

[Portaria ANATEL n ${ }^{\circ}$ 941/2011]

Processo Administrativo, 376

[Súmula da ANATEL $\mathrm{n}^{\circ}$ 12, de 19 de dezembro de 2011]

Recurso

não cabe recurso contra ato administrativo que determine ou formalize a instauração de processo administrativo sancionador, 376

[Súmula da ANATEL nº 12, de 19 de dezembro de 2011]

Sigilo

disciplina legal do acesso a informações, $\mathbf{3 6 3}$

[Lei ${ }^{\circ} 12.527$, de 18 de novembro de 2011]

publicidade dos Pados da Anatel, 375

[Portaria ANATEL n ${ }^{\circ}$ 941/2011]

Processo Administrativo, 376

[Súmula da ANATEL n ${ }^{\circ} 12$, de 19 de dezembro de 2011] 


\section{Processo Produtivo Básico}

de modens e bens de informática no âmbito do Programa Nacional de Banda Larga, 361

[Lei ${ }^{\circ}$ 12.431/2011]

de tablets, $\mathbf{3 6 2}$

[Lei $\mathrm{n}^{\circ}$ 12.507/2011]

\section{Programa de Dispêndios Globais (Empresas Estatais Federais) \\ PDG para 2012, 364 \\ [Decreto $\left.n^{\circ} 7.628 / 2011\right]$}

\section{Programa Nacional de Banda \\ Larga \\ (ver Banda Larga) \\ (ver Plano Nacional de Banda Larga) (ver PNBL)}

Programa Nacional de Banda

\section{Larga}

aprovação de medidas tributárias de isenção da Contribuição para o PIS/Pasep e da Cofins para modens e bens de informática no âmbito do Programa de Inclusão Digital, por ocasião da implementação do, 361

[Lei $\mathrm{n}^{\circ}$ 12.431/2011]

aprovação de medidas tributárias de isenção da Contribuição para o PIS/Pasep e da Cofins para tablets no âmbito do Programa de Inclusão Digital, por ocasião da implementação do, 362

[Lei $\left.{ }^{\circ} 12.507 / 2011\right]$

\section{Propaganda}

(ver Publicidade)

Provimento de Capacidade de Satélite

(ver também Serviço de Valor Adicionado)

Contrato de Comercialização de Capacidade Espacial

, deve ser firmado no Brasil entre o representante legal da exploradora e a prestadora de serviço de telecomunicações, partes contratuais distintas, $\mathbf{3 7 6}$
[Súmula da ANATEL no ${ }^{\circ}$ 10, de 15 de março de 2011]

Provimento de Capacidade Espacial

(ver Provimento de Capacidade de Satélite)

Publicidade

Serviço de Comunicação Multimídia dever de dar publicidade aos resultados apresentados pelas prestadoras de SCM quanto aos indicadores definidos no RGQSCM, 372

[Resolução da ANATEL n ${ }^{\circ}$ 574, de 28 de outubro de 2011]

Serviço Móvel Pessoal

dever de dar publicidade aos resultados apresentados pelas prestadoras de SCM quanto aos indicadores definidos no RGQSCM, 372

[Resolução n ${ }^{\circ}$ 575/2011]

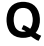

QoS

(ver Qualidade do Serviço)

Quadro de Atribuição de Faixas de Frequências

Aprovação do, 374

[Ato do Conselho Diretor da ANATEL $\left.\mathrm{n}^{\circ} 2.282 / 2011\right]$

Qualidade do Serviço, 343

Qualidade do Serviço

fixação de prazo até 31 de outubro de 2011 para adoção, pela Anatel, de padrões de qualidade para os serviços de telecomunicações que suportam o acesso à Internet em banda larga, inclusive parâmetros de velocidade efetiva de conexão mínima e média, disponibilidade do serviço, bem como critério de publicidade e transparência para aferição da qualidade percebida pelos usuários, 364 
[Decreto $\left.{ }^{\circ} 7.512 / 2011\right]$

Serviço de Comunicação Multimídia aprovação do Regulamento de Gestão da Qualidade do Serviço de Comunicação Multimídia, 372 [Resolução da ANATEL n 574 , de 28 de outubro de 2011]

Quanto à Perspectiva Convergente, 346

Quanto ao Gênero, 345

Quanto ao Regime Jurídico de Prestação, 345

$\mathbf{R}$

\section{Rádio-Táxi}

Regulamento sobre Canalização e Condições de Uso de Radiofrequências na Faixa de 148 $\mathrm{MHz}$ a $174 \mathrm{MHz}, 370$

[Resolução da ANATEL n ${ }^{\circ}$ 568/2011]

Radiodifusão, 351

Radiodifusão, 369

(ver também Radiodifusão Educativa) (ver também Sistema Brasileiro de Televisão Digital Terrestre)

[Resolução da ANATEL n ${ }^{\circ}$ 563/2011]

Serviço de Repetição de Televisão norma de procedimentos de autorização para execução do, 366-367

[Portaria MC n ${ }^{\circ} 498$, de 5 de dezembro de 2011] [Portaria $\mathrm{MC} \mathrm{n}^{\circ} 561$, de 22 de dezembro de 2011]

Serviço de Retransmissão de Televisão norma de procedimentos de autorização para execução do, 366 [Portaria MC n ${ }^{\circ} 498$, de 5 de dezembro de 2011]

Radiodifusão Comunitária, 352

Radiodifusão Educativa (ver também Educação)

(ver também Radiodifusão)

procedimento de apreciação de pedidos de outorga de concessão, permissão ou autorização para exploração de serviços de radiodifusão com fins exclusivamente educativos, 364-365 [Portaria MC no 256, de 6 de julho de 2011] [Portaria MC no 420/2011]

\section{Radiofreqüência}

(ver Espectro de Radiofreqüências)

Ramos Jurídicos Afins, 354

Reajuste Tarifário

(ver também Serviço Telefônico Fixo

Comutado)

(ver também Tarifa)

Regulamento sobre Critérios de

Reajuste das Tarifas das Chamadas

do Serviço Telefônico Fixo

Comutado (STFC) envolvendo acessos do Serviço Móvel Pessoal (SMP)ou do Serviço Móvel Especializado (SME) aprovação do, 372 [Resolução da ANATEL 576/2011]

\section{Receita Federal}

utilização da faixa de $148 \mathrm{MHz}$ a 174 $\mathrm{MHz}, 370$

\section{Recurso}

[Resolução da ANATEL nº 568/2011]

Processo Administrativo

não cabe recurso contra ato administrativo que determine ou formalize a instauração de processo administrativo sancionador, 376

[Súmula da ANATEL no 12, de 19 de dezembro de 2011]

Regulamento de Acompanhamento

e Controle das Obrigações de Universalização do STFC possibilidade de prorrogação de prazos por ato do Conselho Diretor da Anatel, 370

[Resolução da ANATEL n ${ }^{\circ}$ 569/2011] prorrogação de prazos referentes a campanhas de divulgação e divulgação a órgãos públicos, $\mathbf{3 7 0}$

[Resolução da ANATEL nº 569/2011] 
Regulamento de Gestão da Qualidade da Prestação do Serviço Móvel Pessoal aprovação do, $\mathbf{3 7 2}$

[Resolução no 575/2011]

Regulamento de Gestão de Qualidade, 372

[Resolução da ANATEL n ${ }^{\circ}$ 574, de 28 de outubro de 2011]

Regulamento de Gestão de Qualidade do Serviço de Comunicação Multimídia aprovação do, 372

[Resolução da ANATEL n ${ }^{\circ} 574$, de 28 de outubro de 2011]

Regulamento do Serviço do Rádio do Cidadão aprovação do, $\mathbf{3 7 3}$

[Resolução da ANATEL n ${ }^{\circ}$ 578/2011]

Regulamento sobre Áreas Locais para o STFC

aprovação do, $\mathbf{3 6 7}$

[Resolução da ANATEL n 560/2011]

Regulamento sobre Canalização e Condições de Uso de Radiofrequências na Faixa de 148 MHz a 174 MHz, 370

[Resolução da ANATEL n ${ }^{\circ}$ 568/2011]

Regulamento sobre Condições de Uso de Radiofrequiências nas Faixas de 25,35 GHz a $28,35 \mathrm{GHz}$, $29,10 \mathrm{GHz}$ a $29,25 \mathrm{GHz}$ e 31,00 GHz a $31,30 \mathrm{GHz}$ aprovação do, 368

[Resolução da ANATEL n ${ }^{\circ}$ 561/2011]

Regulamento sobre Critérios de Reajuste das Tarifas das Chamadas do Serviço Telefônico Fixo Comutado (STFC) envolvendo acessos do Serviço Móvel Pessoal (SMP)ou do
Serviço Móvel Especializado (SME) aprovação do, $\mathbf{3 7 2}$

[Resolução da ANATEL 576/2011]

Regumento para definição de formas e tolerâncias para dados geodésicos fornecidos à Anatel aprovação do, $\mathbf{3 7 1}$

[Resolução da ANATEL n 571/2011]

Relatório Anual

Relatório Anual Anatel 2010, 376

[Relatório Anual da ANATEL 2010]

Representante Legal

Exploradora de Satélite Estrangeiro requisitos para constituição de representante legal da, $\mathbf{3 7 6}$

[Súmula da ANATEL no ${ }^{\circ}$, de 15 de março de 2011]

Retransmissão de TV

(ver Serviço de Retransmissão de Televisão)

Revisão Quinquenal

Concessão

prorrogação da data da primeira revisão quinquenal dos contratos de concessão de STFC pós renovação, 369

[Resolução da ANATEL nº 565/2011]

RGQ-SMP, 372

[Resolução n 575/2011]

RpTV

(ver Serviço de Repetição de Televisão)

RTV

(ver Serviço de Retransmissão de Televisão)

Rural, 364

[Decreto $\left.{ }^{\circ} 7.512 / 2011\right]$

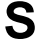

SAC 
(ver Serviço de Atendimento ao Consumidor)

Sanção, 376

[Súmula da ANATEL no 12, de 19 de dezembro de 2011]

Súmula $\mathrm{n}^{\circ} 12$

não cabe recurso contra ato administrativo que determine ou formalize a instauração de processo administrativo sancionador, 376

[Súmula da ANATEL no ${ }^{\circ}$ 12, de 19 de dezembro de 2011]

Satélite, 336, 368, 369, 371

(ver também Órbita)

[Resolução da ANATEL n ${ }^{\circ}$ 563/2011]

[Resolução da ANATEL n ${ }^{\circ}$ 572, de 28 de setembro de 2011]

Serviço Limitado Privado destinação da faixa de $26,55 \mathrm{GHz}$ a $26,85 \mathrm{GHz}$ ao SLP em aplicações de exploração da Terra por satélite, compartilhada com o STFC e o SCM, 368

[Resolução da ANATEL n ${ }^{\circ}$ 561/2011]

Satélite Estrangeiro, 376

(ver também Exploradora de Satélite Estrangeiro)

[Súmula da ANATEL no 10, de 15 de março de 2011]

Exploradora de Satélite Estrangeiro requisitos para constituição de representante legal da, $\mathbf{3 7 6}$

[Súmula da ANATEL n ${ }^{\circ}$, de 15 de março de 2011]

Satélite Geoestacionário

Antena para Estações Terrenas norma para certificação e homologação de, 371

[Resolução da ANATEL n ${ }^{\circ} 572$, de 28 de setembro de 2011]

SBTVD-T

(ver Sistema Brasileiro de Televisão SCM (ver Serviço de Comunicação Multimídia)

Serviço Auxiliar de Radiodifusão

e Correlatos (SARC), 353

Serviço de Acesso Condicionado, 354

Serviço de Acesso Condicionado

instituição do, 362

[Lei ${ }^{\circ}$ 12.485/2011]

Serviço de Atendimento ao

Consumidor

(ver também Centro de Atendimento)

(ver também Centro de Atendimento

(Indicadores de Qualidade do

STFC))

(ver também Centro de Atendimento

(Serviço Móvel Pessoal))

(ver também Centro de Atendimento

(Serviços de Televisão por

Assinatura))

(ver também Centro de Atendimento

para Intermediação da

Comunicação a Portadores de

Necessidades Especiais)

Serviço Móvel Pessoal

direito do consumidor de acesso ao conteúdo das gravações das chamadas por ele efetuadas à central de informação e de atendimento ao usuário da prestadora, 370

[Resolução da ANATEL nº 567/2011]

Serviço Telefônico Fixo Comutado

direito do consumidor de acesso ao conteúdo das gravações das chamadas por ele efetuadas à central de informação e de atendimento ao usuário da prestadora, 370

[Resolução da ANATEL no 567/2011]

Televisão por Assinatura (Gênero)

direito do consumidor de acesso ao conteúdo das gravações das chamadas por ele efetuadas à central de informação e de 
atendimento ao usuário da prestadora, 370

[Resolução da ANATEL n ${ }^{\circ}$ 567/2011]

\section{Serviço de Comunicação \\ Multimída (SCM), 349 \\ Serviço de Comunicação \\ Multimídia}

Metas de Qualidade

aprovação do Regulamento de

Gestão da Qualidade do Serviço

de Comunicação Multimídia, 372

[Resolução da ANATEL no 574 , de 28 de outubro de 2011]

Regulamento de Gestão de Qualidade do Serviço de Comunicação Multimídia aprovação do, 372

[Resolução da ANATEL n ${ }^{\circ}$ 574, de 28 de outubro de 2011]

Regulamento sobre Condições de Uso de Radiofrequiências nas Faixas de $25,35 \mathrm{GHz}$ a $28,35 \mathrm{GHz}, 29,10 \mathrm{GHz}$ a $29,25 \mathrm{GHz}$ e $31,00 \mathrm{GHz}$ a 31,30 $\mathrm{GHz}$

destinação da faixa de $26,55 \mathrm{GHz}$ a $26,85 \mathrm{GHz}$ ao SLP em aplicações de exploração da Terra por satélite, compartilhada com o STFC e o SCM, 368

[Resolução da ANATEL n 561/2011]

Serviço de Conexão à INTERNET como serviço de valor adicionado, $\mathbf{3 6 5}$

[Resolução ${ }^{\circ} 4$, de 16 de setembro de 2011]

Serviço de Distribuição de Sinais de Televisão e de Áudio por Assinatura Via Satélite

Serviço de Acesso Condicionado condições de adequação dos termos de autorização para as prestadoras de DTH à disciplina legal do, $\mathbf{3 6 2}$ [Lei ${ }^{\circ}$ 12.485/2011]

\section{Serviço de Distribuição de Sinais Multiponto Multicanal}

Autorização modelo de termo de autorização do MMDS, 375

[Ato do Conselho Diretor da ANATEL $n^{\circ} 5.156$, de 22 de julho de 2011]

Termo de Autorização

modelo de termo de autorização do MMDS, 375

[Ato do Conselho Diretor da ANATEL $n^{\circ}$ 5.156, de 22 de julho de 2011]

Serviço de Distribuição de Sinais

Multiponto Multicanal

Serviço de Acesso Condicionado condições de adequação dos termos de autorização e dos atos de autorização de uso de radiofrequência das prestadoras do MMDS à disciplina legal do, 362

[Lei ${ }^{\circ}$ 12.485/2011]

Serviço de Emergência, 369

(ver também Serviço Público de Emergência)

[Resolução da ANATEL n ${ }^{\circ}$ 564/2011]

Serviço de Interesse Coletivo

Artista

vedação de contratação de talentos artísticos nacionais de qualquer natureza, inclusive direitos sobre obras de autores nacionais por parte de prestadora de serviços de telecomunicações de interesse coletivo, $\mathbf{3 6 2}$

[Lei ${ }^{\circ} 12.485 / 2011$ ]

Direito de Exploração de Imagem vedação de aquisição ou de financiamento de aquisição de direitos de exploração de imagens de eventos de interesse nacional por parte de prestadora de serviços de telecomunicações de interesse coletivo, $\mathbf{3 6 2}$

[Lei ${ }^{\circ}$ 12.485/2011]

Serviço de Radiodifusão de Sons e Imagens 
(ver Radiodifusão)

Serviço de Radiodifusão por Satélite

destinação de faixas para serviços de telecomunicações que utilizem capacidade espacial, 369

[Resolução da ANATEL n 563/2011]

Serviço de Radiodifusão Sonora

(ver Radiodifusão)

Serviço de Radiotáxi, 353

Serviço de Repetição de Televisão

norma de procedimentos de autorização para execução do, 366367

[Portaria $\mathrm{MC}^{\circ}{ }^{\circ} 48$, de 5 de dezembro de 2011] [Portaria $\mathrm{MC} \mathrm{n}^{\circ}$ 561, de 22 de dezembro de 2011]

Serviço de Retransmissão de Televisão

norma de procedimentos de autorização para execução do, 366367

[Portaria $\mathrm{MC} \mathrm{n}^{\circ} 498$, de 5 de dezembro de 2011] [Portaria $\mathrm{MC} \mathrm{n}^{\circ} 561$, de 22 de dezembro de 2011]

Serviço de Telefonia Rural, 354

Serviço de Telefonia Rural

Regulamento sobre Canalização e

Condições de Uso de

Radiofrequências na Faixa de 148

$\mathrm{MHz}$ a $174 \mathrm{MHz}, 370$

[Resolução da ANATEL nº 568/2011]

\section{Serviço de TV a Cabo}

Serviço de Acesso Condicionado condições de adequação dos atos de outorga de concessão e respectivos contratos da TV a Cabo à disciplina legal do, $\mathbf{3 6 2}$

[Lei $n^{\circ}$ 12.485/2011]

Serviço de Valor Acrescentado (ver Serviço de Valor Adicionado)

Serviço de Valor Acrescido

(ver Serviço de Valor Adicionado)

Serviço de Valor Adicionado, 345

Serviço de Valor Adicionado (ver também INTERNET)

(ver também Provimento de Capacidade de Satélite)

Serviço de Conexão à INTERNET como serviço de valor adicionado, 365

[Resolução no 4 , de 16 de setembro de 2011]

Serviço Especial de TV por Assinatura

(ver Televisão por Assinatura (Espécie de Serviço Especial))

Serviço Limitado, 345

Serviço Limitado Privado, 345, 353

Serviço Limitado Privado

Regulamento sobre Canalização e

Condições de Uso de

Radiofrequências na Faixa de 148 $\mathrm{MHz}$ a $174 \mathrm{MHz}, 370$

[Resolução da ANATEL nº 568/2011]

Regulamento sobre Condições de Uso de Radiofrequiências nas Faixas de $25,35 \mathrm{GHz}$ a $28,35 \mathrm{GHz}, 29,10 \mathrm{GHz}$ a $29,25 \mathrm{GHz}$ e $31,00 \mathrm{GHz}$ a 31,30 $\mathrm{GHz}$

destinação da faixa de $26,55 \mathrm{GHz}$ a $26,85 \mathrm{GHz}$ ao SLP em aplicações de exploração da Terra por satélite, compartilhada com o STFC e o SCM, 368

[Resolução da ANATEL no 561/2011]

\section{Serviço Móvel Especializado}

Regulamento sobre Critérios de Reajuste das Tarifas das Chamadas do Serviço Telefônico Fixo Comutado (STFC) envolvendo acessos do Serviço Móvel Pessoal (SMP)ou do Serviço Móvel Especializado (SME) aprovação do, $\mathbf{3 7 2}$

[Resolução da ANATEL 576/2011]

Serviço Móvel Marítimo, 353 Serviço Móvel Marítimo

Regulamento sobre Canalização e Condições de Uso de 
Radiofrequências na Faixa de 148

$\mathrm{MHz}$ a $174 \mathrm{MHz}, 370$

[Resolução da ANATEL no ${ }^{\circ}$ 68/2011]

Serviço Móvel Pessoal (SMP), 349

Serviço Móvel Pessoal

Metas de Qualidade

aprovação do Regulamento de Gestão da Qualidade da Prestação do Serviço Móvel Pessoal, 372

[Resolução $n^{\circ}$ 575/2011]

Regulamento de Gestão da Qualidade da Prestação do Serviço Móvel Pessoal

aprovação do, $\mathbf{3 7 2}$

[Resolução n 575/2011]

Regulamento sobre Critérios de Reajuste das Tarifas das Chamadas do Serviço Telefônico Fixo Comutado (STFC) envolvendo acessos do Serviço Móvel Pessoal (SMP)ou do Serviço Móvel Especializado (SME)

aprovação do, 372

[Resolução da ANATEL 576/2011]

Serviço Prestado em Regime Público, 345

Serviço Público de Emergência

(ver também Serviço de Emergência)

Mensagem de Texto

regulamentação do seu envio aos serviços públicos de emergência, 369

[Resolução da ANATEL no 564/2011]

Serviço Rádio do Cidadão, 351

Serviço Telefônico Fixo Comutado

(STFC), 346

Serviço Telefônico Fixo Comutado,

346

(ver também Reajuste Tarifário)

(ver também Serviço Telefônico Fixo

Comutado Destinado ao Uso do

Público em Geral)

Área de Tarifação

sua alteração para o município de

Altamira do Paraná, 373
[Resolução da ANATEL n ${ }^{\circ}$ 577, de 24 de novembro de 2011]

Inventário de Bens Reversíveis determinação de 2011 à Brasil Telecom S/A para que efetuasse o inventário físico do seu patrimônio e dos seus bens reversíveis, $\mathbf{3 7 3}$

[Ato da Superintendência de Radiofrequencia e Fiscalização e da Superintendência de Serviços Públicos da ANATEL $n^{\circ}$ 160/ 2011]

determinação de 2011 à Empresa Brasileira de Telecomunicações S.A. para que efetuasse o inventário físico de todos os seus bens e dos bens reversíveis, 374

[Ato da Superintendência de Radiofrequencia e Fiscalização e da Superintendência de Serviços Públicos da ANATEL n ${ }^{\circ}$ 162/2011]

determinação de 2011 à Telemar Norte Leste S.A. para que efetuasse o inventário físico de todos os seus bens e dos bens reversíveis, 374

[Ato da Superintendência de Radiofrequencia e Fiscalização e da Superintendência de Serviços Públicos da ANATEL n ${ }^{\circ}$ 161/2011]

Onerosidade

inclusão, na base de cálculo do ônus contratual previsto nos contratos de concessão do STFC de 2006/2010, das receitas de interconexão, PUC e serviços adicionais e receitas operacionais inerentes ao STFC, 376

[Súmula da ANATEL no 11, de 17 de novembro de 2011]

Regulamento sobre Áreas Locais para o STFC

aprovação do, 367

[Resolução da ANATEL no 560/2011]

Regulamento sobre Canalização e

Condições de Uso de 
Radiofrequências na Faixa de 148 $\mathrm{MHz}$ a $174 \mathrm{MHz}, 370$

[Resolução da ANATEL nº 568/2011]

Regulamento sobre Critérios de

Reajuste das Tarifas das Chamadas do Serviço Telefônico Fixo Comutado (STFC) envolvendo acessos do Serviço Móvel Pessoal (SMP)ou do Serviço Móvel Especializado (SME) aprovação do, 372

[Resolução da ANATEL 576/2011]

Zona Rural

definição dos princípios regentes da licitação das subfaixas de radiofrequência de $451 \mathrm{MHz}$ a $458 \mathrm{MHz}$ e de $461 \mathrm{MHz}$ a 468 $\mathrm{MHz}, 364$

[Decreto $\left.\mathrm{n}^{\circ} 7.512 / 2011\right]$

\section{Serviço Telefônico Fixo Comutado} Destinado ao Uso do Público em Geral, 372

(ver também Serviço Telefônico Fixo Comutado)

[Resolução da ANATEL n ${ }^{\circ}$ 573, de 10 de outubro de 2011]

Regulamento sobre Condições de Uso de Radiofrequiências nas Faixas de $25,35 \mathrm{GHz}$ a $28,35 \mathrm{GHz}, 29,10 \mathrm{GHz}$ a $29,25 \mathrm{GHz}$ e $31,00 \mathrm{GHz}$ a 31,30 $\mathrm{GHz}$

destinação da faixa de $26,55 \mathrm{GHz}$ a $26,85 \mathrm{GHz}$ ao SLP em aplicações de exploração da Terra por satélite, compartilhada com o STFC e o SCM, 368

[Resolução da ANATEL n ${ }^{\circ}$ 561/2011]

Serviços no Setor de Telecomunicações, 346

Sigilo

Procedimento Administrativo para Apuração de Descumprimento de Obrigações (Agência Nacional de Telecomunicações)

publicidade dos Pados da Anatel, 375
[Portaria ANATEL n ${ }^{\circ}$ 941/2011]

Processo Administrativo

disciplina legal do acesso a informações, 363

[Lei $\mathrm{n}^{\circ} 12.527$, de 18 de novembro de 2011]

publicidade dos Pados da Anatel, 375

[Portaria ANATEL n ${ }^{\circ}$ 941/2011]

Sigilo em Telecomunicações, 344

Sistema Brasileiro de Defesa da

Concorrência

(ver também Conselho Administrativo

de Defesa Econômica)

lei regente, $\mathbf{3 6 3}$

[Lei ${ }^{\circ} 12.529$, de 30 de novembro de 2011]

Sistema Brasileiro de Televisão Digital Terrestre (ver também Radiodifusão) (ver também TV Digital)

Padrão ISDB-T adoção pelo Brasil do, 366 [Portaria MC no 491/011]

Sistema TELEBRÁS

(ver Telecomunicações Brasileiras S.A.)

SLP

(ver Serviço Limitado Privado)

SME

(ver Serviço Móvel Especializado)

SMM

(ver Serviço Móvel Marítimo)

SMP

(ver Serviço Móvel Pessoal)

STFC

(ver Serviço Telefônico Fixo Comutado)

Subsídio Cruzado

sua vedação em atividades de produção, programação, empacotamento ou distribuição de comunicação audiovisual de acesso condicionado, $\mathbf{3 6 2}$

[Lei n ${ }^{\circ}$ 12.485/2011] 


\section{Súmula $\mathbf{n}^{0} 11$}

inclusão, na base de cálculo do ônus contratual previsto nos contratos de concessão do STFC de 2006/2010, das receitas de interconexão, PUC e serviços adicionais e receitas operacionais inerentes ao STFC, 376

[Súmula da ANATEL n ${ }^{\circ}$ 11, de 17 de novembro de 2011]

\section{Súmula $\mathrm{n}^{0} 12$}

não cabe recurso contra ato administrativo que determine ou formalize a instauração de processo administrativo sancionador, 376

[Súmula da ANATEL no 12, de 19 de dezembro de 2011]

SVA

(ver Serviço de Valor Adicionado)

T

\section{Tablet}

Programa Nacional de Banda Larga aprovação de medidas tributárias de isenção da Contribuição para o PIS/Pasep e da Cofins para tablets no âmbito do Programa de Inclusão Digital, por ocasião da implementação do, $\mathbf{3 6 2}$

[Lei $\mathrm{n}^{\circ}$ 12.507/2011]

\section{Tarifa}

(ver também Preço Público)

(ver também Reajuste Tarifário)

Liberdade Tarifária

sua implantação e acompanhamento no STFC Longa Distância Internacional, $\mathbf{3 7 2}$

[Resolução da ANATEL n 573 , de 10 de outubro de 2011]

\section{Tarifas Fixadas}

Aumento Arbitrário de Lucros causa de restabelecimento do regime de Tarifas Fixadas no STFC, Modalidade Longa Distância Internacional, $\mathbf{3 7 2}$
[Resolução da ANATEL n ${ }^{\circ}$ 573, de 10 de outubro de 2011]

Taxas de fiscalização de instalação

\section{e funcionamento}

Não incidência

ajuste de informações de coordenadas geodésicas não exige novo licenciamento ou pagamento de taxas, desde que não associada a uma real mudança do local de instalação, 371

[Resolução da ANATEL n 571/2011]

\section{Tecnologia Nacional}

sua preferência quando da aquisição de equipamentos e materiais vinculados à execução das obrigações estabelecidos no Plano Geral de Metas de Universalização, 364

[Decreto $\left.\mathrm{n}^{\circ} 7.512 / 2011\right]$

Tecnologias da Informação e

\section{Comunicação, 364}

[Portaria MC n 376/2011]

Tecnologias da Informação e Comunicação

(ver também Tecnologias de Informação e Comunicação)

sua apropriação pela gestão pública local e pela população como objetivo do Projeto de Implantação e Manutenção das Cidades Digitais, 364

[Portaria MC no 376/2011]

Tecnologias de Informação e Comunicação, 364

(ver também Tecnologias da Informação e Comunicação)

[Portaria MC n ${ }^{\circ}$ 376/2011]

\section{TELEBRÁS}

(ver Telecomunicações Brasileiras S.A.)

Telecomunicações Brasileiras S.A.

Cidades Digitais

responsabilidade da Telebrás pelo planejamento, elaboração de editais, acompanhamento e 
avaliação da implementação da infraestrutura de conexão das, 364

[Portaria MC n $\left.{ }^{\circ} 376 / 2011\right]$

Programa de Dispêndios Globais

(Empresas Estatais Federais)

PDG para 2012, 364

[Decreto $\left.n^{\circ} 7.628 / 2011\right]$

Telecomunicações de São Paulo S.A

anuência prévia à incorporação da

Vivo pela Telesp, 375

[Ato do Conselho Diretor da ANATEL $\left.n^{\circ} 5.703 / 2011\right]$

\section{Telefônica}

(ver também Operadora de

Telecomunicações)

Vivo Participações S/A

anuência prévia à incorporação da

Vivo pela Telesp, 375

[Ato do Conselho Diretor da ANATEL $\left.\mathrm{n}^{\circ} 5.703 / 2011\right]$

anuência prévia à reestruturação societária decorrente da aquisição da Vivo pela Telefônica, 374

[Ato do Conselho Diretor da ANATEL $\left.n^{\circ} 1.970 / 2011\right]$

TELEMAR NORTE LESTE S.A.

Bem Reversível

determinação de 2011 à Telemar Norte Leste S.A. para que efetuasse o inventário físico de todos os seus bens e dos bens reversíveis, 374

[Ato da Superintendência de Radiofrequencia e Fiscalização e da Superintendência de Serviços Públicos da ANATEL $n^{\circ}$ 161/2011]

\section{TELESP, 375}

[Ato do Conselho Diretor da ANATEL ${ }^{\circ}$ 5.703/2011]

Vivo Participações S/A

anuência prévia à incorporação da

Vivo pela Telesp, 375

[Ato do Conselho Diretor da ANATEL $\left.\mathrm{n}^{\circ} 5.703 / 2011\right]$

\section{Televisão Digital}

(ver TV Digital)

Televisão por Assinatura (Espécie de Serviço Especial)

Serviço de Acesso Condicionado condições de adequação dos atos de autorização de uso de radiofrequência das prestadoras de TVA à disciplina legal do, $\mathbf{3 6 2}$ [Lei ${ }^{\circ}$ 12.485/2011]

Termo de Autorização

Serviço de Distribuição de Sinais Multiponto Multicanal

modelo de termo de autorização para o, 375

[Ato do Conselho Diretor da ANATEL $\mathrm{n}^{\circ}$ 5.156, de 22 de julho de 2011]

Título Oneroso

(ver Onerosidade)

Transparência

disciplina legal do acesso a informações, 363

[Lei ${ }^{\circ} 12.527$, de 18 de novembro de 2011]

Procedimento Administrativo para Apuração de Descumprimento de Obrigações (Agência Nacional de Telecomunicações) publicidade dos Pados da Anatel, 375

[Portaria ANATEL n ${ }^{\circ}$ 941/2011]

\section{Tributação no Setor de} Telecomunicações, 338

\section{Trunking}

(ver Serviço Móvel Especializado)

TV a Cabo, 349

\section{TV Digital}

(ver também Sistema Brasileiro de Televisão Digital Terrestre)

Padrão ISDB-T adoção pelo Brasil do, 366

[Portaria MC n 491/011]

\section{TVA}


(ver Televisão por Assinatura (Espécie de Serviço Especial))

TVA (Serviço Especial de TV por Assinatura), 350

\section{U}

\section{Universalização}

Regulamento de Acompanhamento e Controle das Obrigações de Universalização do STFC

possibilidade de prorrogação de prazos por ato do Conselho Diretor da Anatel, 370

[Resolução da ANATEL nº 569/2011] prorrogação de prazos referentes a campanhas de divulgação e divulgação a órgãos públicos, 370

[Resolução da ANATEL no 569/2011]

Universalização e Massificação, 342

\section{Usuário / Consumidor, 360}

\section{V}

Valor Adicionado

(ver Serviço de Valor Adicionado)

Valor de Comunicação

(ver Valor de Comunicação (Serviço

Móvel Especializado))

(ver Valor de Comunicação (Serviço

Móvel Pessoal))

(ver Valor de Comunicação (Serviço

Telefônico Fixo Comutado))

Valor de Comunicação (Serviço

Móvel Especializado)

Regulamento sobre Critérios de Reajuste das Tarifas das Chamadas do Serviço Telefônico Fixo Comutado (STFC) envolvendo acessos do Serviço Móvel Pessoal (SMP)ou do Serviço Móvel Especializado (SME) aprovação do, $\mathbf{3 7 2}$

[Resolução da ANATEL 576/2011]
Valor de Comunicação (Serviço Móvel Pessoal)

Regulamento sobre Critérios de Reajuste das Tarifas das Chamadas do Serviço Telefônico Fixo Comutado (STFC) envolvendo acessos do Serviço Móvel Pessoal (SMP)ou do Serviço Móvel Especializado (SME) aprovação do, 372

[Resolução da ANATEL 576/2011]

Valor de Comunicação (Serviço Telefônico Fixo Comutado)

Regulamento sobre Critérios de Reajuste das Tarifas das Chamadas do Serviço Telefônico Fixo Comutado (STFC) envolvendo acessos do Serviço Móvel Pessoal (SMP)ou do Serviço Móvel Especializado (SME) aprovação do, 372

[Resolução da ANATEL 576/2011]

VC

(ver Valor de Comunicação (Serviço Telefônico Fixo Comutado))

VC-T

(ver Valor de Comunicação (Serviço Móvel Especializado))

Vivo Participações S/A

anuência prévia à incorporação da Vivo pela Telesp, $\mathbf{3 7 5}$

[Ato do Conselho Diretor da ANATEL $\left.\mathrm{n}^{\mathrm{o}} 5.703 / 2011\right]$

anuência prévia à reestruturação societária decorrente da aquisição da Vivo pela Telefônica, 374

[Ato do Conselho Diretor da ANATEL $\left.\mathrm{n}^{\circ} 1.970 / 2011\right]$

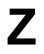

zona rural

(ver Rural)

Zona Rural

Banda Larga 
definição do princípio de atendimento para acesso à Internet em banda larga para escolas públicas rurais quando da licitação das subfaixas de radiofrequência de $451 \mathrm{MHz}$ a $458 \mathrm{MHz}$ e de $461 \mathrm{MHz}$ a 468 $\mathrm{MHz}, 364$

[Decreto $\left.{ }^{\circ} 7.512 / 2011\right]$

Escola Pública

definição do princípio de atendimento para acesso à Internet em banda larga para escolas públicas rurais quando da licitação das subfaixas de radiofrequência de $451 \mathrm{MHz}$ a $458 \mathrm{MHz}$ e de $461 \mathrm{MHz}$ a 468 $\mathrm{MHz}, 364$

[Decreto $\mathrm{n}^{\circ}$ 7.512/2011]

Universalização

dever de licitação, por parte da Anatel, até 30 de abril de 2012, de autorização de uso de radiofrequência de $451 \mathrm{MHz}$ a $458 \mathrm{MHz}$ e de $461 \mathrm{MHz}$ a 468 $\mathrm{MHz}$ para fins de ampliação da penetração dos serviços de telecomunicações de voz e de dados, 364

[Decreto $\left.\mathrm{n}^{\mathrm{o}} 7.512 / 2011\right]$ 
